\title{
ANÁLISE DA PARTICIPAÇÃO DO BRASIL NO MERCADO INTERNACIONAL DE AÇÚCAR
}

\author{
SÍLVIA HELENA GALVÃo DE MIRANDA STALDER
}

Engenheira Agrônoma

Orientadora: Prof. ${ }^{\text {a }}$ Dr. ${ }^{-a}$ HELOISA LEE BURNQUIST

Dissertação apresentada à Escola Superior de Agricultura “Luiz de Queiroz”, da Universidade de São Paulo, para obtenção do título de Mestre em Ciências. Área de Concentração: Economia Aplicada.

\author{
PIRACICABA \\ Estado de São Paulo - Brasil
}

Fevereiro - 1997 
Dados Internacionais de Catalogação na Publicação (CIP) DIVISÃo DE BIBLIOTECA E DOCUMENTAÇÃO - Campus "Luiz de Queiroz"/USP

Stalder, Silvia Helena Galvão de Miranda

Análise da participação do Brasil no mercado internacional de açúcar / Silvia Helena Galvão de Miranda Stalder. - - Piracicaba, 1997.

121 p. : il.

Dissertação (mestrado) - Escola Superior de Agricultura Luiz de Queiroz, 1997.

Bibliografia.

1. Açúcar - Mercado externo - Brasil 2. Comércio exterior - Análise - Brasil 3. Exportação agricola - Brasil I. Título 


\title{
ANÁLISE DA PARTICIPAÇÃO DO BRASIL NO MERCADO INTERNACIONAL DE AÇÚCAR
}

\author{
SÍLVIA HELENA GALVÃO DE MIRANDA STALDER
}

Aprovada em 31.03.1997

Comissão julgadora:

Prof. ${ }^{\underline{a}}$ Dr. ${ }^{\mathrm{a}}$ Heloisa Lee Burnquist

ESALQ/USP

Prof. Dr. Geraldo Sant'Ana de Camargo Barros

ESALQ/USP

Prof. Dr. Plínio M. Nastari

FGV/SP

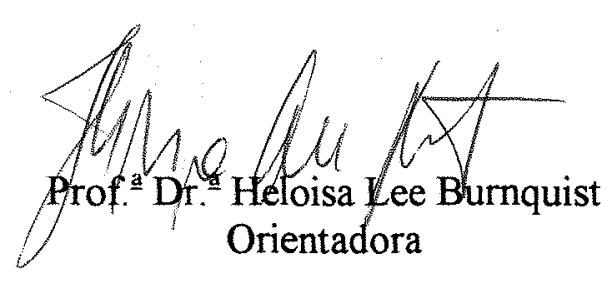


Aos meus pais,

Maria Inês e Eugênio,

\section{Ofereço.}

Aos meus filhos,

Luiza Helena e Carlos

Dedico. 


\section{AGRADECIMENTOS}

À Professora Doutora Heloísa Lee Burnquist, pela orientação, pela amizade e pelo seu exemplo de dedicação e esforço.

Ao Professor Dr. Geraldo Sant'Ana de Camargo Barros, pela colaboração ao longo do desenvolvimento desta dissertação, contribuindo com a precisão de suas sugestões para o aperfeiçoamento da mesma.

Aos Professores Dr. Paulo Fernando Cidade de Araújo, Dra. Zilda Paes de Barros e Dr. Plínio M. Nastari, pelas críticas e sugestões que certamente enriqueceram este trabalho.

Ao Dr. Antônio Hermínio Pinazza e à Doutora Miriam Rumenos Piedade Bacchi, pela amizade com que me ajudaram.

Aos professores e funcionários do Departamento de Economia e Sociologia Rural da ESALQ/USP, pelo apoio;

Aos colegas do curso de pós-graduação, pelo companheirismo e, em especial, pelas amizades inestimáveis que cultivamos.

À Coordenadoria de Aperfeiçoamento de Ensino (CAPES) pelo auxilio financeiro, que possibilitou minha participação no curso de Mestrado;

A todos que, direta e indiretamente, contribuíram para a realização deste trabalho. 


\section{SUMÁRIO}

Página

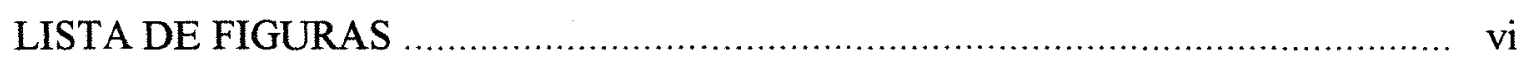

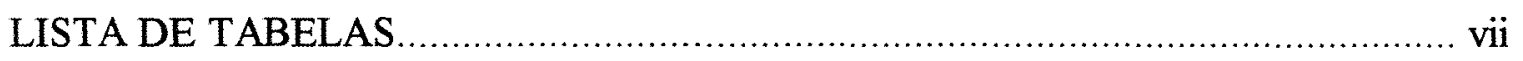

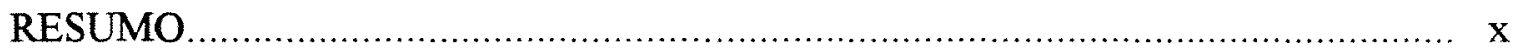

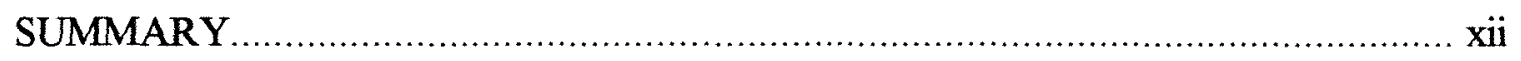

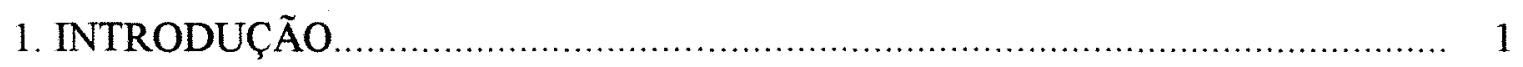

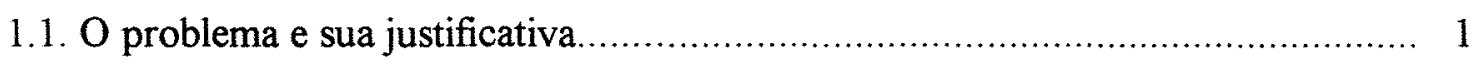

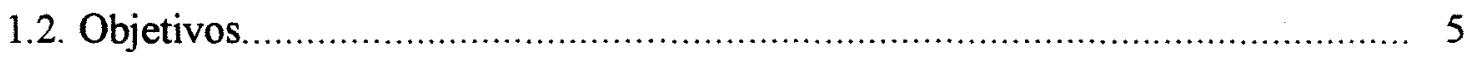

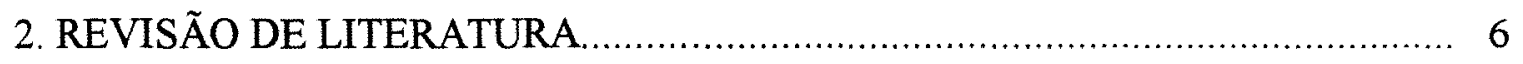

2.1. Caracterização do setor sucroalcooleiro no Brasil................................. 6

2.2. Panorama do mercado exportador brasileiro de açúcar ........................... 13

2.3. O mercado internacional do açúcar ................................................. 20

2.4. Fatores determinantes das exportações de açúcar pelo Brasil........................ 29

2.5. A diferenciação de produtos no comércio internacional e

a definição de competitividade ............................................................ 33

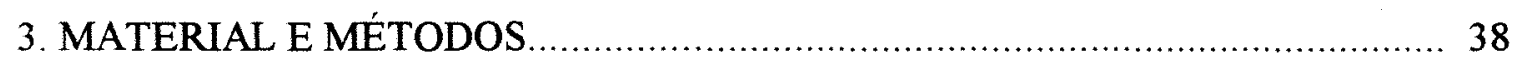

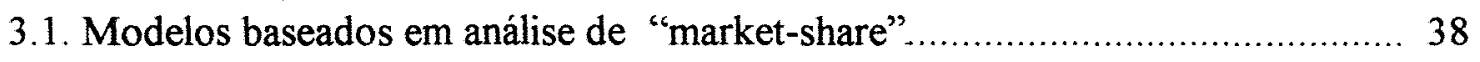

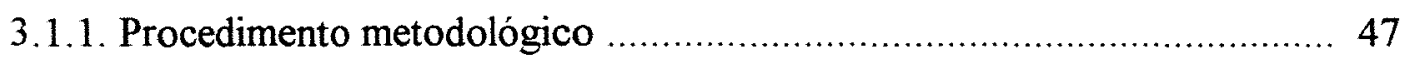

3.2. O modelo de Elasticidade de Substituição ................................... 53

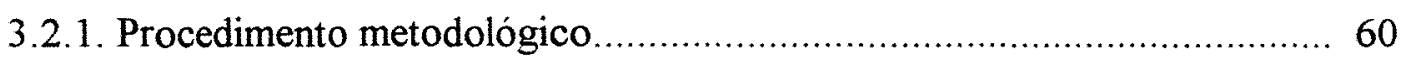




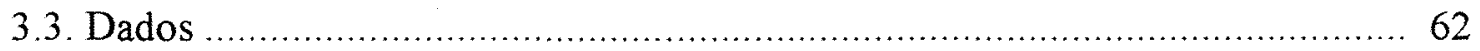

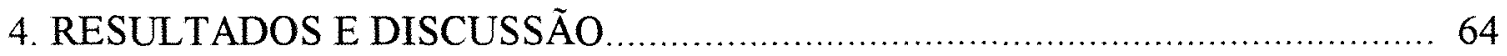

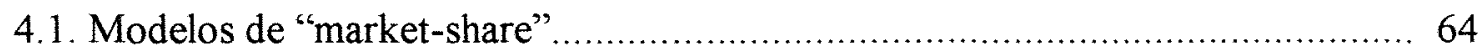

4.1.1. Análise de "market-share" - O crescimento das exportações

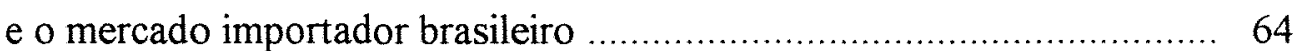

4.1.2. Análise de "market-share"- Crescimento das exportações e

Grau de Preferência .............................................................. 83

4.2. Modelo de elasticidade de substituição .......................................... 99

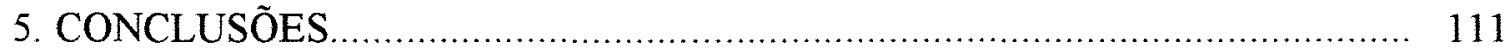

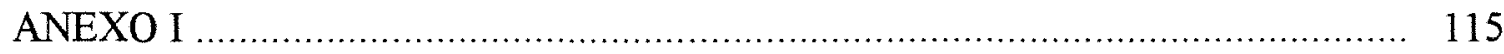

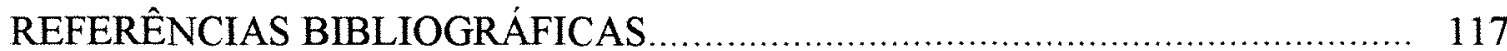




\section{LISTA DE FIGURAS}

Página

1 Exportações brasileiras de açúcar, em toneladas, no periodo de 1979 a 1996. Fonte: Carteira de Comércio (CACEX), SECEX e Plano de Safra 1996/97.

2 Participação das exportações brasileiras de açúcar em relação ao total mundial comercializado. 1979-1994. Fonte: Elaborado a partir de dados da FAO Trade Yearbook, 1979/1994.

3 Preço do açúcar demerara - contrato $\mathrm{n}^{\circ} 11$ de Nova Iorque, FOB, em portos do Caribe, em centavos de dólar por libra-peso; relação estoque/consumo de açúcar. Fonte de dados: Sugar and Sweetener/ USDA (1994)

4 Produção e exportação brasileira de açúcar,toneladas em equivalente demerara. 1979-1995. Fonte: Elaborado a partir de dados da FAO (SOFA95) e Agroanalysis (1995)

5 Evolução das exportações brasileiras de açúcar cristal, demerara e refinado, em toneladas, para o periodo de 1979 a 1995. Fonte: Elaborado com dados da CACEX/SECEX.

6 Produção, consumo, exportação, estoque final e preço de açúcar no mercado mundial, em milhões de toneladas e em centavos de dólar por libra-peso, e relação estoque/consumo em \% ( Dados da Sugar and Sweetener/USDA, 1993/1994).

7 Preços do açúcar demerara no mercado mundial livre (Preço ISA, International Sugar Agreement, uma média do spot do contrato $\mathrm{n}^{\circ}-11$ de Nova Iorque e do preço FOB diário de Londres, para os portos do Caribe. 1960/1992. Fonte: Abbott (1990) 


\section{LISTA DE TABELAS}

Página

1 Produção no setor sucroalcooleiro brasileiro para o ano safra $1996 / 97$.................. 3

2 Quantidade de cana-de-açúcar moída, produção de açúcar total (em equivalente demerara) e de álcool (anidro e hidratado), na região Norte-Nordeste, Centro-Sul e no Brasil. Safras 1985/86 a $1996 / 97$

3 Exportações brasileiras de açúcar total (em equivalente demerara) por região de origem -1985/86 a 1996/97

4 Taxas de crescimento das exportações do Brasil discriminadas por tipo de açúcar para o período 1979-1994.

5 Principais países produtores e consumidores de açúcar. Média dos últimos anos para quantidades produzidas e consumidas ( em açúcar bruto)

6 Principais paises exportadores e importadores de açúcar e volumes comercializados no mercado mundial, 1990-1994.

7 Elasticidades-preço da demanda e da oferta de exportação brasileira de açúcar segundo vários autores.

8 Exportação média anual brasileira e mundial de açúcar nos subperíodos 1979/84 e 1985/89, em toneladas; e participação do Brasil nas quantidades importadas de açúcar pelos seus principais importadores

e por continentes. 66

9 Componentes do ganho/perda nas exportações brasileiras de açúcar. 1979/84 a 1985/89 
10 Exportação média anual brasileira e mundial de açúcar nos subperíodos 1985/89 e 1990/94 em toneladas; participação do Brasil nos volumes importados pelos seus principais importadores e por continentes.

11 Componentes do ganho/perda nas exportações brasileiras de açúcar. $1985 / 89$ - 1990/94

12 Exportação média anual brasileira e mundial de açúcar nos subperiodos 1979/84 e 1990/94 em toneladas; e participação do Brasil nas quantidades importadas de açúcar pelos seus principais importadores e por continentes.

13 Componentes do ganho/perda nas exportações brasileiras de açúcar. 1979/84 A 1990/94

14 Média anual da importação mundial de açúcar e da exportação brasileira, nos subperíodos 1979/84 e 1985/89, em toneladas; e participação do Brasil no total importado por países selecionados e e por grupos de países.

15 Componentes do ganho/perda nas exportações brasileiras, no periodo $1979 / 84$ - 1985/89.

16 Média anual da importação mundial de açúcar e da exportação brasileira, nos subperíodos 1979/84 e 1985/89, em toneladas; e participação do Brasil no total importado por países selecionados e por grupos de paises

17 Componentes do ganho/perda nas exportações brasileiras, no periodo $1985 / 89$ - 1990/94

18 Média anual da importação mundial de açúcar e da exportação brasileira, nos subperíodos 1979/84 e 1990/94, em toneladas; e participação do Brasil no total importado por países selecionados e 


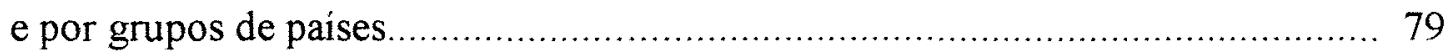

19 Componentes do ganho/perda nas exportações brasileiras, no periodo $1979 / 84-1990 / 94$

20 Taxas de crescimento das exportações e importações mundiais de açúcar total para mercados selecionados; e participação média dos países no mercado mundial. 1979-1994.

21 Participação dos paises exportadores selecionados nas exportações mundiais $\left(\mathrm{x}_{\mathrm{i}}\right)$, Índice de Concentração Geográfica das exportações, e participação dos países importadores no total vendido pelos exportadores $\left(\mathrm{m}_{\mathrm{ij}}\right)$

22 Participação dos paises importadores selecionados nas importações mundiais $\left(\mathrm{m}_{\mathrm{i}}\right)$, Índice de Concentração Geográfica das importações, e participação dos paises exportadores no total comprado pelos importadores $\left(\mathrm{x}_{\mathrm{ij}}\right)$

23 Grau de Preferência $\left(\mathrm{P}_{\mathrm{ij}}\right)$ entre países selecionados, importadores e exportadores de açúcar. 1982-1994.

24 Componentes do crescimento das exportações de açúcar dos países selecionados nos períodos 1982/84 - 1985/89 e 1985/89- 1990/94

25 Estimativas de elasticidade de substituição. Valor para o teste " $\mathrm{t}$ " de Student entre parênteses e Durbin -Watson. 1979 - 1994.

26 Estimativas de elasticidade de substituição para açúcar entre Brasil e os principais exportadores mundiais e coeficientes da variável defasada $(\gamma)$. Modelo com variável defasada de um período. Valor para o teste " $t$ " de Student entre parênteses.1979-1994. 


\title{
ANÁLISE DA PARTICIPAÇÃO DO BRASIL NO MERCADO INTERNACIONAL DO AÇÚCAR
}

\author{
Autora: Sílvia Helena Galvão de Miranda Stalder \\ Orientadora: Prof. ${ }^{\text {a }}$ Dr. ${ }^{-a}$ Heloísa Lee Burnquist
}

\section{RESUMO}

O objetivo principal desta dissertação foi o de analisar o padrão das exportações brasileiras de açúcar entre 1979 e 1994, bem como os fatores que influenciaram o desempenho dessas exportações e sua interação com os demais países, exportadores e importadores, que participam do mercado internacional de açúcar.

A importância deste assunto no contexto atual da economia brasileira relaciona-se à questão das novas políticas que vêm sendo adotadas para o setor sucroalcooleiro do País, e, consequentemente, às perspectivas que essas mudanças podem trazer para a evolução das exportações de açúcar.

Procedeu-se à descrição do panorama doméstico e internacional da produção e comercialização de açúcar, incluindo-se taxas de crescimento das exportações e importações dos países representativos no mercado mundial. Além disso, para a análise empírica foram utilizados dois modelos, o de "Market-Share" Constante e o de Elasticidade de Substituição no comércio internacional.

A análise de market-share foi baseada em um modelo apresentado por Rigaux (1971) que permite dividir o crescimento real das exportações de um pais em componentes denominados "tamanho de mercado", "distribuição do mercado importador" e "competitividade". A análise do "market-share" foi aplicada a dados do Brasil e permitiu discriminar seus principais importadores. Verificou-se que de 1979 a 1989, o Brasil perdeu participação no mercado mundial, o que pode ser explicado pela redução das exportações destinadas aos EUA e à ex-URSS. No restante do período analisado (1990-1994), essa tendência foi parcialmente revertida, havendo recuperação

no mercado norte-americano e expansão nos mercados da África, Ásia e no 
MERCOSUL. Contribuíram para esse resultado: efeitos positivos relativos a "tamanho de mercado" e "competitividade".

A segunda abordagem de "market-share", baseada em Konandreas \& Hurtado (1978), incluiu o efeito "estrutura de preferências", tendo sido aplicada a dados do Brasil, Cuba e Resto do Mundo. Os resultados desta análise confirmaram a recuperação do Brasil no mercado mundial, nos últimos cinco anos, devido aos efeitos positivos relacionados acima, ao efeito "distribuição do mercado importador" também favorável e um efeito "estrutura de preferências" negativo. Ressalta-se que o grau de preferência pelas exportações do País caiu bastante no mercado da ex-URSS.

No caso de Cuba, verificou-se que, praticamente, não houve alteração na preferência pelo seu açúcar por parte dos tradicionais importadores (ex-URSS, China e Japão), embora o total exportado tenha se reduzido. Os componentes "competitividade" e "distribuição do mercado importador" influenciaram negativamente a evolução das exportações cubanas. Os resultados não permitem concluir que o Brasil tenha se apropriado da parcela de mercado que Cuba perdeu nos últimos anos, quando se consideram seus principais importadores.

Os coeficientes de elasticidade de substituição foram estimados através de regressões simples, sendo que foram encontrados valores negativos e estatisticamente significativos para: Brasil/África do Sul (açúcar total; bruto); Brasil/França (bruto); Brasil/Filipinas (refinado) e Brasil/Alemanha (refinado). Isso indica que há substitutibilidade entre o açúcar exportado por esses países, e, portanto, competição entre os mesmos pelo mercado mundial. Os casos que apresentaram baixo grau de substituição, indicando a existência de diferenciação de produtos pelo mercado importador, resumem-se às relações: Brasil/Filipinas (açúcar total) e Brasil/Austrália (refinado). 


\title{
AN ANALYSIS OF BRAZILIAN PARTICIPATION ON THE INTERNATIONAL SUGAR MARKET
}

\author{
Author: Sílvia Helena Galvão de Miranda Stalder \\ Adviser: Professor Heloisa Lee Burnquist
}

\section{SUMMARY}

The main purpose of this dissertation was to analyze the pattern of Brazilian sugar exports between 1979 and 1994 as well as the factors that affected the export's performance together with its interaction to those of other countries, exporters and importers, that participate in the international sugar market.

The importance of the subject for the Brazilian economy is related to a current promotion of policy changes and their expected effects for the overall sugar and alcohol sector's performance along with the changes that may occur on Brazilian sugar exports.

A general description of the domestic and international sugar production and market characteristics is presented, including estimated growth rates for sugar exports and imports values of a set of countries that represent the international market. In addition, the study presents an empirical analysis based on a Constant-Market-Share model and on an Elasticity of Substitution model for international trade.

The market share analysis was conducted based on a model presented by Rigaux (1971) which allows the division of a country's actual export growth into market size, importer's market composition, and competitiveness components. This analysis involved Brazilian data and the identification of its major importers. The results have shown that Brazilian participation in the sugar world market has decreased between 1979 and 1989, which can be explained by a reduction of exports to the United States and former-Soviet Union markets. Along the period that follows, between 1990 and 1994, this trend has been reversed which is apparently explained by an increase in the United States' import demand for Brazilian sugar as well as an expansion of the imported sugar 
volume to Africa, Asia an to MERCOSUL countries. These results were explained by positive market size and competitiveness effects.

The second approach to the market share analysis was based upon a model developed by Konandreas \& Hurtado (1978) which incorporates preference structure effects and has been applied using export data for Brazil, Cuba and a set including the Rest of the World export data. The results of this analysis have sustained that Brazil's share in world market has been improved over the last years, corroborating the positives effects discussed above but bringing out a favorable importer market composition effect and a negative preference structure one. It is important to point out that Brazil's preference in former-Soviet Union market has fallen substantially.

Market-share analysis for Cuba has shown no significant change in preference degree of its traditional sugar importers (former-Soviet Union, China and Japan) although the total amount exported has decreased. Competitiveness and importers' market composition growth components have negatively affected Cuban exports evolution. However, results do not suggest that Brazil has replaced the loss in Cuba's share in the sugar world trade flow, at least on these main Cuban's importing markets.

Substitution elasticities were estimated through simple regressions employing ordinary least squares. Negative values statistically significant were found for: Brazil/South Africa (total sugar; raw sugar); Brazil/France (raw); Brazil/Philippines (refined) and Brazil/Germany (refined). This result indicates the substitutability between sugar exported by both countries, and therefore, the competition between them for the world market. Elasticities below one were observed for Brazil/Philippines (total sugar) and Brazil/Australia (refined), revealing a low degree of substitution between goods of the two sources and so product differentiation by their importers. 


\section{INTRODUÇÃO}

\subsection{O problema e sua justificativa}

O mercado brasileiro de açúcar tem se caracterizado, recentemente, por transformações importantes, que sugerem a necessidade de um redirecionamento das políticas setoriais e comerciais, relacionadas com a produção e comercialização não somente desse produto, mas também da cana-de-açúcar e do álcool. O desenvolvimento tecnológico e as medidas que vêm sendo adotadas para a desregulamentação são dois fatores que podem contribuir para essas transformações.

No mercado doméstico, tem havido maior participação da sociedade na discussão de assuntos relacionados ao setor sucroalcooleiro, destacando-se o redirecionamento do Proálcool; o enfraquecimento do sistema de cotas para a cana e seus produtos, do controle dos preços e das exportações; a estacionalidade do emprego e os movimentos migratórios interregionais temporários relacionados às atividades na lavoura e indústria da cana; o desenvolvimento e o aproveitamento de seus subprodutos; as queimadas e a mecanização na colheita, entre outros.

No âmbito internacional, as metas globais de liberalização propostas pelo Acordo Geral de Comércio e de Tarifas - GATT atingiram pouco o funcionamento do mercado de açúcar. Isso ocorre apesar do produto ser uma das commodities mais sujeitas a medidas protecionistas nas transações internacionais, além de se caracterizar pela intensa regulamentação estatal nos mercados domésticos, tanto em paises produtores como também em consumidores.

Relacionado ainda a esse mercado, o Conselho de Política Internacional sobre Agricultura, Alimentação e Comércio (IPC) levantou a necessidade de reformas nas politicas de açúcar, ressaltando a eliminação de subsídios às exportações, redução das 
tarifas de importação e do regime de quotas de importação nos arranjos preferenciais. Em relatório recente, o IPC confirma que as políticas para os produtos lácteos e para o açúcar foram pouco alteradas pela Rodada Uruguai do GATT, e dai a necessidade de serem retomadas pela Organização Mundial de Comércio, ainda no final de 1996 (Gazeta Mercantil, 1996). Nos últimos quinze anos, os preços dos cereais no mercado mundial declinaram aproximadamente $50 \%$, enquanto os do açúcar subiram $11 \%$.

No contexto global, uma tendência que pode afetar a dinâmica do mercado de açúcar é a formação de blocos econômicos. No que se refere a esse processo, de maneira geral, Nonnenberg $(1994$, p.2) estabelece que:

“A definição de estratégias globais de inserção da economia nacional no plano mundial deve estar atrelada às estratégias relativas a mercados e produtos especificos. A politica comercial, sobretudo nos seus aspectos relacionados ao processo de integração continental, necessita de informações em nível mais desagregado, analisando-se o crescimento das exportações dos principais produtos para os principais mercados de destino."

Novos cenários de atuação exigem que as políticas sejam compativeis com os objetivos reformulados. Assim, diante da recente formação de um mercado comum entre a Argentina, Brasil, Paraguai e Uruguai, que constituem o MERCOSUL, da tendência de liberalização comercial e da gradual desregulamentação do setor sucroalcooleiro no mercado doméstico, torna-se importante avaliar a melhor forma de explorar o potencial brasileiro para produzir e exportar açúcar. Para tanto, é necessário conhecer as possibilidades existentes no mercado internacional, a fim de subsidiar a adoção de estratégias comerciais que possam favorecer a competitividade dessas exportações e a manutenção ou acréscimo da participação no mercado ("market-share").

As estatísticas sobre o potencial de produção brasileira de açúcar e do total comercializado no mercado mundial justificam a relevância dessa proposta. $\mathrm{O}$ mercado internacional de açúcar, incluindo as cotas preferenciais, está estimado em 28 milhões de toneladas (Gazeta Mercantil, 1995). No Brasil, utilizando alguns coeficientes 
de transformação ${ }^{1}$ e os dados da Tabela 1 , estima-se que os 14,03 milhões de $\mathrm{m}^{3}$ de álcool a serem produzidos absorvem aproximadamente 193 milhões de toneladas de cana, que se fossem utilizadas para a produção de açúcar, corresponderiam a aproximadamente 19,30 milhões de toneladas adicionais no total produzido pelo País desse produto. Observa-se, ainda, que do volume total da produção de açúcar, 13,78 milhões de toneladas, $41 \%$ destinaram-se à exportação, sendo que o restante foi absorvido no mercado doméstico.

Tabela 1- Produção no setor sucroalcooleiro brasileiro para o ano safra 1996/97

\begin{tabular}{ccccccc}
\hline & \multicolumn{3}{c}{ Álcool (milhões $\mathrm{de}^{3}$ ) } & \multicolumn{3}{c}{ Açúcar (milhões de toneladas) } \\
REGIÃO & Anidro & Hidratado & Total & $\begin{array}{c}\text { Mercado } \\
\text { Interno }\end{array}$ & Exportação* & Total \\
\hline Centro-Sul & 3,85 & 8,28 & 12,13 & 6,48 & 3,67 & 10,48 \\
N-NE & 0,80 & 1,10 & 1,90 & 1,65 & 1,53 & 3,30 \\
Total Brasil & 4,65 & 9,38 & 14,03 & 8,13 & 5,2 & 13,78 \\
\hline
\end{tabular}

Fonte: AIAA, comunicação pessoal, abr.1997.

* Conforme o Plano de Safra 1996/97. citado por DataNet - Agricommodities, maio 1996.

A disponibilidade de matéria-prima aliada à estrutura básica do parque industrial sucroalcooleiro, permitem uma certa flexibilidade nas quantidades produzidas de açúcar e de álcool. Assim, a produção e a disponibilidade de açúcar dependem, estruturalmente, da política energética e de combustíveis. Nastari (1994) destaca a importância dessa flexibilidade existente no Brasil, de forma que a cana-de-açúcar originalmente destinada à produção de álcool pode ser transformada em açúcar quando necessário.

Segundo dados apresentados na DATAGRO e indicados por Nastari (1994), na safra $1991 / 92$ cerca de $72 \%$ da cana moída no País foi destinada à produção de álcool. De acordo com os cálculos para a safra 1996/97, utilizando os coeficientes

${ }^{1}$ Considera-se que cada tonelada de cana gera $100 \mathrm{~kg}$ de açúcar ou, alternativamente, 72.5 litros de álcool. Ver Stalder \& Burnquist (1995). 
técnicos de produção (Stalder \& Burnquist, 1995) e os números da Tabela 1, verifica-se que ao redor de $58 \%$ da cana produzida no Brasil destinou-se à produção de álcool ${ }^{2}$ e os $42 \%$ restantes à produção de açúcar.

A segunda implicação é decorrente da primeira, sendo relacionada à possibilidade do Brasil transformar uma parcela maior da cana produzida em açúcar, o que indica que o País tem potencial para elevar sua oferta para exportação e, consequentemente, causar impacto no mercado internacional. Desde que o potencial produtivo de açúcar do País praticamente corresponde ao volume transacionado no mercado mundial, pode-se inferir que o Brasil tem possibilidades de exercer um papel significativo na evolução deste mercado .

Os estudos de competitividade internacional têm, em geral, considerado apenas o fator preço como determinante das relações de troca, muitas vezes, por simplificação. No entanto, outras variáveis além do preço têm contribuído na definição da oferta e demanda mundiais, sendo que algumas dessas foram incorporadas à análise, já que adequadas ao contexto analítico definido. Dentre esses, destacam-se: a qualidade e diferenciação de produtos, tendências da economia e política mundiais, modificações nos padrões de consumo, desenvolvimento de produtos substitutos e fatores institucionais.

Embora não sejam adequadas ao contexto analítico utilizado no presente estudo, é importante ressaltar que variáveis macroeconômicas, tais como a taxa de câmbio e de juros, tiveram um papel fundamental na definição das relações comerciais brasileiras; e, muito provavelmente, na forma de evolução das exportações de açúcar. A taxa de câmbio, por exemplo, particularmente durante a década de 90 , vem sendo apontada como um fator que tem influenciado negativamente as exportações. Várias análises têm indicado que essa taxa tem-se mantido valorizada em função dos planos de estabilização econômica implementados na economia brasileira, o que tende a prejudicar as exportações.

No presente estudo, o objetivo básico é analisar as interrelações do Brasil com os mercados importadores e demais países exportadores no decorrer das décadas de 80 e 90 .

\footnotetext{
${ }^{2}$ Na safra 1991/92, 72\% da cana moida no Brasil foi destinada à produção de álcool (DATAGRO, citado por Nastari, 1994).
} 
Para tanto, é necessário examinar os fatores que definiram o padrão e a participação brasileira nas exportações mundiais de açúcar. Além disso, procurar-se-á avaliar a forma pela qual o País pode influenciar e ser influenciado pelas alterações na oferta e demanda globais, e pelas mudanças nas políticas de condução interna do setor.

Ressalta-se que o interesse em estudar o padrão das relações comerciais do Brasil para o açúcar e o perfil desse mercado internacional justifica-se não só devido aos novos delineamentos políticos do setor, mas também pela pouca disponibilidade de trabalhos recentes sobre esse assunto. Sugere-se que essa carência esteja relacionada à intervenção do Estado no funcionamento desse mercado, cuja rigidez e protecionismo na formulação de suas políticas tornavam secundárias as questões sobre competitividade e desempenho do setor sucroalcooleiro em situações de mercado desregulamentado.

\subsection{Objetivos}

O objetivo principal deste trabalho é avaliar os fatores determinantes da participação do Brasil como exportador de açúcar no mercado mundial, e, consequentemente, fornecer subsídios para a formulação de políticas setoriais $\mathrm{e}$ comerciais que favoreçam o seu desempenho, sob o escopo das novas tendências do mercado doméstico e externo. Para proceder a esta avaliação o trabalho procura atingir as seguintes metas:

- Apresentação de análise descritiva da evolução do padrão de comércio de açúcar do Brasil quanto aos seus principais importadores, ao longo do período 1979 a 1994;

- Analisar a participação brasileira ("market-share") no mercado de açúcar, avaliando de forma "ad hoc" quais fatores, além dos preços, determinam essa participação e são responsáveis pelas variações nos fluxos de comércio ocorridas no periodo estudado;

- Obter estimativas de elasticidade de substituição para o açúcar brasileiro, avaliando o grau de competitividade existente entre os principais países exportadores; 


\section{REVISÃO DE LITERATURA}

\subsection{Caracterização do setor sucroalcooleiro no Brasil}

A importância da cana-de-açúcar no Brasil remonta ao período colonial, estando consolidada até os dias de hoje por constituir matéria-prima básica para a extração não só do açúcar mas também do álcool, e por gerar vários subprodutos dos quais diversos apresentam elevado potencial energético.

A cana-de-açúcar e seus produtos tem sua importância também relacionada à geração de empregos e de divisas. Segundo Szmrecsányi (1979), no ano de 1974, devido a um grande aumento dos preços internacionais, o açúcar foi o primeiro produto na pauta das exportações, sendo que a agroindústria canavieira chegou a representar 5\% do PIB total, valor que normalmente era de $3 \%$. Algumas estatisticas que indicam a dimensão do setor sucroalcooleiro na economia brasileira, divulgadas no início de 1996, são: o faturamento agregado do setor estimado em 8,6 bilhões de dólares dos quais 7,1 bilhões provenientes da região Centro-Sul; e o parque industrial instalado, compreendendo 346 indústrias, sendo 143 destilarias autônomas (produção apenas de álcool) e 203 usinas de açúcar e álcool (DataNet - Agricommodities, maio/1996).

Trata-se de uma cultura presente em quase todo o território nacional, ocupando cerca de 4,5 milhões de hectares e que se expandiu bastante nas décadas $70 \mathrm{e}$ 80 não só em área cultivada, mas também pela intensa assimilação de tecnologia. Segundo Burnquist \& Bacchi (1996b), a área cultivada com cana permaneceu praticamente estável na década 60 até meados da década seguinte, quando passou a crescer a taxas bastante elevadas. No período de 1977 a 1984 apresentou expansão da ordem de $7,84 \%$ ao ano, em termos per capita, tendo sido considerado o melhor 
desempenho dentre algumas culturas domésticas, administradas e de exportação, avaliadas por Homem de Melo (1986).

Para o periodo compreendido entre 1985 e 1995, a taxa geométrica de crescimento da área cultivada de cana para o Brasil foi estimada em $0,56 \%$, com aumentos maiores para as regiões Sul e Centro-Oeste, destacando-se os estados do Paraná e Mato Grosso, sendo que a região Norte-Nordeste apresentou taxas negativas. Atualmente, a cana-de-açúcar tem permanecido entre as cinco maiores culturas do Brasil, tanto em termos de área quanto em valor da produção (Burnquist \& Bacchi, 1996b).

Apesar dessa a taxa de crescimento discreta nos últimos anos, o setor vem apresentando uma série de transformações evidenciando que os incrementos na produção não se devem somente à evolução da área plantada. Tais transformações envolvem tanto o aumento de produtividade e da produção dos produtos básicos dessa indústria, açúcar e álcool, quanto a diversificação no aproveitamento de subprodutos e resíduos. Entre esses destacam-se aqueles usados como adubo nas próprias usinas, a vinhaça e a torta de filtro, e como fonte de energia, o bagaço, a vinhaça e as pontas da cana (Stalder \& Burnquist, no prelo).

Investimentos em biotecnologia e novas variedades resistentes a doenças deverão garantir ganhos de produtividade, sendo que, concomitantemente, obtém-se a redução dos custos industriais e agricolas, com bons prognósticos ainda nesse último item, o que contribui para elevar a competitividade da indústria no mercado internacional. Segundo Eid (1996), a partir da segunda metade da década de 80, os grupos envolvidos na atividade sucroalcooleira vêm difundindo essas novas tecnologias disponíveis na agroindústria integrando-a aos novos delineamentos na gestão da mão-de-obra. Esse autor relaciona essas mudanças como resposta às transformações nos mercados mundiais.

A importância econômica e social da cana estende-se por todo o País. É comum dividir-se o Brasil em duas grandes regiões produtoras sucroalcooleiras, a Centro-Sul e a Norte-Nordeste. O custo de produção é geralmente lembrado como um dos fatores que distinguem essas duas regiões. Esses custos são mais elevados para a região Norte-Nordeste, US\$ 300 por tonelada, comparados a US\$220/t na região Centro-Sul (Eid, 1996), caracterizando-se ainda por um cultivo menos tecnificado e 
niveis de eficiência inferiores aos apresentados na região Sul-Sudeste (há exceções à regra em ambas regiões). Na safra 1995/96, a região Centro-Sul e o Estado São Paulo responderam, respectivamente, por $81 \%$ e $60,8 \%$ da produção nacional de cana (Burnquist \& Bacchi, 1996b).

A intensidade do uso da mão-de-obra e da mecanização nas diversas etapas da produção diferem nas duas regiões. Pode-se dizer ainda, que se diferenciam pela própria evolução histórica da cultura e por apresentarem épocas de colheita e de produção distintas (a região Norte-Nordeste começa a produzir açúcar mais tardiamente). Além disso, a prioridade na produção açucareira nordestina tem sido atender à demanda do tipo demerara, tradicionalmente exportado. Historicamente, essa região tem sido a grande responsável pelas exportações brasileiras, situação essa que se vem modificando nas últimas safras. A Tabela 2 apresenta as quantidades de cana-deaçúcar moída, açúcar e álcool total (hidratado e anidro) produzidos, ao longo do periodo de 1985 a 1996, desagregadas por regiões.

No periodo analisado, observa-se que a quantidade total de cana moída não se alterou muito. No entanto, houve uma discreta substituição de produção da região N/NE pela produção no Centro-Sul. A produção de álcool comportou-se da mesma forma. Já a quantidade de açúcar cresceu em função, basicamente, da contribuição da região Centro-Sul.

O Brasil também se destaca como um dos maiores consumidores mundiais de açúcar. A demanda por açúcar no mercado brasileiro caracteriza-se por um consumo per capita anual de aproximadamente $48,3 \mathrm{~kg}$, tendo-se calculado o consumo doméstico total em 8 milhões de toneladas para 1995 (Burnquist \& Bacchi, 1996a). Segundo as autoras, estima-se que aproximadamente $60 \%$ do açúcar absorvido pelo mercado doméstico destina-se ao consumo direto. $\mathrm{O}$ restante é direcionado ao consumo indireto, como matéria-prima nas indústrias de refrigerantes, bebidas, balas, chocolates, bolachas etc. Dessa forma, sendo a participação das indústrias na demanda doméstica por açúcar bastante acentuada, o desempenho industrial tornou-se um importante indicador do nível de consumo do produto. 
Tabela 2 - Quantidade de cana-de-açúcar moída, produção de açúcar total (em equivalente demerara) e de álcool (anidro e hidratado), na região NorteNordeste, Centro-Sul e no Brasil. Safras 1985/86 a 1996/97

\begin{tabular}{lllllllllll}
\hline SAFRA & \multicolumn{2}{c}{ CANA MOÍDA $(1000 \mathrm{t})$} & \multicolumn{2}{c}{ AÇUCAR $(1000$ Sacas 50kg) } & \multicolumn{3}{c}{ ÁLCOOL ANIDRO E HIDR. $\left(\mathrm{m}^{3}\right)$} \\
& N/NE & C-SUL & BRASIL & N/NE & C/SUL & BRASL & N/NE & C/SUL & BRASL \\
\hline $85 / 86$ & 61.068 & 162.604 & 223.672 & 63.768 & 92.405 & 156.173 & 2.021 .100 & 9.746 .278 & 11.767 .378 \\
$86 / 87$ & 71.267 & 152.979 & 224.246 & 66.970 & 96.292 & 163.262 & 2.214 .969 & 8.296 .009 & 10.510 .978 \\
$87 / 88$ & 54.483 & 168.815 & 223.298 & 63.167 & 94.061 & 157.228 & 1.790 .598 & 9.662 .733 & 11.453 .331 \\
$88 / 89$ & 52.145 & 166.200 & 218.345 & 56.339 & 105.065 & 161.404 & 1.753 .625 & 9.963 .530 & 11.717 .155 \\
$89 / 90$ & 60.469 & 163.354 & 223.823 & 62.613 & 82.795 & 145.408 & 2.017 .996 & 9.900 .892 & 11.918 .888 \\
$90 / 91$ & 53.300 & 170.000 & 223.300 & 57.130 & 90.177 & 147.307 & 1.806 .342 & 9.975 .462 & 11.781 .804 \\
$91 / 92$ & 49.400 & 178.992 & 228.392 & 55.393 & 116.694 & 172.087 & 1.749 .009 & 10.967 .301 & 12.716 .310 \\
$92 / 93$ & 47.417 & 176.296 & 223.713 & 62.601 & 122.371 & 184.972 & 1.630 .565 & 10.057 .734 & $11.688,299$ \\
$93 / 94$ & 38.010 & 184.088 & 222.098 & 46.524 & 140.140 & 186.664 & 910.751 & 10.381 .434 & 11.292 .185 \\
$94 / 95$ & 44.630 & 196.310 & 240.940 & 64.230 & 168.940 & 233.170 & 1.550 .000 & 11.150 .000 & 12.700 .000 \\
$95 / 96^{*}$ & 45.596 & 204.404 & 250.000 & 66.751 & 186.306 & 253.058 & 1.734 .219 & 10.849 .173 & 12.583 .392 \\
$96 / 97^{*}$ & $51.150^{* *}$ & $225.000^{* *} 276.150^{* *}$ & 66.000 & 209.568 & 275.568 & 1.900 .000 & 12.130 .629 & 14.030 .629 \\
\hline
\end{tabular}

Fonte: Dados da COPERSUCAR (1995) ${ }^{3}$.

*AIAA, comunicação pessoal, abril 1997.

** Plano de Safra 1996/97.

$\mathrm{Na}$ caracterização do setor sucroalcooleiro no Brasil é importante enfatizar o papel da intervenção governamental, presente desde a produção da matériaprima até a exportação e importação de seus produtos. Essa intervenção direta ficou evidente após a criação do Instituto do Açúcar e do Álcool (IAA), em 1933, tornando-se mais intensa a partir de 1975, após a implantação do Programa Nacional do Álcool (Proálcool). Os principais instrumentos de controle eram instituídos através dos Planos de Safra, determinando e distribuindo cotas de produção de açúcar e de álcool, cotas de

${ }^{3}$ COOPERATIVA DOS PRODUTORES DE ACCÚCAR E ÁLCOOL DO ESTADO DE SÃO PAULO (COPERSUCAR), São Paulo. Comunicação pessoal, 1995. 
exportação de açúcar, restrições às importações de álcool, além da fixação de preços para cana, açúcar e álcool.

A regulamentação atingiu de forma marcante o setor brasileiro de exportação de açúcar. A participação do País no mercado mundial do açúcar intensificouse na década de 60 , sendo que o IAA estabelecia, para cada safra, o volume de açúcar a ser produzido e exportado, baseando-se nas condições do mercado mundial, nos compromissos de participação nos Acordos Internacionais de Açúcar, e na disponibilidade de cana (Szmrecsányi, 1979).

Entretanto, fatores como a crise do petróleo em 1973, a necessidade de reduzir o déficit da balança comercial brasileira e a criação do Proálcool tornaram prioritária a obtenção do álcool em detrimento ao açúcar. Dessa forma, a atuação do governo foi no sentido de garantir o abastecimento doméstico de álcool carburante para a frota crescente de veículos ${ }^{4}$.

Assim, desde a criação do Proálcool até o final da década de 80 , pode-se dizer que as exportações de açúcar e as políticas para assegurar novos mercados consumidores foram colocadas em segundo plano. Segundo Burnquist \& Bacchi (1994), o principal ponto de estrangulamento na geração de excedentes exportáveis de açúcar pelo setor era a necessidade de atender à demanda interna de álcool. Este panorama temse modificado desde 1990, após a extinção do IAA, o que levou à desestruturação do sistema de fiscalização, facilitando a abertura para as exportações.

De maneira geral as transformações do setor, mencionadas no início deste capítulo, envolvem também a tendência de redução na tutela estatal sobre a agroindústria sucroalcooleira brasileira, gerando perspectivas favoráveis para o açúcar de exportação. Por outro lado, o setor tem-se defrontado com a redução drástica do crédito rural, as elevadas taxas de juros e, ainda, segundo alguns de seus representantes, a defasagem dos preços da cana e dos seus produtos. Tais fatores têm contribuído também para promover modificações estruturais na produção e comercialização de açúcar e álcool.

\footnotetext{
${ }^{4}$ Segundo Pereira Filho (1995), a venda de carros a álcool chegou a representar $96 \%$ do total de veículos leves vendidos em 1985, chegando a $3,6 \%$ em 1995. Atualmente, representa menos de $1 \%$ dos automóveis vendidos. Apesar disto, o álcool hidratado ainda atende a mais de 4,5 milhões de unidades.
} 
Dentre as medidas que afetam diretamente o desempenho do setor exportador de açúcar, destaca-se o menor rigor na determinação das cotas e de sua distribuição. Segundo Bastos Filho (1995), no Plano de Safra 95/96 ficou estabelecido um limite de exportações isentas do imposto de exportação, sendo que a distribuição dessas cotas entre as usinas passou a ser menos rígida. Esse imposto de exportação varia de $3 \%$ a $40 \%$ ad valorem, para as quantidades que ultrapassarem as cotas autorizadas.

No Brasil, as reformas que compreendem a redução do "custo Brasil", impostos e taxações nos portos, além da definição de política de câmbio e juros internos, devem balizar o ganho em competitividade nas exportações de açúcar (Camargo Neto, 1996). A recente aprovação, em setembro de 1996, da isenção do Imposto sobre Circulação de Mercadorias e Serviços - ICMS, para produtos brutos e semi-elaborados de exportação, é uma contribuição nesse sentido, desonerando as exportações de açúcar demerara em $12,2 \%$, segundo as informações divulgadas na revista Suma Agrícola \& Pecuária de outubro desse mesmo ano.

Nos últimos anos, devido a essa desregulamentação parcial, viabilizaramse operações denominadas "swaps", que consistem na exportação de quantidades de açúcar superiores às cotas pré-determinadas, e na importação simultânea de etanol e metanol visando suprir as suas cotas internas de álcool. A operação resultou, na média, em um ganho de US\$50 por tonelada em equivalente de açúcar (Agroanalysis, 1995). O uso da mistura metanol-etanol-gasolina (MEG) também consistiu num dos fatores que permitiram que um maior volume de açúcar fosse exportado nos últimos anos, uma vez que a necessidade de produção de etanol se reduziu.

É importante mencionar, retomando a importância das variáveis macroeconômicas, que a taxa de juros também esteve relacionada à evolução favorável das exportações de açúcar, à medida que os exportadores do produto puderam se beneficiar, neste início da década de 90 , da possibilidade de pré-pagamento e financiamento relacionados aos Adiantamentos de Contratos de Câmbio (ACC's). Os ACC's vêm desempenhando uma função de "instrumento financiador" da produção doméstica, uma vez que permite ao produtor aproveitar as taxas de juros internacionais mais baixas em relação aos niveis contabilizados no Brasil. Segundo Burnquist \& Bacchi 
(1996b), esse mecanismo pode ser interpretado como uma forma de "importar" taxas de juros mais baixas em troca de exportações de açúcar. Em contrapartida, a produção de álcool foi prejudicada pelas elevadas taxas de juros domésticas, que oneram pesadamente o carregamento de seus estoques ao longo do ano.

As quantidades totais exportadas de açúcar podem ser observadas na Tabela 3. A região Centro-Sul passou a ser o maior pólo exportador de açúcar do País a partir da safra 1993/94, o que foi possível dada a nova forma de gerenciar a distribuição das cotas.

Tabela 3 - Exportações brasileiras de açúcar total (em equivalente demerara) por região de origem - 1985/86 a 1996/97

\begin{tabular}{cccc}
\hline SAFRA & CENTRO-SUL & NORTE-NORDESTE & BRASIL \\
\cline { 2 - 4 } & & ( TONELADAS) & \\
\hline $85 / 86$ & 89.390 & 1.834 .469 & 1.923 .859 \\
$86 / 87$ & 17.861 & 1.560 .772 & 1.578 .633 \\
$87 / 88$ & 10.878 & 1.688 .315 & 1.699 .193 \\
$88 / 89$ & 98.172 & 1.366 .177 & 1.464 .289 \\
$89 / 90$ & - & 1.104 .752 & 1.104 .752 \\
$90 / 91$ & 83.859 & 1.145 .825 & 1.229 .684 \\
$91 / 92$ & 414.456 & 1.290 .000 & 1.704 .456 \\
$92 / 93$ & 882.199 & 1.200 .000 & 2.082 .199 \\
$93 / 94$ & 1.666 .826 & 775.104 & 2.441 .930 \\
$94 / 95$ & 2.683 .439 & 1.656 .779 & 4.340 .217 \\
$95 / 96$ & 3.489 .096 & 1.613 .179 & 5.102 .275 \\
$96 / 97 *$ & 3.670 .000 & 1.530 .000 & 5.200 .000 \\
\hline
\end{tabular}

Fonte: IAA, CACEX, DTIC e AIAA, citado por Agroanalysis (1995) e AIAA, comunicação pessoal, abril 1997.

* 1996/97 (DataNet - Agricommodities, maio/1996). 
No entanto, alguns privilégios permanecem. Por exemplo, a continuidade do monopólio de exportação de açúcar para o mercado norte-americano (cotas preferenciais) pelas usinas nordestinas. Segundo Burnquist (1996) tem ocorrido um avanço na participação de estados não tradicionais também nas exportações de açúcar, destacando-se Paraná, Goiás e Minas Gerais, em periodo recente.

As importações brasileiras de açúcar tem sido marginais, consistindo basicamente do tipo demerara, que é usado para reprocessamento e transformação em refinado. O Brasil consta como um dos países que realizam operações denominadas "tolling" ou "draw-back", que consistem em importar açúcar demerara para ser refinado e, em seguida, exportado, utilizando assim a capacidade ociosa da indústria, principalmente em periodos de entressafra. Outros países destacam-se nessa operação, tais como China, Cingapura, Rússia, EUA e Venezuela. O "tolling" depende fundamentalmente do mercado de prêmios, ou seja, do diferencial de preços entre o mercado de açúcar demerara e o mercado de refinado (Seminário GEPLACEA, 1992).

\subsection{Panorama do mercado exportador brasileiro de açúcar}

A comercialização do açúcar brasileiro vem passando por um período de transição que tem resultado no aumento das exportações, sendo que a expectativa futura é de supressão total das cotas de exportação. Nesse contexto, torna-se questionável se as alterações têm sido geradas por mudanças na estrutura do mercado mundial de açúcar, na estrutura doméstica de produção e comercialização, ou em ambas.

O período utilizado para proceder à análise descritiva da evolução das exportações brasileiras e de sua representatividade no total mundial comercializado compreende o período de 1979 a 1994, subdividido em três subperíodos, a saber: 1979/84, 1985/89 e 1990/94. Esse padrão foi também adotado para proceder à análise de "market-share" descrita no capítulo de metodologia. O critério para essa escolha baseou-se na observação da tendência das quantidades exportadas ao longo desse periodo, conforme apresentado na Figura 1. Verifica-se um aumento no volume exportado no primeiro subperíodo, sendo que a partir de 1985 até 1989 observou-se uma tendência decrescente, revertida a partir de 1990. 


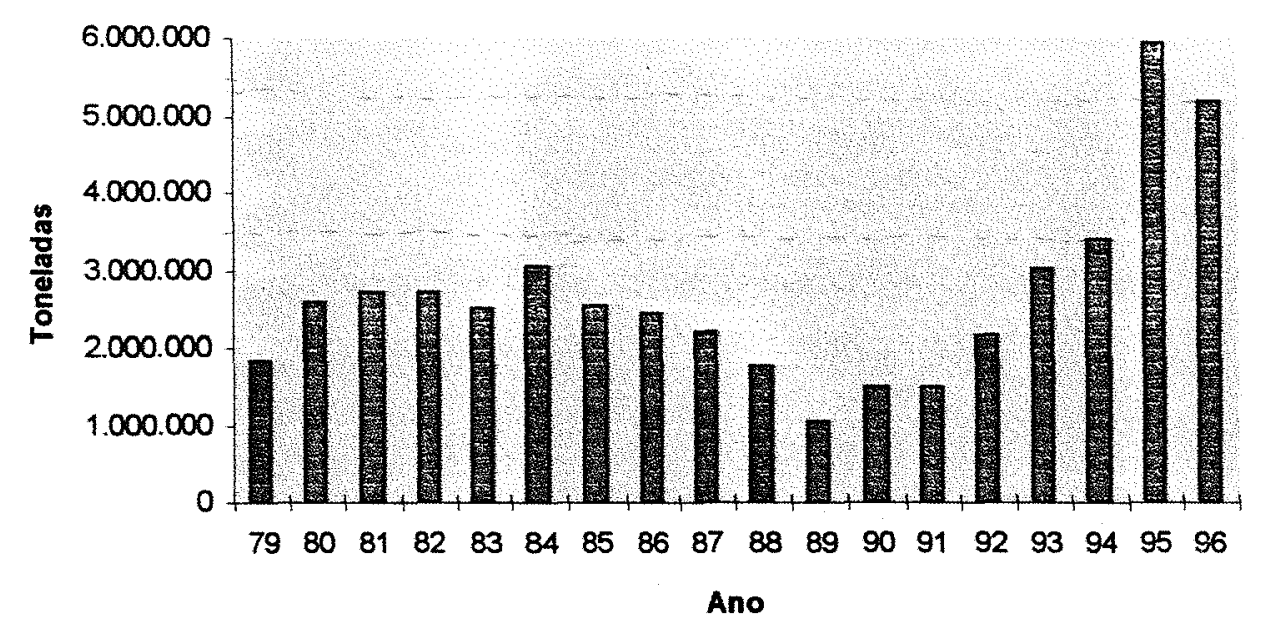

Figura 1 - Exportações brasileiras de açúcar, em toneladas, no periodo de 1979 a 1996. Fonte: Carteira de Comércio (CACEX), SECEX, e Plano de Safra 1996/97.

Apesar dos anos 1995 e 1996 não constarem do período proposto neste trabalho, verifica-se na Figura 1 que as exportações brasileiras de açúcar, em tendência ascendente desde 1990, cresceram consideravelmente em 1995, apresentando um aumento de $52,94 \%$ em relação ao ano anterior, possivelmente estimuladas pelos fatores discutidos a seguir.

A evolução do comércio de açúcar brasileiro com o exterior, após 1990, permite supor que as medidas políticas de desregulamentação sobre o setor sucroalcooleiro, aliadas à indefinição das novas diretrizes para o programa do álcool, possibilitaram maior flexibilidade na comercialização e produção do açúcar e do álcool, e, portanto, melhores oportunidades de participar no mercado externo.

Recentemente, além do acesso mais fácil do produtor e exportador brasileiro ao mercado externo, outros fatores que contribuíram para incentivar o crescimento das exportações açucareiras do Brasil e o aumento da demanda por esse produto constituíram-se em: existência de diferenciais de preços internos e externos favoráveis ao segundo em 1994 e 1995; e quebra da safra de grandes produtores como a Índia, China e Cuba. 
Cálculos realizados a partir de dados da Secretaria de Comércio Exterior ${ }^{5}$ (SECEX) mostram que os países da Ásia e da África juntos, responderam por 80 e 66\% das exportações brasileiras de açúcar nos anos de 1994 e 1995, respectivamente. Em 1994, a Índia foi o maior importador de açúcar do Brasil devido à quebra de sua safra, tendo absorvido $43,62 \%$ de todo o produto exportado pelo Brasil. Em 1995, destacaramse os paises que compõem a ex-URSS (especialmente a Federação Russa) absorvendo $19 \%$ do total exportado pelo Brasil.

O MERCOSUL absorveu apenas $6,55 \%$ e 3,15\% das exportações brasileiras de açúcar nos anos de 1994 e 1995, respectivamente, participação ainda bastante modesta comparada a dos mercados asiáticos e africanos. As possibilidades de assimilação do açúcar excedente brasileiro pelos países da América do Sul deveriam ser analisadas não só considerando os atuais componentes do MERCOSUL, mas novas parcerias com países sul-americanos que tradicionalmente importam o produto, como a Venezuela, Chile, Bolívia e Peru.

A Figura 2 evidencia que, nos últimos dois anos analisados, 1993 e 1994, - Brasil conseguiu recuperar o nivel de participação que detinha no mercado mundial de exportação de açúcar em 1984, ultrapassando-o e chegando a mais de $12 \%$. Nesses últimos anos, o Brasil tem exportado entre 20 e $30 \%$ do açúcar produzido domesticamente, sendo que em 1995 chegou a 35\%.

No primeiro subperiodo da análise (1979/84) o País destinou, em média, $30 \%$ do total produzido de açúcar para o mercado externo, caindo para menos de $15 \%$ em 1989, tendo consequentemente apresentado a menor participação no mercado mundial exportador ao longo desses 16 anos $(3,65 \%)$. Nesse período, a necessidade de atender à demanda por álcool/combustível no mercado interno foi considerada fundamental para o estabelecimento das políticas governamentais para o setor.

${ }^{5}$ SECRETARIA DE COMÉRCIO EXTERIOR (SECEX), Rio de Janciro. Comunicação pessoal, 19891995. 


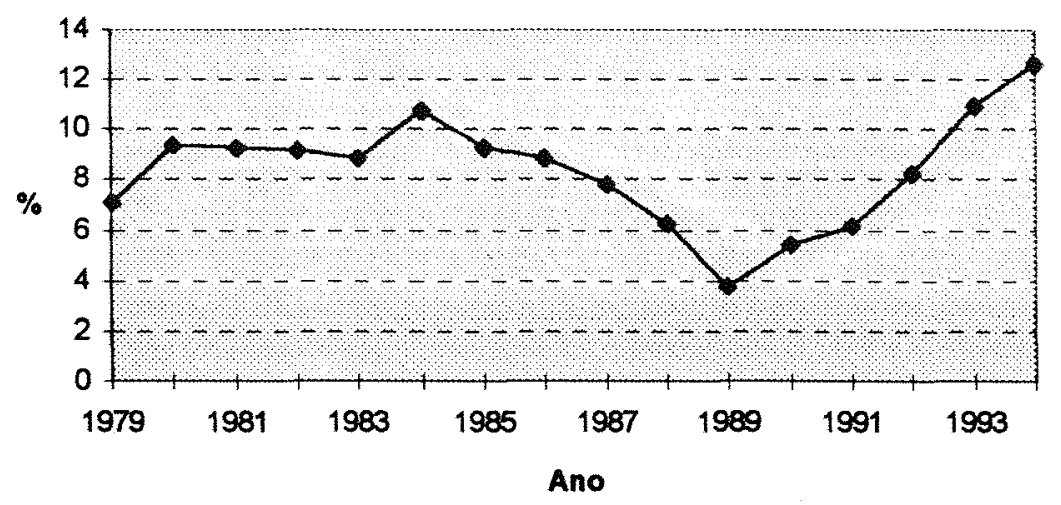

Figura 2 - Participação das exportações brasileiras de açúcar em relação ao total mundial comercializado. Fonte: Elaborado a partir de dados da FAO Trade Yearbook, 1979-1994.

É interessante observar que no ano de 1984 quando o Brasil teve a sua maior participação no mercado mundial de açúcar, os preços internacionais da commodity encontravam-se num patamar bastante baixo e o nível de estoques determinava uma elevada proporção estoque/consumo (Figura 3). Por outro lado, em 1989, quando o País reduziu drasticamente as exportações de açúcar, os preços internacionais atingiam a média máxima desde o ano 1980, com a relação de estoque/consumo praticamente estabilizada no nivel de $20 \%$.

No periodo entre 1978 a 1984, que praticamente compreende o primeiro subperíodo estudado, vigorou um Acordo Internacional de Açúcar, cujas prerrogativas eram justamente estabelecer faixas de preços para a distribuição de cotas e um mecanismo de estoques reguladores a serem financiados pelos próprios países membros. Os efeitos desse acordo para o Brasil são discutidos em Carvalho (1988), cuja conclusão final foi a de que teria havido efeito positivo do Acordo para o mercado exportador nacional.

Verifica-se na Figura 4 que a evolução da quantidade exportada pelo Brasil é muito semelhante à evolução da produção doméstica de açúcar, sugerindo que pode haver uma certa relação entre a disponibilidade interna do produto $\mathrm{e} o$ 
estabelecimento das cotas de exportação. Observa-se a redução tanto na produção quanto no volume de exportação de açúcar do produto no segundo subperíodo (1985/89). Como já foi mencionado anteriormente, a prioridade em atender o mercado interno de álcool combustível, e consequentemente uma política restritiva quanto às transações internacionais podem ter contribuído para essa fase descendente das exportações.

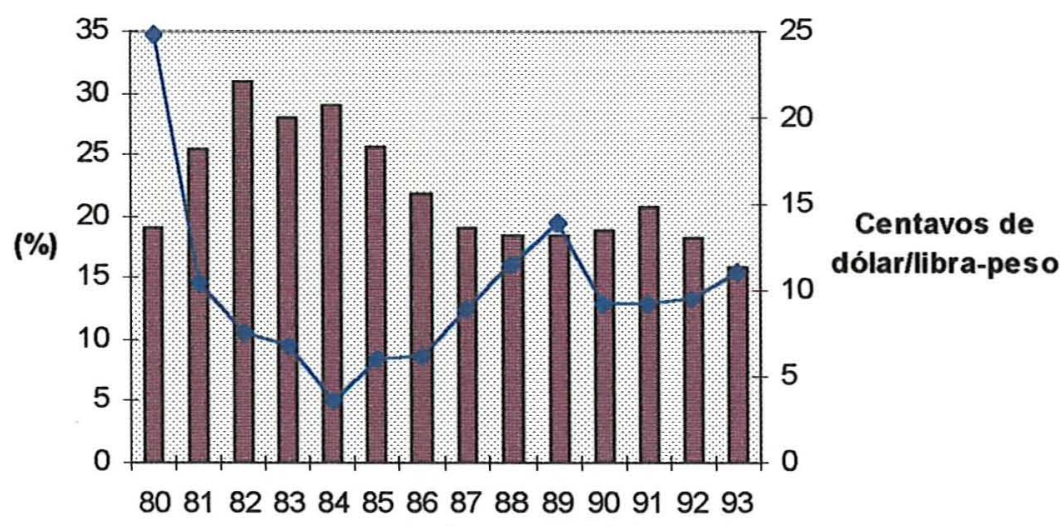

Ano

$\square$ Estoque/Consumo $\longrightarrow$ Preço

Figura 3 - Preço do açúcar demerara - contrato no 11 de Nova Iorque, FOB, em portos do Caribe, em centavos de dólar por libra-peso; relação estoque/consumo de açúcar. Fonte: Elaborado com dados da Sugar and Sweetener/USDA (1994).

O terceiro subperíodo, o mais relevante em termos de conclusões finais para este trabalho, inicia-se em 1990, ano marcado pela adoção de medidas heterodoxas pelo governo tendo em vista alcançar a estabilidade econômica. Tais medidas compreenderam, entre outras, o desencadeamento do processo de desregulamentação do sistema de cotas e de fixação de preços dos produtos para o setor sucroalcooleiro, extinguindo o órgão responsável pela administração dessas políticas, o Instituto de Açúcar e do Álcool (IAA), além de reduzir a liberação de crédito, principalmente o subsidiado. 


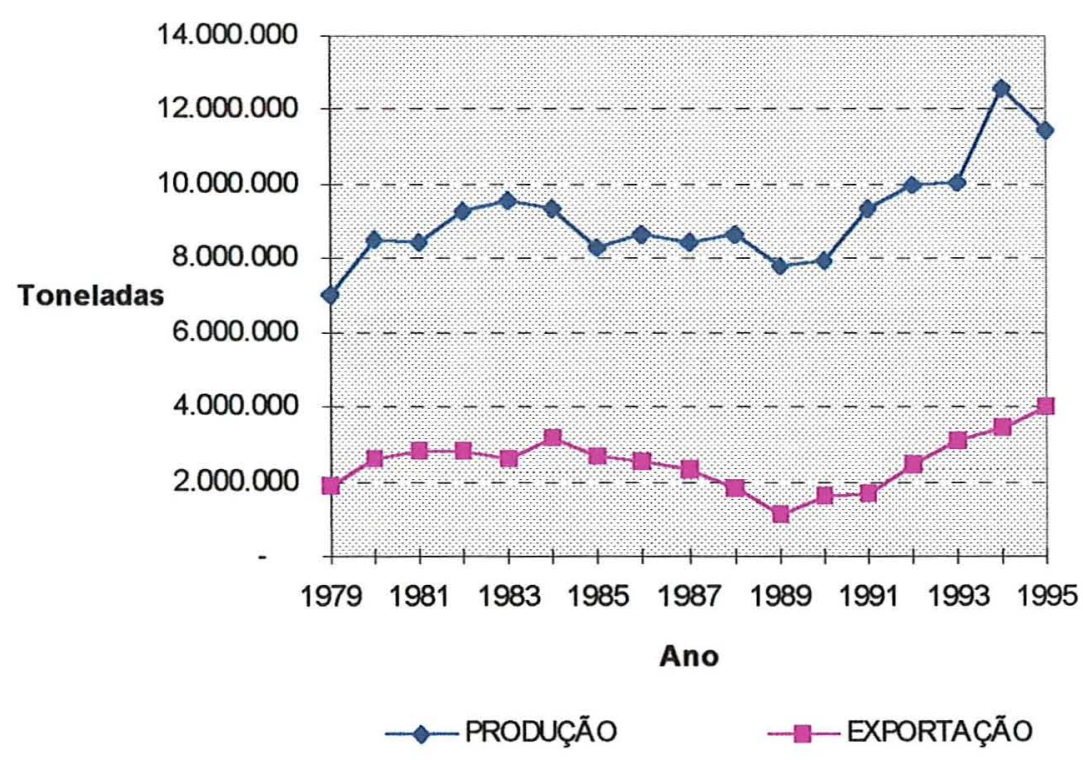

Figura 4 -Produção e exportação brasileira de açúcar, toneladas em equivalente demerara. 1979-1995. Fontes: Elaborado a partir de dados da FAO (SOFA 95) e Agroanalysis (1995).

As exportações de açúcar nesta fase não somente aumentaram em volume como se diferenciaram em termos de tipo de produto comercializado, mercados importadores e pela própria origem interna do açúcar, que passou a ser exportado em maior volume pela região Sul-Sudeste do que pela tradicional região exportadora nordestina. As taxas de crescimento das exportações de açúcar para os três tipos mais comumente comercializados: demerara, cristal e refinado, no período 1979-1996, foram estimadas por regressões simples, utilizando mínimos quadrados ordinários. Os resultados são apresentados na Tabela 4.

Tabela 4 - Taxas de crescimento das exportações do Brasil discriminadas por tipo de açúcar para o período 1979 a 1994

\begin{tabular}{|c|c|c|c|c|}
\hline \multirow[t]{2}{*}{ País } & \multicolumn{4}{|c|}{ Tipo de açúcar } \\
\hline & Total & Demerara & Cristal & Refinado \\
\hline Brasil & 3,82 & $-4,57$ & 11,52 & 0,08 \\
\hline
\end{tabular}

Fonte: Elaborado pelo autor segundo dados da CACEX, SECEX e Plano de Safra 1996.

Os resultados indicam o crescimento total das exportações de açúcar, observando-se que esse crescimento é decorrente principalmente do aumento nas 
quantidades exportadas de açúcar cristal, já que o crescimento do tipo refinado foi praticamente nulo e o do demerara, negativo. A evolução dessas exportações para cada tipo de açúcar pode ser melhor observada na Figura 5.

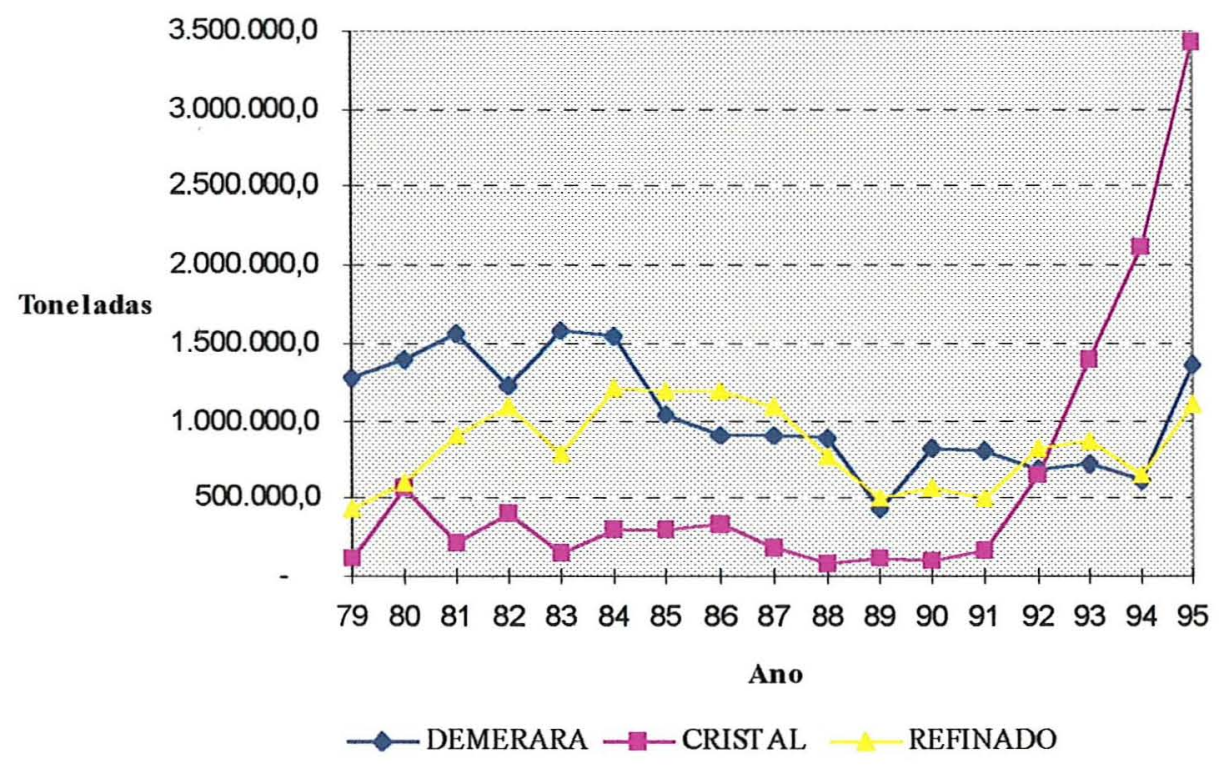

Figura 5 - Evolução das exportações brasileiras de açúcar cristal, demerara e refinado, em toneladas, para o período de 1979 a 1995. Fonte: Elaborado com dados da CACEX/SECEX.

Constata-se que houve uma modificação no tipo de demanda por açúcar brasileiro, aliada às mudanças já comentadas de caráter político-administrativo. Verificase pela figura que houve um aumento significativo nas quantidades exportadas de açúcar cristal, destacando-se à frente dos demais tipos, em termos de volumes, a partir de 1991. O tipo demerara passou por uma fase de redução nas quantidades exportadas, e, em seguida, voltou a um patamar correspondente ao que estava no início do período. A evolução para o açúcar refinado mostra que seu volume exportado aumentou com relação ao início do período, tendo apresentado comportamento variável ao longo desses 17 anos.

Uma análise mais detalhada dos fatores que determinam essas alterações na composição e volume da pauta de exportações do açúcar pode indicar que ocorreram não somente mudanças nas preferências dos importadores, mas também na participação 
dos mesmos como compradores do açúcar brasileiro, e nas próprias condições de oferta dos países no mercado mundial. A análise de "market-share" permite desagregar alguns desses fatores, principalmente aqueles referentes à identidade dos mercados importadores, suas preferências e participação no comércio mundial.

\subsection{O mercado internacional do açúcar}

A produção mundial de açúcar estimada para a safra 1996/97, pelo Departamento de Agricultura dos Estados Unidos - USDA, é de cerca de 120,2 milhões de toneladas, para um consumo total de valor um pouco inferior, 120 milhões de toneladas. A produção e o consumo mundiais de açúcar têm crescido praticamente às mesmas taxas no período analisado. As exportações do produto têm-se mantido num patamar estável enquanto os preços e estoques evoluíram em sentidos opostos em determinados anos (Figura 6).

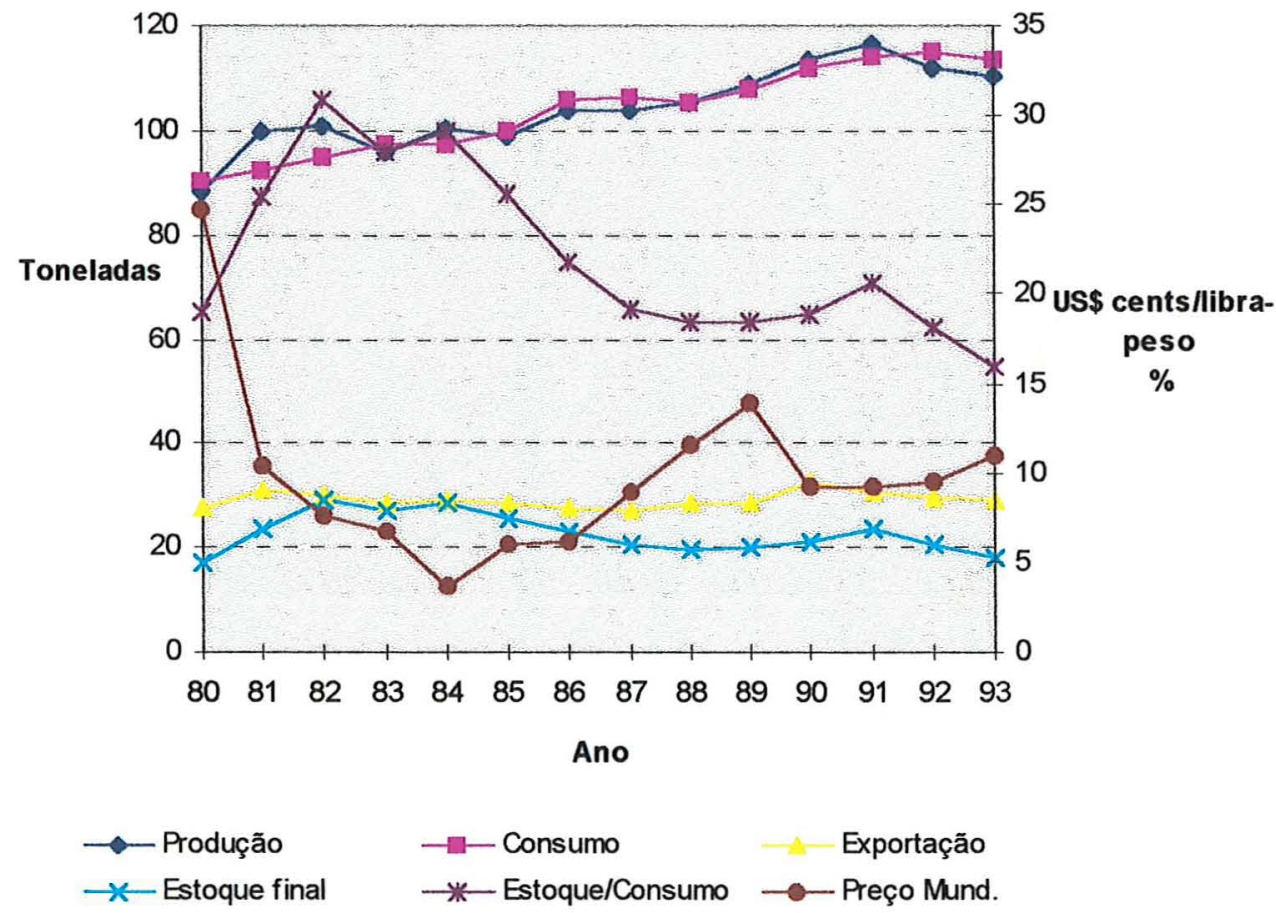

Figura 6 - Produção, consumo, exportação, estoque final (milhões de toneladas) e preço de açúcar no mercado mundial (centavos de dólar por libra-peso) e relação estoque/consumo em \%. 1980 a 1993. (Dados da Sugar and Sweetener/USDA, 1994). 
O mercado internacional do açúcar conta com a participação de aproximadamente 120 países produtores, o que pode ser considerado um número bastante grande sendo justificado por alguns autores pela busca da auto-suficiência de vários países. Essa busca teria se intensificado após o final da Segunda Guerra Mundial, segundo alguns autores, entre os quais Jank (1988). A Tabela 5 apresenta os principais países produtores e consumidores mundiais de açúcar para o período 1990/91 a 1994/95.

Tabela 5 - Principais paises produtores e consumidores de açúcar. Média dos últimos anos para quantidades produzidas e consumidas (em açúcar bruto ${ }^{6}$ )

\begin{tabular}{cccc}
\hline $\begin{array}{c}\text { PAÍSES } \\
\text { PRODUTORES }\end{array}$ & $\begin{array}{c}\text { PRODUÇÃO } \\
\text { (Milhões de toneladas) } \\
(1990 / 91-1994 / 95)\end{array}$ & $\begin{array}{c}\text { PAÍSES } \\
\text { CONSUMTDORES }\end{array}$ & $\begin{array}{c}\text { CONSUMO } \\
\text { (Milhões de toneladas) } \\
(1990 / 91 \text { - 1993/94) }\end{array}$ \\
\hline UE & 16,61 & UE & 13,01 \\
Índia & 13,48 & Índia & 13,20 \\
Brasil & 9,44 & EUA & 8,13 \\
EUA & 6,76 & China & 7,81 \\
China & 7,37 & Brasil & 7,22 \\
Austrália & 4,11 & Federação Russa & 5,79 \\
Ucrânia & 4,30 & México & 4,40 \\
Tailândia & 4,29 & Paquistão & 2,56 \\
Cuba & 5,28 & Indonésia & 2,55 \\
México & 3,93 & Japão & 2,72 \\
Total Mundial & 113,77 & Total Mundial & 114,00 \\
\hline
\end{tabular}

Fonte: Sugar and Sweetener (USDA), Set./1994.

${ }^{6} \mathrm{O}$ açúcar bruto, terminologia utilizada nas publicações internacionais, engloba segundo a FAO o açúcar não refinado, portanto, considera-se pelos padrões brasileiros que se refere aos tipos demerara e cristal. $O$ uso de coeficientes para transformar outros tipos de açúcar em açúcar bruto é um artifício que permite expressar as quantidades em açúcar total. No Brasil é mais comum utilizar o equivalente demerara, ou seja, as quantidades de diferentes tipos de açúcar cristal e refinado são transformadas através de coeficientes para obter seu valor total em quantidade de demerara. Essa diferença de terminologia pode estar associada às características distintas de produção entre países.

${ }^{7}$ Inclui os seguintes países: França, Itália, Reino Unido, Espanha, Bélgica-Luxemburgo, Portugal, Holanda, Alemanha, Dinamarca, Grécia, Irlanda. 
Os três maiores produtores mundiais de açúcar, União Européia, Índia e Brasil destacam-se também como os maiores consumidores. Os três produziram juntos quase $35 \%$ da produção total mundial e consumiram aproximadamente $30 \%$ do total consumido nesse período analisado.

$\mathrm{O}$ açúcar pode ser originado tanto da cana-de-açúcar quanto da beterraba açucareira, com mais de $60 \%$ da produção mundial sendo do primeiro tipo. Quanto aos custos de produção, em média, segundo dados do USDA, o custo da tonelada de beterraba, para o ano de 1992, foi $47 \%$ mais alto que o da tonelada da cana. Os países da União Européia são basicamente produtores de açúcar de beterraba, cuja produção cresceu bastante nas últimas décadas viabilizada pelos elevados níveis de subsídios concedidos pelos seus governos. Os países em desenvolvimento, grandes produtores da África, Ásia, América do Sul e Central, e Austrália, destacam-se na produção do açúcar a partir da cana-de-açúcar. Os EUA, por sua vez, produzem a partir dessas duas matériasprimas.

É interessante verificar o comportamento dos preços no mercado internacional do açúcar, observando o chamado ciclo do açúcar, que consiste na alternância das épocas de pico de preços com periodos de baixa, cuja duração média, segundo Abbott (1990), é de 6 a 9 anos. A Figura 7 apresenta a evolução dos preços internacionais para um período mais longo de tempo do que aquele apresentado na Figura 5, permitindo assim, observar melhor a presença do ciclo do açúcar.

Os picos observados em alguns anos são decorrentes de preços baixos em um período anterior. Preços descendentes provocam a contração da produção e a escassez no mercado. Por sua vez, essa redução da quantidade de açúcar no mercado, leva à alta de preços que estimula a expansão da produção e novos investimentos. Isso resulta em superprodução e preços baixos, num periodo seguinte, completando-se o ciclo. No ano de 1974, o preço no mercado internacional de açúcar atingiu o máximo valor ao longo do período analisado, em decorrência não só desse ciclo mas também da crise de petróleo que se fez refletir nas cotações das commodities agricolas. Contexto semelhante foi responsável pelo pico de preços no ano de 1980. 


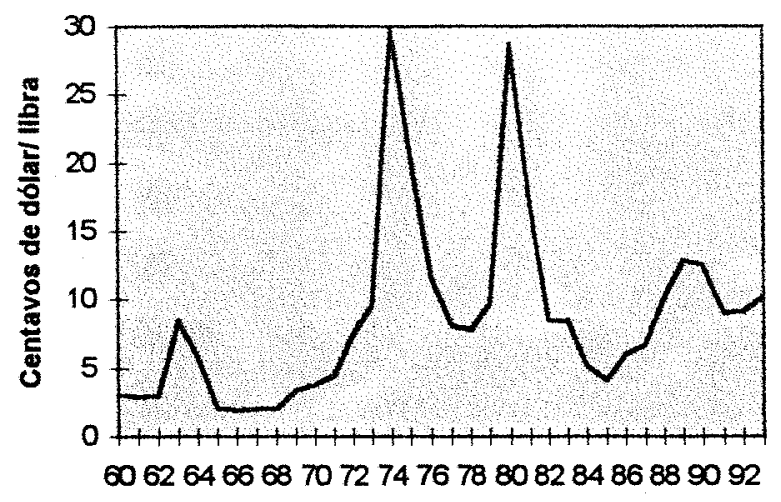

ANO

Figura 7 - Preços do açúcar demerara no mercado mundial livre (Preço ISA, International Sugar Agreement, uma média do spot do Contrato n 11 de Nova Iorque e do preço FOB diário de Londres, para os portos do Caribe. 1960-1992. Fonte: Abbott (1990).

Borrell \& Duncan (1992) estimaram, para o período entre 1982 e 1988, que as políticas européia, norte-americana e japonesa, conjuntamente, contribuíram para deprimir os preços mundiais em $33 \%$ e para aumentar a sua variabilidade em $28 \%$, aumentando também a probabilidade de ocorrerem preços muito baixos.

A taxa de crescimento do consumo de açúcar nos países desenvolvidos vem se reduzindo desde a década de 80 . Essa tendência pode estar relacionada à baixa elasticidade-renda da demanda por açúcar nesses países (entre 0,1 e 0,2 nos Estados Unidos, Canadá e Europa Ocidental); ao nível de consumo per capita em países desenvolvidos, que se encontra próximo de seu ponto de saturação; e ao desenvolvimento de adoçantes alternativos (Abbott, 1990).

Nos países em desenvolvimento, o consumo per capita varia bastante. Alguns apresentam valores bastante elevados, como é o caso do Brasil e de Cuba, estimados, para 1986, em mais de $40 \mathrm{Kg} /$ habitante/ano, equivalendo ao consumo per capita de países da UE, Austrália e da ex-URSS. Outros, apesar de exportarem açúcar, apresentam valores baixos. É o caso da Índia e Tailândia, com 11,4 e 14,1 $\mathrm{kg} /$ habitante/ano, respectivamente, sendo praticamente o dobro da quantidade consumida 
na China. Há ainda países cujo consumo per capita é inferior a $5 \mathrm{~kg} / \mathrm{habitante} / \mathrm{ano}$, tais como Gana e Bangladesh. O consumo per capita médio mundial, para esse mesmo ano foi de $20,4 \mathrm{~kg}$ em equivalente bruto (Abbott, 1990).

O avanço dos adoçantes alternativos é uma questão importante para avaliar a evolução do consumo, e, portanto, do padrão de exportação mundial de açúcar. Nos EUA, os custos de produção do High Fructose Corn Syrup - HFCS, conhecido como xarope de milho, são relativamente baixos comparados ao preço subsidiado do açúcar. Esse fato impulsionou de tal modo a substituição do açúcar que, segundo dados de Borrell \& Duncan (1992), a participação do açúcar no mercado total de adoçantes norte-americano caiu de $79 \%$, em 1970 , para $41 \%$, em $1988^{8}$. Assim, conclui-se que o estímulo doméstico para produção de açúcar sob garantia de preço, e os aumentos na produção e uso de adoçantes derivados do milho contribuíram para reduzir a necessidade de importação de açúcar por esse País.

Do ponto de vista estrutural, outra característica importante do mercado de açúcar em vários países é a dependência da produção e da comercialização em relação às políticas governamentais. Existem estatísticas mostrando que em 1972 cerca de $80 \%$ do total mundial exportado foi negociado, direta ou indiretamente, através dos governos (Carvalho, 1986). No entanto, à semelhança do que ocorre no Brasil, a intervenção estatal vem diminuindo em outros países, enquanto que a participação das "tradings" vem se acentuando nos negócios internacionais. Em 1993, atuando juntamente com as unidades produtivas, as "tradings" responderam por $50 \%$ do açúcar exportado no mundo, e por $33 \%$ das importações. A presença direta dos governos nos negócios caiu de $48 \%$ para $34 \%$ nas exportações, e de $55 \%$ para $33 \%$ nas importações, no período de 1989 a 1993 (Gazeta Mercantil, 1995).

Essa intervenção no mercado de açúcar apresenta-se diferenciada, conforme o país e a matéria-prima da qual se origina. Por um lado, o açúcar produzido da

\footnotetext{
${ }^{8}$ Nos Estados Unidos, segundo Yarbrough \& Yarbrough (1991), os preços internos do açúcar, mantidos em niveis elevados artificialmente, encorajaram o desenvolvimento de produtos substitutos, principalmente pela necessidade crescente de atender à indústria. Segundo esses autores, nos últimos anos, ocorreu um aumento de $4 \%$ para $50 \%$ na parcela do mercado de adoçantes atendida pelos derivados de milho, valores próximos aos já apresentados no texto. Atualmente, o uso de substitutos do açúcar, principalmente o HFCS, tem se alastrado também no Canadá e Japão (Szmrecsányi, 1989).
} 
beterraba (geralmente nos paises desenvolvidos) é altamente subsidiado e sujeito a políticas protecionistas de controle de produção e de preços. Em contrapartida, a produção a partir da cana-de-açúcar, destacando-se os países menos desenvolvidos, está sujeita à taxação pelos próprios governos (geração de receitas), e também às restrições de importação, tarifárias e não tarifárias, adotadas pelos países mais desenvolvidos.

Borrell \& Duncan (1992) discutem que a preocupação em isolar os produtores da instabilidade dos preços no mercado de açúcar mundial, estimulou os países, mesmo aqueles com baixo custo, a interferirem no mercado. Países que exportam grande parte de sua produção são mais expostos a essas oscilações, e o contrário se verifica para aqueles cujo mercado doméstico é grande. Segundo os autores, nos países industriais as políticas adotadas para proteção do setor tiveram como meta manter um patamar estável de renda ao produtor. Acrescentam que no Japão e na Europa a autosuficiência também foi um fator considerado. Já nos países em desenvolvimento, as medidas intervencionistas geralmente foram associadas pelos autores à necessidade de acumular divisas estrangeiras.

O mercado de açúcar caracteriza-se por apresentar diferentes tipos de estruturas, conforme a abordagem de Abbott (1990). A primeira é a dos mercados controlados, englobando os Acordos Internacionais de Açúcar - AIAs, cuja finalidade é controlar e regulamentar as operações de mercado, visando principalmente torná-lo mais estável no que se refere aos preços. A formação de estoques reguladores e a fixação de cotas de exportação são os principais instrumentos utilizados com essa finalidade.

A segunda categoria compreende os mercados preferenciais e garantidos, incluindo os acordos bilaterais e especiais entre países importadores e exportadores. Esses acordos prevêem tratamento diferenciado, garantindo mercados para quantidades específicas, com qualidade, preços e datas de entrega pré-definidos. Os exemplos mais conhecidos são os arranjos entre Cuba e os países da Europa Oriental, e o Protocolo do Açúcar do Acordo de Lomé entre a União Européia (UE) e as suas ex-colônias da África, Caribe e Pacífico (ACP). Antes de 1974, cerca de 60\% de todas as exportações eram realizadas sob esses tipos de arranjos, geralmente originados a partir de relacionamentos históricos, políticos e ideológicos entre as partes negociadoras. 
O Mercado Livre Mundial seria um terceiro tipo de estrutura que se caracteriza pela instabilidade de preços, administrados através dos AIAs quando estão vigentes. Alguns estudiosos referem-se a essa parcela do mercado como a um resíduo, apesar de englobar, atualmente, a maior parte do produto comercializado no mercado internacional.

Tem-se verificado que os preços no mercado livre não guardam relação com os custos de produção, seja dos países exportadores ou dos importadores. Esses preços são determinados principalmente nas bolsas de commodities, conforme a demanda e a oferta. Geralmente são inferiores aos dos mercados preferenciais e sujeitos a grandes oscilações especulativas (Szmrecsányi, 1979).

No período entre 1974 e 1982, o mercado passou por transformações significativas com o término do U.S. Sugar Act e do Acordo do Açúcar da Commonwealth, bem como com a então chamada Comunidade Econômica Européia CEE, passando a desempenhar papel de exportador líquido ao invés de importador que fora até meados da década de 70. A UE é, atualmente, o maior exportador no mercado livre de açúcar (Tabela 6).

Analisando a estrutura do mercado, verifica-se na Tabela 6 que as exportações dos sete maiores exportadores têm se apresentado mais concentradas em relação ao total de exportações mundiais do que as importações dos sete maiores países importadores em relação às importações mundiais, durante o período 1990/1994. O mercado importador ainda é bastante pulverizado e alguns países são compradores esporádicos.

Nos Estados Unidos, um dos mercados mais regulamentados de açúcar do mundo, a política restritiva consiste, basicamente, em limitar o volume importado através de preços domésticos elevados e tarifas muito altas para quantidades acima das cotas estabelecidas. As cotas permitem importar com uma pequena tarifa, sendo que no caso do regime preferencial torna-se nula (para o Canadá e México, que compõem o Acordo Norte-Americano de Livre Comércio - NAFTA). O Brasil possui a segunda maior cota desse mercado (14,5\%), historicamente suprida pelos produtores do Nordeste (Camargo Neto, 1996). 
Tabela 6 - Principais paises exportadores e importadores de açúcar e quantidades comercializadas no mercado mundial, 1990-1994

\begin{tabular}{|c|c|c|c|c|}
\hline \multirow{3}{*}{$\begin{array}{c}\text { PAISES } \\
\text { EXPORTADORES }\end{array}$} & \multirow{2}{*}{\multicolumn{4}{|c|}{$\begin{array}{c}\text { ANO } \\
\text { (Milhões de toneladas em equivalente demerara) }\end{array}$}} \\
\hline & & & & \\
\hline & $90 / 91$ & $91 / 92$ & $92 / 93$ & $93 / 94$ \\
\hline Cuba & 6,80 & 6,10 & 3,80 & 3,20 \\
\hline UE & 5,58 & 4,88 & 5,58 & 6,33 \\
\hline Ucrânia & 3,45 & 1,50 & 2,00 & 1,80 \\
\hline Austrália & 2,82 & 2,35 & 3,48 & 3,49 \\
\hline Tailândia & 2,74 & 3,66 & 2,33 & 2,80 \\
\hline Brasil & 1,30 & 1,61 & 2,43 & 2,60 \\
\hline China & 0,32 & 1,42 & 2,10 & 0,80 \\
\hline Total mundial exportado & 32,47 & 30,71 & 29,55 & 29,48 \\
\hline $\begin{array}{c}\text { Participação dos sete países } \\
\text { nas exportações mundiais } \\
(\%)\end{array}$ & 69,88 & 70,07 & 73,50 & 71,98 \\
\hline \multicolumn{5}{|l|}{ IMPORTADORES } \\
\hline Federação Russa & 3,58 & 3,85 & 3,50 & 3,15 \\
\hline UE & 1,88 & 1,89 & 2,01 & 1,98 \\
\hline EUA & 2,57 & 2,00 & 1,83 & 1,65 \\
\hline Japão & 1,76 & 1,80 & 1,77 & 1,69 \\
\hline China & 1,06 & 1,23 & 0,51 & 0,60 \\
\hline Canadá & 1,11 & 0,96 & 1,01 & 1,13 \\
\hline República da Coréia & 1,23 & 1,26 & 1,23 & 1,26 \\
\hline Total mundial importado & 32,47 & 30,71 & 29,55 & 29,34 \\
\hline $\begin{array}{l}\text { Participação dos sete países } \\
\text { nas importações mundiais } \\
(\%)\end{array}$ & 40,62 & 42,30 & 40,14 & 39,06 \\
\hline
\end{tabular}

Fonte: Sugar and Sweetener - USDA, Sept./1994. 
A descrição do sistema europeu mostra que há garantias de preços superiores aos vigentes no mercado internacional para os fornecedores que detêm as cotas preferenciais. Segundo Camargo Neto (1996), esse regime foi reavaliado em 1995, permanecendo praticamente o mesmo, de forma que as cotas A e B fixam preços diferentes, apresentando uma dispersão elevada de tamanho, mesmo entre os paises da própria União Européia.

$\mathrm{O}$ açúcar que excede as cotas $\mathrm{A}$ e $\mathrm{B}$, chamado de $\mathrm{C}$, é liberado para comercialização aos niveis de preço do mercado externo, viabilizando as exportações para os produtores mais competitivos desse setor. A exportação de excedentes de cotas, segundo a mesma fonte, é uma política de subsídios, mesmo que implícitos, e sobre a qual a Rodada Uruguai do GATT não versa.

De modo geral, o nível de proteção nos países industrializados é bastante superior ao dos países da América Latina, para o caso do açúcar. Esse nível medido em termos de percentagem do valor do produto agrícola era de $70,121,115$ e 32, para os EUA, Japão, UE e América Latina, respectivamente, no período entre 1985 e 1987 (Garcia \& Sacristan, 1995). Borrell \& Duncan (1992) alertam que mais da metade da renda dos produtores de açúcar nos EUA, Japão e UE provém dos subsídios mantidos pelas políticas de açúcar.

Borrell \& Duncan (1992) apresentaram um modelo cujos resultados indicam que na ausência do controle dos governos, a produção se deslocaria dos países de custo elevado e produção subsidiada (especialmente, UE, EUA e Japão) para os países com custos menores (Austrália, Brasil e Tailândia). Os autores concluem que as políticas para o açúcar em países com custos elevados reduzem significativamente os preços mundiais no longo prazo e aumentam a sua variabilidade. Por outro lado, as políticas de controle adotadas nos países de baixo custo aumentam os preços mundiais e também contribuem para aumentar sua variabilidade.

O papel desempenhado, em periodo recente, na comercialização mundial de commodities pelas bolsas de mercadorias e de mercados futuros, onde os preços do mercado "spot" e futuros são estabelecidos, merece ser comentado. Segundo Rico (1992), os contratos comumente usados para o açúcar demerara são o Contrato nº 11 de 
Nova Iorque ou o Contrato $\mathrm{n}^{\mathrm{o}} 6$ de Londres, e para o açúcar refinado, utiliza-se o Contrato $n^{\circ} 5$ de Londres, ou os contratos negociados na Bolsa de Paris.

Recentemente, foi lançado um contrato para Açúcar Cristal Cambial na Bolsa de Mercados \& Futuros de São Paulo (BM\&F), que tem assumido uma importância relativamente limitada quanto ao volume total comercializado da commodity, o que possivelmente pode ser explicado pela pouca tradição desse tipo de mercado no contexto nacional. A vantagem desse contrato para o açúcar cristal é que consiste numa forma de melhorar suas condições de comercialização.

\subsection{Fatores determinantes das exportações de açúcar pelo Brasil}

Como já foi discutido brevemente na introdução deste trabalho, a posição de um país exportador diante do mercado mundial é resultante de fatores que definem a oferta e a demanda interna e externa pelo produto como por exemplo, os relacionamentos históricos entre países, os acordos institucionais, as preferências dos consumidores, as políticas comerciais dos países fornecedores e a confiabilidade do exportador, entre outros.

No que se refere ao Brasil, alguns fatores têm sido considerados determinantes da produção e da exportação de açúcar e do seu desempenho no mercado internacional nos últimos anos. Szmrecsányi (1989) acredita que para os países exportadores de açúcar, os níveis de estoques assim como os preços do açúcar nos principais mercados de commodities têm significado limitado, tanto para produtores quanto para consumidores. $\mathrm{Na}$ realidade, a demanda e a oferta local do produto e as regulamentações às quais estão sujeitos são mais importantes, segundo esse autor.

O papel do Estado também é enfatizado por Borrell (1991) dado que a intervenção na produção e comercialização de cana, açúcar e álcool prevalecem. $\mathrm{O}$ autor conclui que alterações nos preços mundiais de açúcar e de petróleo não têm efeito direto sobre a produção e consumo de açúcar no Brasil. Considera, assim, que o sistema de cotas estabelecido pelo governo constitui-se no principal determinante da produção brasileira. No entanto, analisando periodo mais recente, Burnquist \& Bacchi (1994) consideram que o nível das exportações brasileiras de açúcar na safra 1993/94 esteve 
relacionado aos preços internacionais de açúcar e petróleo, muito mais do que ao nível doméstico de sua produção.

$\mathrm{Na}$ análise dos impactos causados por novas políticas comerciais, domésticas e mundiais, sobre a oferta e demanda do açúcar brasileiro em um mercado é necessário conhecer a posição do País frente ao mercado internacional. Lemos (1983), utilizando análise espectral para estudar ciclos de preços de alguns produtos agrícolas, entre os quais o do açúcar, mostrou que, na maior parte do período entre 1827 e 1980, o Brasil foi "tomador de preços"" nesse mercado. Borrell (1991), em trabalho mais recente, sugere que o Brasil tem capacidade de influenciar os preços mundiais, principalmente no curto prazo.

É importante lembrar que, mesmo quando um determinado país é um "tomador de preços", sua participação no mercado pode apresentar-se bastante superior à dos demais países sob condições semelhantes. Existem, portanto, diferentes graus de participação e influência de um país sobre o mercado, sendo que esses nem sempre são captados pelos testes estatísticos utilizados (Almeida \& Mesquita, 1995). Diante dos volumes de açúcar produzidos e exportados pelo Brasil é razoável admitir que o País possa vir a assumir no futuro um papel determinante na formação dos preços nesse mercado.

O conhecimento da elasticidade-preço da demanda de exportação é importante para a determinação dos resultados finais em termos de saldo comercial, principalmente diante de situações de instabilidade na oferta. A estabilidade de preços e de receitas para o Brasil, como exportador de açúcar, é relevante para este estudo. Stern ${ }^{10}$ citado por Carvalho (1986) menciona que países exportadores de produtos cuja oferta tem comportamento instável, estão mais sujeitos a grandes variações nas suas receitas de exportação.

\footnotetext{
${ }^{9}$ Outros resultados interessantes obtidos pelo autor foram que o açúcar apresenta um ciclo médio de preços de 2 a 3 anos, tempo este justificado pela defasagem de resposta da oferta às alterações, além de concluir que são necessários pelo menos dois anos para que as exportaçães brasileiras respondam aos preços internacionais.

${ }^{10}$ Stern, R. M. World market instability in primary commodities. Banca Nazionale del Lavoro Quarterly Review, Roma, n.117, p. 175-95. June 1975.
} 
Igualmente importante é a avaliação dos efeitos das alterações no mercado (mudanças nas preferências, medidas de desregulamentação das políticas domésticas e de liberalização comercial, entre outros) sobre o comportamento da oferta mundial agregada e da oferta individual de países influentes no mercado de açúcar.

Segundo Szmrecsányi (1979), a oferta mundial e seu crescimento têm se mostrado superiores à correspondente demanda de açúcar. Isso resulta não só das políticas de protecionismo e da promoção da auto-suficiência, mas também da existência de países que devido à dependência do açúcar como fonte de divisas, promovem o aumento de suas exportações mesmo em situações desfavoráveis de preços. Esse comportamento, segundo o autor, pode gerar o aumento de oferta sem a contrapartida da demanda.

A situação descrita acima é passível de ser avaliada pelas elasticidadespreço de oferta de açúcar e de suas matérias-primas. Tais coeficientes, no caso da cana, tendem a ser mais baixos do que para a beterraba no curto-prazo, devido a sua característica de cultura semi-perene. Segundo Szmrecsányi (1979), a elasticidade preço da oferta da cana no Brasil é pequena, sendo aproximadamente 0,115 no curto prazo e 0,124 no longo prazo, o que se deve ao controle do Estado no setor. No Brasil, é necessário ainda ressaltar que grande parte da cana processada pertence às próprias indústrias é a chamada cana própria. $\mathrm{Na}$ Índia, esses valores chegam a 0,340 e 0,600 , respectivamente.

Borrell (1991), analisando o mercado de açúcar brasileiro, ressalta que dada a intervenção dos governos nos mercados domésticos de açúcar, ao menos no curto prazo, sua produção e consumo tornaram-se relativamente insensíveis às mudanças nos preços mundiais. No longo prazo, mesmo em economias onde o setor é controlado (isolando parcialmente produtores e consumidores das oscilações do mercado internacional), os consumidores e produtores respondem, embora mais lentamente, às mudanças de preços do mercado. Dessa forma, o impacto de um possível choque brasileiro de oferta (um acréscimo) é amenizado pelo ajuste dos outros paises em seus respectivos niveis de produção. 
Borrell (1991), admitindo que os produtores brasileiros não são livres para responder aos estímulos internacionais de preços, e usando simulações de choques para o período de 1985 a $2004^{11}$, estimou elasticidades-preço da demanda de exportação para o açúcar entre $-3,5$ a $-3,2$. Isso implica que a cada $1 \%$ de aumento nas exportações brasileiras, o preço mundial teria um decréscimo de $0,29 \%$ a $0,31 \%$. Esse resultado foi obtido quando o choque de oferta foi simulado para ocorrer em 1985 (ano de preços baixos). Quando o ano do choque foi 1992, início de uma alta de preços, o impacto foi menor, obtendo-se elasticidade de $-4,4$, implicando que a cada $1 \%$ de aumento no volume exportado, o preço mundial cai $0,23 \%{ }^{12}$.

$\mathrm{O}$ autor conclui que apesar da possibilidade do Brasil afetar os preços mundiais no curto prazo, o mesmo não se verifica para o longo prazo. Sua influência é insuficiente para que possa aumentar sua receita total com as exportações através da redução das cotas de exportação. Para que isto seja possível, a elasticidade deve estar compreendida entre $-1 \leq e \leq 0$, ou seja, caracterizando uma curva inelástica de demanda por exportações.

Segundo os resultados obtidos através de simulações, Borrell (1991) concluiu que o aumento das exportações brasileiras através da imposição de cotas têm um impacto mais negativo sobre os preços internacionais do que quando esse aumento é promovido pelo produtor em resposta direta aos preços do mercado (na situação de inexistência do sistema de cotas).

As conclusões do trabalho acima incluem, ainda, a perspectiva de que o País pode aumentar a estabilidade dos preços mundiais, permitindo aos produtores flexibilizar a produção, de forma que a remoção dos controles de produção existentes poderia gerar ganhos econômicos significativos (em termos de aumentos das exportações brasileiras).

\footnotetext{
${ }^{11}$ Nos resultados da simulação, aumentos sustentados (através de cotas autorizadas) nas quantidades de $0,5,2,0$ e 6,0 milhões de toneladas de açúcar traduziram-se, respectivamente, em aumentos médios de $8,3 \%, 32,6 \%$ e $96,1 \%$ nas exportações brasileiras.

${ }^{12}$ As transformações de elasticidade-preço para impacto sobre preços podem ser feitas sob determinadas condições descritas por Houck, Journal of Farm Economics, v. 47, 789-793, 1965. Ver também Barros (1987, p. 237-241).
} 
Outros autores estudaram o mercado de exportação de açúcar, estimando elasticidades-preço de oferta e demanda para o Brasil. Os resultados de alguns trabalhos anteriores sobre o assunto encontram-se resumidos na Tabela 7. Observa-se que as estimativas de elasticidades de demanda por exportação diferem bastante. Esse fato indica a necessidade de desenvolver novas pesquisas com objetivos de avaliar o desempenho do País neste mercado, principalmente porque, recentemente, as políticas para o setor sucroalcooleiro brasileiro têm sido modificadas no sentido da desregulamentação.

Tabela 7 - Elasticidades-preço da demanda e da oferta de exportação brasileira de açúcar, segundo vários autores

\begin{tabular}{lcc}
\hline \multicolumn{1}{c}{ Autor/Período } & $\begin{array}{c}\text { Elasticidade-preço da demanda de } \\
\text { exportação }\end{array}$ & $\begin{array}{c}\text { Elasticidade-preço da oferta de } \\
\text { exportação }\end{array}$ \\
\hline $\begin{array}{l}\text { Barros et al. (1977) } \\
1947 \text { a } 1973\end{array}$ & $-1,25 ;-1,65^{*}$ & 0,628 \\
Carvalho (1986) & $-0,153^{*}$ & $0,260^{*}$ \\
1961 a 1984 & \\
Borrell (1991) & & - \\
1985 a 2004 & $-3,5$ a $-3,2$ & \\
\hline
\end{tabular}

* Refere-se a estimativas de longo prazo.

\subsection{A diferenciação de produtos no comércio internacional e a definição de competitividade}

Neste sub-ítem considera-se a importância das pressuposições de homogeneidade dos produtos, preliminares à discussão da metodologia no próximo capítulo.

No estudo do comércio internacional, é comum adotar-se a pressuposição simplificadora de que os produtos são homogêneos $e$, consequentemente, substitutos perfeitos. Outra alternativa é considerar que os produtos importados diferenciam-se em função da qualidade, país de origem, crédito, idioma, arranjos políticos e institucionais (Fontes et al., 1989). Esses autores mencionam que desde o desenvolvimento dos 
modelos de Armington ${ }^{13}$, do Fundo Monetário Internacional (FMI), cuja aplicação mais usual é a previsão de fluxos multilaterais de comércio, a diferenciação pela origem dos produtos nas exportações agrícolas tem sido abordada com maior ênfase.

Johnson et al. (1979) acreditam na diferenciação dos produtos por parte dos países importadores, seja em função de suas características físicas, seja pela natureza do país ofertante. $\mathrm{Na}$ tentativa de explicar a razão dos diferenciais existentes nos preços de um mesmo produto, dois modelos foram discutidos por esses autores. Primeiramente, empregou-se o modelo da distribuição espacial de preços, argumentando que a diferença de preços do produto de um determinado ofertante nos diferentes mercados importadores está baseada nos custos de transferência (envolvendo transporte, margens de mercado e barreiras comerciais estabelecidas pelos governos). Os autores ressaltaram que o modelo de preços espaciais não explica por que se observam preços relativos não unitários entre bens ofertados por países diferentes, comercializados no mesmo mercado consumidor, e nem mesmo os motivos que provocam o cross-hauling (importação e exportação de um mesmo bem por um dado país).

O segundo modelo proposto na análise de Johnson et al. (1979) é o dos preços relativos de produtos similares mas provenientes de origens diferentes, e comercializados em um mesmo mercado geográfico. Nesse caso, a justificativa para preços relativos não unitários é que os bens ofertados por diferentes países são diferenciados do ponto de vista dos importadores. Essa diferenciação pelo consumidor pode estar relacionada a características que não são intrínsecas ao bem, e sim a fatores como a confiabilidade entre as partes envolvidas, facilidade de crédito, tradição de relacionamentos e rotas mais favoráveis de transporte, entre outros.

Richardson ${ }^{14}$ criticou a crença de alguns pesquisadores de que a característica de não-homogeneidade no caso dos produtos manufaturados, seria mais relevante do que nos produtos agrícolas. $\mathrm{O}$ autor argumenta que mesmo para produtos agricolas funcionalmente homogêneos, a interferência governamental sobre a oferta de

\footnotetext{
${ }^{13}$ Armington, P.S. A theory of demand for products distinguished by place of production. IMF Staff Papers, v.16, p.159-178. Mar.1969

${ }^{14}$ Richardson, J.D. Some empirical evidence on commodity arbitrage and the Law of One Price. Journal of Int. Econ., v. 8, p. 341-352. Mav 1978.
} 
exportação e a alternância ou não coincidência dos periodos de safra entre paises são dois dos fatores que podem causar a sua diferenciação diante dos importadores. Telser ${ }^{15}$ acrescenta ainda que a diferença nos preços entre bens homogêneos pode estar relacionada aos custos de obter as informações sobre os mesmos (Johnson et al., 1979).

Ainda sobre a questão dos preços diferenciados, Richardson realizou uma análise econométrica sofisticada desses preços visando testar a "Lei do Preço Único", concluindo que se rejeita a perfeita arbitragem das commodities para qualquer tipo de bem, sendo que todos os produtos de um país podem ser considerados como diferenciados de todos os mesmos produtos de uma outra nação (Johnson et al., 1979).

$\mathrm{O}$ modelo de elasticidade de substituição tem sido usado frequentemente em estudos que pressupõem diferenciação de produtos (Fontes et al. 1989; Fontes \& Ferrão, 1990; Silva, 1992; Vasconcelos, 1994). Johnson et al. (1979) consideram que os modelos de elasticidade de substituição empregados nas relações básicas de demanda são adequados para lidar com bens diferenciados pela origem.

Fleming \& Tsiang (1956), estudando o comportamento de exportações, avaliaram até que ponto variações na competitividade de um país podem explicar alterações na participação do mesmo como exportador mundial de manufaturados e, para tanto, utilizaram alguns índices de preços. Consideraram que as variações dependem também de mudanças nas condições de demanda mundial. Esses autores apresentaram uma discussão bastante abrangente sobre causas de variação nas exportações dos países, da qual alguns aspectos interessantes são apontados a seguir.

Mudanças em competitividade podem ser atribuídas a: (i) taxas diferentes de crescimento da produtividade em países distintos; (ii) mudanças nas taxas de câmbio; (iii) mudanças nas taxações ou subsídios de exportação; (iv) taxas diferentes de aumento dos níveis nacionais de preços; (v) taxas diferentes da melhoria na qualidade de bens exportados e taxas diferentes de desenvolvimento de novos produtos de exportação; (vi) taxas diferentes de aperfeiçoamento na eficiência de comercialização; e, (vii) diferencial na capacidade de atender prontamente às encomendas. Verifica-se que as quatro primeiras razões estão relacionadas diretamente aos preços.

\footnotetext{
${ }^{15}$ Telser. L. Searching for the lowest price. Amer. Econ. Rev., v. 63, p. 40-49. May 1973.
} 
As condições de demanda são importantes para a análise dos fluxos de comércio de um país. Desde que os países exportadores se especializem, até certo ponto, em diferentes tipos de bens exportáveis, a mudança na composição de bens demandados pelos importadores em qualquer mercado, tenderá a alterar a participação de paises exportadores no volume agregado de exportáveis para aquele mercado (Fleming \& Tsiang, 1956).

Os autores mencionados ressaltaram, ainda, a importância da substituição de bens exportáveis de um país por produtos de outro. Dessa forma, o resultado final para o país exportador depende também da competitividade de seus concorrentes, além da sua própria.

A conceituação do termo "competitividade" deve ficar explícita nos estudos que envolvem o comércio internacional, antes de apresentar-se o procedimento metodológico que será adotado. Segundo Fleming \& Tsiang (1956) "pode-se considerar que a competitividade de um pais em determinado mercado aumenta quando o volume de suas exportações para aquele mercado, relativamente ao volume de outros paises exportadores tende a aumentar como resultado de mudanças nas condições de oferta de exportação".

Não há um consenso mais rigoroso em termos da definição de competitividade na literatura. Horta et al. ${ }^{16}$ citado por Carvalho (1995) apresentam três linhas conceituais relacionadas com a competitividade internacional e discutem as dificuldades envolvidas na escolha de um ou de outro indicador. $O$ conceito segundo o enfoque do "desempenho" associa a competitividade do país diretamente ao seu desempenho no mercado internacional; o conceito "macro" considera variáveis relacionadas com decisões políticas, como subsídios e taxas de câmbio, e o conceito de "eficiência" reflete características estruturais da economia (aumentos de produtividade).

Dentre os principais problemas relacionados com esses indicadores de competitividade, estão a impossibilidade de explicitar os fatores explicativos da competitividade (conceito desempenho), a ambiguidade dos resultados obtidos a partir de

\footnotetext{
${ }^{16}$ Horta et al. Fontes de crescimento das exportações brasileiras na década de 80. Perspectiva da economia brasileira. Rio de janeiro, IPEA, v.1, cap. 12, p. 231-246. 1993.
} 
séries longas de tempo (conceito macro) e a dificuldade de construção de indicadores apropriados (conceito eficiência).

Carvalho (1995), avaliando as exportações agroindustriais do Brasil, adotou o conceito "desempenho" para a análise da competitividade internacional de forma que o efeito foi quantificado sem envolver a identificação dos fatores responsáveis por esse indicador. Essa identificação pode ser realizada na discussão dos resultados a partir da observação da ocorrência de fatores econômicos internos e externos que se relacionam ao ganho ou perda de competitividade do país no mercado internacional. 


\section{MATERIAL E MÉTODOS}

\subsection{Modelos baseados em análise de " market-share"}

A primeira parte deste capítulo consiste numa revisão sobre alguns modelos baseados em análise de "market-share", procurando abordar as diferenças existentes entre eles, suas vantagens e as críticas a que estão sujeitos. Inicialmente, desenvolve-se o modelo mais simples que serviu de base para os trabalhos posteriores, o "Constant market-share" (CMS), ou Modelo da Participação Constante ${ }^{17}$. Na sequência, são discutidos os trabalhos de alguns autores que utilizaram o CMS ou modelos que incorporaram peculiaridades ao modelo básico. A discussão inclui alternativas a essa abordagem baseadas em informações contidas nas matrizes de importação e exportação.

Diversos trabalhos utilizaram esse modelo para analisar a evolução das exportações de produtos importantes na pauta de exportação do Brasil, aplicando-se tanto a bens agricolas como industriais. Destacam-se, entre outros: Carvalho et al. (1991) para cacau; Carvalho et al. (1988) para açúcar; Horta (1983), Gonçalves (1987), Horta et al. (1993) e Almeida (1993), citados por Carvalho (1995); e Vasconcelos (1994), esse último enfocando o complexo da soja.

Os modelos de "market-share" geralmente têm como objetivo avaliar a participação de um país no fluxo mundial de comércio, bem como a desagregação das tendências de crescimento das exportações ou importações de acordo com os efeitos que as originaram. Geralmente constituem-se em estudos exploratórios sobre a evolução das

\footnotetext{
${ }^{17}$ O modelo CMS foi aplicado pela primeira vez para analisar o padrão de crescimento de exportações por Tysynski (1951), citado por Richardson (1971), sendo que há uma variante desse modelo, utilizada nos estudos de crescimento regional, conhecida como análise "shift and share".
} 
exportações e suas causas, tanto no que tange a fatores estruturais do país ou a sua competitividade.

O pressuposto básico deste método de análise, segundo Leamer \& Stern (1970), é o de que a participação de um país no mercado mundial permanece constante. A diferença entre o crescimento das exportações, calculado supondo "market-share" constante (CMS) e o crescimento efetivo (real) é atribuida ao efeito competitividade, relacionado a mudanças nos preços relativos.

Além disso, para o desenvolvimento das abordagens metodológicas que se seguem também fica implícita a pressuposição de que a oferta mundial de exportação do bem analisado é infinitamente elástica, à semelhança do que foi proposto por Konandreas \& Hurtado (1978, p. 22). Leamer \& Stern (1970, p. 28-36) discutem os problemas que tornam necessária a adoção dessa pressuposição.

Partindo-se do princípio de que é a relação de preços que determina a escolha pelo mercado importador entre dois produtos oriundos de dois países exportadores e competidores no mercado internacional, a demanda nesse mercado consumidor pelos dois produtos pode ser assim representada:

$$
\frac{q_{1}}{q_{2}}=f\left(\frac{p_{1}}{p_{2}}\right), \quad \text { com } \mathrm{f}^{\prime}<0
$$

A eq. (1) consiste, na sua essência, da própria relação básica da elasticidade de substituição, sendo $q_{1}$ e $q_{2}$ as quantidades vendidas pelos ofertantes 1 e 2 , e $p_{1}$ e $p_{2}$, seus respectivos preços. Multiplicando-se a função acima pelo termo $p_{1} / p_{2}$ e rearranjando os termos ${ }^{18}$ de forma a representar a mesma relação em forma de "marketshare", chega-se a:

$$
\frac{p_{1} q_{1}}{p_{1} q_{1}+p_{2} q_{2}}=g\left(\frac{p_{1}}{p_{2}}\right), \quad \text { com } \mathrm{g}^{\prime}<0
$$

\footnotetext{
${ }^{18}$ Para mais detalhes, ver Leamer \& Stern (1970), p.171-173.
} 
Essa expressão evidencia que o "market-share" do país 1 permanece constante a menos que a relação de preços $\left(\mathrm{p}_{1} / \mathrm{p}_{2}\right)$ varie, representando o princípio do "market-share" constante para um determinado período de tempo.

Segundo Carvalho (1995), o efeito competitividade quando atribuído apenas a mudanças nos preços relativos, leva a concluir que os importadores tendem a substituir o consumo dos bens cujos preços se elevaram por aqueles cujos preços tornaram-se relativamente mais baixos. Fleming \& Tsiang (1956) discutem, no entanto, que variações nos preços relativos não explicam totalmente as mudanças na competitividade.

As três razões propostas por Leamer \& Stern (1970) para que o crescimento efetivo das exportações de um país não acompanhe a média mundial são:

(i) Concentração das exportações em commodities cuja demanda cresça mais lentamente do que a média dos produtos (efeito composição das commodities);

(ii) Exportações destinadas principalmente a regiões estagnadas (efeito distribuição de mercado);

(iii) O país é incapaz ou não deseja competir efetivamente com outros ofertantes (efeito competitividade).

A desagregação matemática do crescimento das exportações nesses efeitos foi sugerida por Leamer \& Stern (1970) conforme o modelo descrito abaixo, que considera as exportações de um determinado bem $\mathbf{i}$, originadas de um país $\mathbf{A}$ e com destino a um país $\mathbf{j}$, utilizando dados de valores de exportações. Dadas as definições abaixo:

$\mathrm{V}_{\mathrm{i}}=$ valor das exportações do bem i pelo país $\mathbf{A}$, no periodo 1 ;

$\mathrm{V}^{\prime}{ }_{i}=$ valor das exportações do bem i pelo país $\mathbf{A}$, no período 2;

$\mathrm{V}_{\mathrm{j}}=$ valor das exportações do país $\mathbf{A}$ para o país $\mathbf{j}$, no periodo 1;

$\mathrm{V}_{\mathbf{j}}=$ valor das exportações do país $\mathbf{A}$ para o país $\mathbf{j}$, no periodo 2;

$\mathrm{V}_{\mathrm{ij}}=$ valor das exportações do bem i pelo país $\mathbf{A}$ para o pais $\mathbf{j}$, no período 1;

$r=$ aumento percentual no total mundial de exportações do período 1 para o 2;

$r_{i}=$ aumento percentual nas exportações do bem $\mathbf{i}$ do periodo 1 para o 2; 
$\mathrm{r}_{\mathrm{ij}}=$ aumento percentual nas exportações mundiais do bem $\mathbf{i}$ para o pais $\mathbf{j}$, do período 1 para 02.

Segue-se que para o período 1 tem-se:

$$
\sum_{j} V_{i j}=V_{i}
$$

De modo semelhante, para o periodo 2 tem-se:

$$
\sum_{j} V_{i j}^{\prime}=V_{i}^{\prime} \quad \sum_{i} V_{i j}^{\prime}=V_{j}^{\prime}
$$

sendo $\mathrm{i}=$ bens comercializados pelo país $\mathbf{A}$;

$\mathrm{j}=$ países importadores.

O valor total das exportações do pais A no período 1 é dado por:

$$
\sum_{i} \sum_{j} V_{i j}=\sum_{i} V_{i}=\sum_{j} V_{j}=V
$$

Os componentes do crescimento das exportações podem ser analisados desagregando-os, passo a passo, de forma que a análise em primeiro nível é aquela na qual se consideram que as exportações são completamente indiferenciadas quanto ao bem e quanto à região de destino. Ou seja, as exportações são consideradas como um único bem destinado a um único mercado. Presume-se que se $\mathbf{A}$ mantiver sua participação no total mundial, as suas exportações crescem em rV, ou seja, o total exportado pelo país $\mathbf{A}$ no período 1 , multiplicado pelo aumento percentual nas exportações totais mundiais entre os periodos 1 e 2 :

$$
V^{\prime}-V \equiv r V+\left(V^{\prime}-V-r V\right)
$$

A equação de primeiro nível (5) divide o crescimento das exportações do país A em uma parcela devida ao aumento geral mundial das exportações e outra devida a um resíduo não explicado, denominado de "efeito competitividade". 
Considerando que as exportações compreendem um conjunto variado de $\mathbf{i}$ bens, e que a eq. (1) refere-se a uma classe específica de commodity, procede-se a uma análise de segundo nivel. A eq. (5) é modificada, sendo que para o i-ésimo bem ela passa a ser representada como:

$$
\begin{gathered}
\mathrm{V}_{\mathrm{i}}^{\prime}-\mathrm{V}_{\mathrm{i}} \equiv \mathrm{r}_{\mathrm{i}} \mathrm{V}_{\mathrm{i}}+\left(\mathrm{V}^{\prime}{ }_{\mathrm{i}}-\mathrm{V}_{\mathrm{i}}-\mathrm{r}_{\mathrm{i}} \mathrm{V}_{\mathrm{i}}\right) \\
\mathrm{V}^{\prime}-\mathrm{V} \equiv(\mathrm{rV})+\sum_{i}\left(r_{i}-r\right) V_{i}+\sum_{i}\left(V_{i}^{\prime}-V_{i}-r_{i} V_{i}\right) \\
\Downarrow \\
\Downarrow
\end{gathered}
$$$$
\text { (a) (b) (c) }
$$

A equação (7) representa a desagregação num segundo nivel, onde o crescimento das exportações é resultado de três efeitos: (a) o crescimento geral das exportações mundiais; (b) a composição de bens das exportações de $\mathbf{A}$ no período 1; e (c) um resíduo que indica a diferença entre a variação efetiva e a variação esperada nas exportações de cada grupo de bens.

$\mathrm{O}$ efeito composição (b) indica até que ponto as exportações de $\mathbf{A}$ concentram-se em classes de bens para as quais as taxas de crescimento apresentam-se mais favoráveis do que a média mundial. Quando o termo $\left(r_{i}-r\right)$ é positivo, depreende-se que as exportações do país $\mathbf{A}$ concentram-se em bens cujos mercados crescem mais rapidamente do que a média dos demais.

No terceiro nivel da análise, Leamer \& Stern (1970) assumem que as exportações são diferenciadas por destino e pelo tipo de commodity comercializada. De forma análoga a (5) e (6) tem-se que:

$$
V^{\prime}{ }_{i j}-V_{i j} \equiv r_{i j} V_{i j}+\left(V^{\prime}{ }_{i j}-V_{i j}-r_{i j} V_{i j}\right)
$$

desagregando-se os termos da eq. (8), resulta na identidade (9): 


$$
\begin{aligned}
& V^{\prime}-V \equiv r V+\sum_{i}\left(r_{i}-r\right) V_{i}+\sum_{i} \sum_{j}\left(r_{i j}-r_{i}\right) V_{i j}+\sum_{i} \sum_{j}\left(V_{i j}^{\prime}-V_{i j}-r_{i j} V_{i j}\right) \\
& \Downarrow \quad \Downarrow \quad \Downarrow
\end{aligned}
$$
(a')
(b')
(c')

Assim, a identidade acima mostra que uma variação positiva ou negativa nas exportações pode resultar da soma dos seguintes efeitos:

(a') crescimento das exportações do país $\mathbf{A}$ devido ao crescimento mundial de exportações;

(b') crescimento devido à composição dos bens de exportação do país $\mathbf{A}$;

(c') crescimento devido à distribuição do mercado de exportação do país A. Essa parcela será positiva se A concentrar suas' exportações para mercados com crescimento relativamente rápido; $\mathrm{e}$

(d') resíduo que reflete a diferença entre o crescimento efetivo das exportações e o crescimento que teria ocorrido nas exportações do país $\mathbf{A}$, se a porcentagem de exportação de cada bem, para cada país, tivesse sido mantida. É chamado resíduo de competitividade.

A interpretação desse resíduo é que se ocorrer um valor negativo $\left(d^{\prime}<0\right)$ estará refletindo o fracasso do país em manter o seu "market-share". Assim, se a demanda pela exportação for descrita pela eq. (1) então considera-se que o resíduo de competitividade estará associado a um aumento dos preços relativos $\left(\mathrm{p}_{1} / \mathrm{p}_{2}\right)$ entre diferentes ofertantes. No entanto há fatores, além dos preços relativos, que podem interferir na atratividade relativa pelas exportações de um determinado país, e que podem estar compreendidos dentro do resíduo de competitividade embora não estejam explícitos.

Dentre esses fatores destacam-se as seguintes taxas diferenciais relativas a: (i) melhoria de qualidade e do desenvolvimento de novas exportações; (ii) incremento na eficiência do "marketing" ou em termos de financiamento das operações de venda; (iv) habilidade para atender com prontidão às encomendas dos importadores (Leamer \& Stern, 1970). 
Os determinantes discutidos até este ponto relacionam-se à demanda embora o resíduo de competitividade seja resultante da interação dos fatores de demanda e de oferta. No entanto, segundo Leamer \& Stern (1970), a análise de séries temporais da demanda dificilmente permite isolar essa origem dos efeitos. Na realidade, alguns fatores são reconhecidos por terem influência sobre o preço de oferta das exportações de um país comparado ao de seus competidores. Dentre esses os autores destacam: taxas de crescimento dos fatores produtivos disponiveis; resposta da oferta doméstica e da exportação a essas alterações; taxas de produtividade; características dos mercados importadores quanto ao seu crescimento; e taxa de inflação monetária.

Youtopoulos \& Nugent ${ }^{19}$, citados por Carvalho et al. (1988), e Rigaux (1971) criticaram o modelo do "Constant market-share" devido à desconsideração dos fatores da oferta nas interrelações mundiais de comércio. Ressaltaram, no entanto, da mesma forma que Leamer \& Stern (1970), que o efeito competição, por incorporar os preços, reflete a interação das condições de demanda e oferta.

A vantagem dessa abordagem com relação à análise tradicional da demanda $^{20}$ reside em permitir desagregar os resultados em termos da alocação de esforços para mercadorias e/ou mercados com maior potencial de expansão. Embora a abordagem tenha caráter retrospectivo, é possível utilizá-la para fazer inferências sobre o direcionamento do setor exportador para mercados mais favoráveis, sob a perspectiva da continuidade das tendências observadas nos mercados (Carvalho, 1995).

Algumas ressalvas que podem ser feitas com relação à abordagem relacionam-se aos fatores discutidos a seguir.

(a) A definição de "market-share" em termos de valor exportado implica que um "efeito competitivo", tanto positivo quanto negativo, pode ser consistente com a queda dos preços relativos, dependendo do valor absoluto da elasticidade de substituição. Ou seja,

\footnotetext{
${ }^{19}$ Youtopoulos, P.A. \& Nugent, J. Economics of development: empirical investigations. New York, Harper and Row. 1976. 478p.

${ }^{20}$ É importante observar que essa abordagem metodológica não substitui a tradicional análise de demanda, pois não permite sustentar afirmações probabilísticas sobre os parâmetros calculados (Leamer \& Stern, 1970).
} 
considerando-se que pode ser relacionada a um efeito competitivo positivo, a queda de preços relativos requer a pressuposição adicional de que a elasticidade de substituição seja maior que um em valor absoluto (Carvalho, 1995).

Entretanto, Richardson (1971) discute a possibilidade de que a elasticidade de substituição seja suficientemente grande para que as mudanças nas participações em valor sejam de mesmo sinal das mudanças nas participações em volume, ainda que a magnitude dessas mudanças seja totalmente diferente. Porém, faz-se a ressalva de que como o efeito competitividade depende dessa magnitude, o uso de uma série de dados de valores ao invés de volumes de exportação pode causar um viés na análise do CMS.

(b) Leamer \& Stern (1970) também apontam a possibilidade de ocorrerem distorções relacionadas à interpretação do termo "competitividade", ou seja, quais os fatores compreendidos por esse conceito. Richardson (1971) esclarece que o componente residual - efeito "competitividade", pode refletir, além do preço, a capacidade de venda de um país para mercados estrangeiros em função de qualidade, acordos financeiros, mudanças na política de comércio, padrões de demanda, costumes e preferências, dentre outros já mencionados anteriormente.

Dentre as diversas análises que envolvem o procedimento de CMS destaca-se a de Rigaux (1971), que, de maneira simples e objetiva, utilizou o modelo visando identificar se o efeito competitividade foi o responsável pela redução na participação do trigo canadense no mercado mundial do produto, durante a década de 60 . Para isso, estabeleceu-se a existência dos efeitos "distribuição", "competitividade" e "tamanho de mercado", tendo-se alertado, no entanto, ao fato de que a metodologia não prevê a possibilidade de haver interação entre os efeitos discriminados. Além disso, um efeito competitividade fraco pode ser ocasionado por uma expansão da demanda doméstica, fato esse que não é identificado pela abordagem.

Carvalho et al. (1988) também utilizaram o CMS a fim de verificar se a participação do Brasil no Acordo Internacional do Açúcar - AIA, ao longo do período de 1978-1984, trouxe beneficios no desempenho das exportações comparado ao período anterior ao Acordo (1974-1977). Para tanto, consideraram a existência dos mesmos três efeitos desagregados por Rigaux (1971). No período analisado, os autores obtiveram 
sinal positivo para esses três efeitos, tendo-se verificado que houve predomínio do efeito tamanho de mercado, responsável por $60 \%$ das variações no excedente comercializado pelo País.

Segundo Leamer \& Stern (1970) e Richardson (1971), a análise pode gerar resultados diferentes conforme o período e também o nivel de agregação de mercado escolhidos. Schaub (1987) considera que o uso de períodos que englobam dois ou mais anos nos estudos com CMS pode apresentar resultados mais confiáveis do que quando se trabalha com uma comparação ano a ano. Konandreas \& Hurtado (1978) explicam que essa análise ano a ano tende a evidenciar flutuações decorrentes de fenômenos de curto prazo, muitas vezes conjunturais.

Nas pesquisas sobre a evolução do comércio internacional de um determinado produto exportado por um país e dos fatores que podem ter provocado as modificações, é importante ainda considerar que o quadro de possibilidades desse país no mercado, só fica realmente estabelecido quando as variáveis estudadas são verificadas também para os demais países exportadores (Nonnenberg, 1994).

Savage \& Deutsch (1960) propuseram um modelo probabilistico visando fazer previsões sobre as transações entre países, utilizando dados de suas matrizes de importação e exportação de bens. Contudo, tal modelo não se fundamenta em preceitos teóricos.

Para tanto, esses autores consideraram duas pressuposições básicas:

(a) A primeira delas estabelece que o comércio mundial em determinado ano compreende transações de valores monetários $\mathrm{B}_{1}, \ldots, \mathrm{B}_{\mathrm{N}}$, sendo $\mathrm{N}$ o número de transações efetuadas nesse ano. Considera-se $\mathbf{P}_{\mathrm{ij}}$ como a probabilidade de que o carregamento de um bem (transação) seja transferido do país i para o país $\mathrm{j}$. Tal probabilidade independe do valor da transação e de que um outro carregamento seja efetuado de i' para j'.

(b) A segunda pressuposição trata-se da asserção da independência quanto à origemdestino das exportações, implicando que um carregamento vindo de um determinado país não afeta a probabilidade de ser recebido por outro país, exceção feita para o caso de um país exportar para si mesmo, fato este eliminado por um fator de correção incorporado ao modelo. 
Partindo desse modelo probabilístico, e considerando as mesmas pressuposições básicas apresentadas, Konandreas \& Hurtado (1978) adaptaram o modelo em um trabalho empírico sobre a avaliação do papel dos grandes exportadores de trigo, num contexto de mudanças na estrutura do comércio internacional desse produto.

A adoção desse modelo probabilístico foi justificada por Konandreas \& Hurtado (1978) pelo fato de que, apesar do uso freqüente do modelo de elasticidade de substituição para explicar os fluxos de comércio, suas pressuposições básicas de homogeneidade da commodity e do preço como principal fator determinante das transações, eram limitantes para o caso do trigo, objeto de estudo dos autores. Nesse mercado observou-se que os preços de exportação dos vários ofertantes apresentavam a mesma tendência, de forma que os preços relativos não se alteravam. Desde que os preços relativos não se alteraram, outros fatores foram responsáveis pelas variações nas quantidades comercializadas, sugerindo, portanto, que os importadores não eram indiferentes quanto à origem do trigo. Essa asserção foi confirmada pelos autores, tendose calculado coeficientes de correlação entre os preços anuais dos vários países exportadores.

\subsubsection{Procedimento metodológico}

O mercado mundial de açúcar tem-se tornado cada vez mais competitivo, fato este evidenciado pelas estatísticas mostrando que as exportações e importações mantêm-se aproximadamente no mesmo patamar há anos, e que cada vez mais outros países vêm se tornando auto-suficientes. Diante dessa constatação, considera-se que os produtores e exportadores têm necessidade de um direcionamento quanto aos mercados importadores potenciais e sobre os fatores sobre os quais podem atuar para aumentar sua participação nos mesmos.

A fim de atender ao objetivo de estabelecer qual tem sido o padrão das exportações de açúcar do Brasil para o resto do mundo, ao longo dos últimos 16 anos e, especialmente, se as transformações político-administrativas ocorridas a partir de 1990 desencadearam quaisquer mudanças nesse contexto, pretende-se, utilizando dados das 
exportações brasileiras de açúcar, desagregados por países de destino, apresentar o perfil dos grandes mercados importadores do País. Além disso, o crescimento dessas exportações será analisado de forma a identificar quais os fatores responsáveis pela sua evolução, conforme o subperíodo considerado.

Pretende-se verificar inicialmente se houve um comportamento diferente das exportações dos três principais tipos de açúcar comercializados, quais sejam: cristal, refinado e demerara. Caso a evolução dessas exportações seja semelhante, os dados serão agregados, considerando-se a quantidade total de açúcar exportado para fins da análise de "market-share".

A abordagem adotada está baseada em Leamer \& Stern (1970), Rigaux (1971) e Richardson (1971), tendo sido aplicada por vários autores ao estudo das exportações de commodities. Nesses trabalhos, os produtos são analisados em classes ou individualmente, independente de sua natureza (agropecuária ou manufaturada). Tal abordagem, apesar da simplicidade, é flexível quanto à agregação do período a ser analisado e ao tratamento dos mercados importadores, requerendo um cuidado maior na interpretação dos resultados. No entanto, atende aos objetivos de caracterizar o mercado importador brasileiro de açúcar.

O estudo será conduzido definindo os efeitos de maneira simplificada e considerando-se que os três efeitos analisados podem agir na mesma direção ou compensar-se, parcial ou totalmente. Os efeitos desagregados na análise de "marketshare" são compreendidos segundo os conceitos abaixo discutidos, coincidindo com as definições usadas por Rigaux (1971) e Carvalho et. al. (1988):

(I) O efeito tamanho de mercado mede o impacto da alteração no volume mundial comercializado sobre as exportações de um determinado país, assumindo-se que o país mantenha a sua participação relativa constante no mercado mundial.

(2) O efeito distribuição mede a variação na participação de um país exportador no mercado mundial considerando que a sua participação em cada mercado individual seja mantida constante. Permite avaliar se o Brasil está direcionando seus esforços comerciais para mercados em crescimento e representativos no comércio mundial. 
(3) O efeito competição é de análise mais complexa por agregar variáveis bastante diferentes, sendo identificado diretamente pela mudança no "market-share".

O conceito de competitividade que será adotado é semelhante ao utilizado por Carvalho (1995). Ou seja, considera-se que o "desempenho" está diretamente relacionado à atuação do exportador no mercado internacional, sem indicar os fatores responsáveis pelos resultados.

As taxas de crescimento das exportações mundiais e de alguns países de destaque no mercado de açúcar serão comparadas às taxas de crescimento para o Brasil. A observação das mesmas e dos resultados da análise do modelo de "market-share" constante permitem realizar inferências sobre a existência de outros fatores que podem estar influenciando a evolução desse produto no mercado internacional. Acredita-se que existem países menos comprometidos com o atendimento ao mercado interno e que, portanto, puderam investir mais na produção direcionada à exportação.

A metodologia empregada por Konandreas \& Hurtado (1978) a ser utilizada também no presente trabalho, é descrita a seguir.

Considera-se $x_{i}$ (o "export-share" de um país $i$ ) sendo igual à probabilidade de que um dado bem transacionado tenha origem no exportador $\mathbf{i}$; e $\mathrm{m}_{\mathrm{j}}$ ("import-share" do país $\mathbf{j}$ ) como sendo a probabilidade de que um dado carregamento do bem seja destinado a um país importador $\mathbf{j}$. Disso resulta que a probabilidade de uma mercadoria originar-se no país $\mathbf{i}$ com destino ao país $\mathbf{j}$ é igual a $\left(\mathrm{x}_{\mathbf{i}} \cdot \mathrm{m}_{\mathbf{j}}\right)$, pressupondo a independência da origem-destino.

Tomando-se o fluxo de comércio esperado de $\mathbf{i}$ para $\mathbf{j}$ como:

$$
\hat{X}_{\mathrm{ij}}=\mathrm{xi}_{\mathbf{i}} \mathbf{X}_{00}
$$

em que:

$i=1, \ldots \ldots . . N$ países exportadores;

$\mathrm{j}=1, \ldots, \mathrm{n}$ paises importadores; $\mathrm{e}$

$\mathrm{X}_{\mathrm{ij}}=$ volume total do bem comercializado em um determinado ano. 
Adotando-se $\mathrm{X}_{\mathrm{ij}}$ e $\hat{X}_{\mathrm{ij}}$ como quantidade exportada efetiva e quantidade exportada esperada, respectivamente, essas considerações sobre preferências podem ser sumarizadas por uma medida chamada "aceitação relativa" ou "grau de preferência" entre dois países, definida como:

$$
P_{i j}=\frac{X_{i j}}{\hat{X}_{i i}}
$$

Konandreas \& Hurtado (1978) definem essa variável como "grau de preferência" de forma que se assumir valor maior que a unidade, identifica-se a existência de uma preferência "extra-preço" pelo produto do país analisado, o que está relacionado a fatores de política comercial tais como: restrições quantitativas, tarifas de importação, subsídios à exportação e política de câmbio, favoráveis ao comércio entre os paises i e j.

Savage \& Deutsch (1960) denominaram a "aceitação relativa" como:

$$
R A_{i j}=\frac{X_{i j}-\hat{X}_{i j}}{\hat{X}_{i j}}
$$

Quando o valor da relação indicada pela eq. (12) é alto, independentemente do seu sinal, tem-se uma indicação de que existem fatores importantes além dos fatores relacionados ao "market-share" que podem estar determinando as quantidades comercializadas. As equações (11) e (12) representam a mesma medida, estando relacionadas pela seguinte igualdade:

$$
\mathrm{RA}_{\mathrm{ij}}=\mathbf{P}_{\mathrm{ij}}-1
$$

Substituindo a eq. (11) na (10), diferenciando-se com relação ao tempo e somando-se para todos os importadores, obtém-se o crescimento total das exportações de um país, representado por $\stackrel{0}{X}$, que pode ser desagregado nos seguintes efeitos:

$$
\stackrel{0}{X}_{j}=\sum_{j} \stackrel{0}{X}_{i j} \quad \text { (crescimento total das exportações totais) }
$$


$=x_{i} \stackrel{0}{00}_{0} \sum_{j} P_{i j} m_{j}+\quad$ (efeito crescimento do mercado mundial)

${ }_{x_{i}} X_{00} \sum_{j} P_{i j} m_{j}+\quad$ (efeito competitividade do pais )

$\mathrm{xi} X 00 \sum_{j} P_{i j .} \stackrel{0}{m}_{j}+\quad$ (efeito mercado importador)

$x_{i} X_{00} \sum_{j} \stackrel{0}{P}_{i j} m_{j} \quad$ (efeito estrutura de preferências)

Os efeitos "crescimento do mercado mundial", "competitividade" e "mercado importador" têm basicamente os mesmos significados já discutidos quando os modelos CMS foram apresentados. O efeito "estrutura de preferências" distingue o modelo de Konandreas \& Hurtado (1978) dos anteriores, tratando-se de um componente que depende das variações no nível de preferência dos países importadores em relação ao produto do país exportador.

Os efeitos "mercado importador" e "estrutura de preferências" diferem entre si pelo fato de que o primeiro será positivo se o país incrementar suas transações com mercados importadores em expansão e o efeito estrutura de preferências será positivo, especificamente, se o país adotar acordos de preferências com grandes importadores.

Neste trabalho, devido à dificuldade em obter dados da matriz de exportação dos demais países exportadores, para aplicar o modelo usado por Konandreas \& Hurtado (1978) procedeu-se à agregação dos países importadores em: ex-União Soviética, China e Japão e Resto do Mundo. Os países exportadores consistem de Brasil, Cuba e Resto do Mundo ${ }^{21}$.

\footnotetext{
${ }^{21}$ A respeito da seleção de países ou grupo de países para realizar a análise de "market-share", Rigaux (1971) comenta que o mercado pode ser distinto em vários niveis. desde grupos de países até regiões de um pais. No seu trabalho empirico, justifica a escolha de alguns países tomados isoladamente por serem países cujo mercado que se destaca pela importância e dimensão e com características distintas, de forma a não comportar seu agrupamento com outros paises. Além disso. há nações tratadas como uma unidade por razões de integração econômica, assim como há paises com mercados pequenos demais para serem tratados isoladamente.
} 
Outro indicador utilizado por Konandreas \& Hurtado (1978), e que será calculado no presente trabalho para avaliar o padrão das exportações e sua evolução, é o Índice de Concentração Geográfica das exportações e o Índice de Concentração Geográfica das importações. Esses índices mostram, respectivamente, o grau de diversificação do destino das exportações e o grau de diversificação da origem das importações para um determinado país. O Índice de Concentração Geográfica das exportações é calculado especificamente para cada ponto no tempo, através da expressão abaixo ${ }^{22}$ :

$$
\sqrt{\sum_{j=1}^{n}\left(m_{i j}\right)^{2}}
$$

$\mathrm{O}$ termo $\mathrm{m}_{\mathrm{ij}}$ (dentro do parênteses) representa a importação pelo país $\mathbf{j}$ do produto originado do pais i expresso como uma percentagem do total de exportações do i-ésimo país exportador. Quanto mais próximo de 100 , mais concentrada é a exportação desse país com relação aos destinatários do bem comercializado (Konandreas \& Hurtado, 1978).

O uso de períodos com mais de um ano também já foi justificado pelo fato de que não se pretende identificar fatores relevantes de curto prazo, mas sim fatores estruturais que influenciam tendências de médio e longo prazo. Desde que a literatura não estabelece regras rigidas relacionadas à seleção dos períodos, procedeu-se à divisão em três subperíodos: 1979/84, 1985/89 e 1990/94. Para tanto, o critério baseou-se na agregação de anos com tendências semelhantes quanto à evolução do volume exportado, assunto que já foi tratado no capítulo anterior.

\footnotetext{
${ }^{22}$ Esses indices foram originalmente definidos por Michaely (1962), citado por Konandreas \& Hurtado (1978). De forma análoga ao Índice de Concentração Geográfica das exportações, o Índice de Concentração Geográfica das importações é dado pela expressão:
}

$$
\sqrt{\sum_{i=1}^{N}\left(x_{i j}\right)^{2}}
$$




\subsection{O modelo de Elasticidade de Substituição ${ }^{23}$}

Os estudos sobre a elasticidade de substituição, no âmbito do comércio internacional, desenvolveram-se bastante em função da busca de alternativas para obter valores de elasticidades-preço de demanda que se aproximassem mais da realidade observada pelos pesquisadores. Johnson et al. (1979) comentam que a maioria dos trabalhos estimando elasticidade de substituição tinha como meta verificar se a mesma podia ser usada como uma forma indireta de estimar a elasticidade preço da demanda de exportações dos países ${ }^{24}$.

Recentemente, o destaque dado à avaliação da elasticidade de substituição nos estudos de comércio internacional deve-se a sua utilidade na análise sobre a competitividade dos produtos agrícolas exportados por dois países com destino a um terceiro mercado (importador). No presente trabalho, esse aspecto é abordado para o caso específico do mercado de açúcar.

As hipóteses formuladas sobre a elasticidade de substituição são importantes quando o objetivo é concluir sobre a sua influência nas vendas de exportação. Isto torna-se mais evidente em casos onde é necessário explicar os modelos de comércio existentes para determinados países exportadores, vis-à-vis um outro país. Esse conhecimento pode ser útil em termos de estabelecimento de políticas de preços de exportação pela indústria (setor privado) e para formular políticas governamentais (Leamer \& Stern, 1970).

A elasticidade de substituição é definida teoricamente com relação a uma única curva de indiferença, podendo ser representada pela seguinte relação:

$$
\varepsilon=\frac{\partial\left(q_{1} / q_{2}\right)}{\partial\left(\partial q_{2} / \partial q_{1}\right)} \times \frac{\partial q_{2} / \partial q_{1}}{q_{1} / q_{2}}=\frac{\partial \log \left(q_{1} / q_{2}\right)}{\partial \log \left(\partial q_{2} / \partial q_{1}\right)}
$$

\footnotetext{
${ }^{23}$ A apresentação do modelo de elasticidade de substituição está baseada em Leamer \& Stern (1970).

${ }^{24}$ Segundo Leamer \& Stern (1970) a estimação da elasticidade de substituição em detrimento às funções de demanda convencionais evita problemas de colinearidade entre as variáveis preço e renda, melhora a significância estatística e exige um menor número de variáveis.
} 
Na eq. (20) a elasticidade de substituição ( $(\varepsilon)$ entre os produtos ofertados pelos países 1 e 2, em relação a um mercado importador comum, é medida pela taxa de variação percentual nas quantidades relativas $\left(\mathrm{q}_{1} / \mathrm{q}_{2}\right)$ em razão da variação percentual na taxa marginal de substituição de $\mathrm{q}_{2}$ por $\mathrm{q}_{1}$. Considerando-se a maximização da utilidade com restrição orçamentária, obtém-se como resultado de primeira ordem:

$$
\frac{\partial q_{2}}{\partial q_{1}}=\frac{p_{1}}{p_{2}}
$$

Substituindo (21) na eq. (20), tem-se a seguinte definição empírica da elasticidade de substituição, empregada por Medeiros \& Teixeira (1994) e Fontes et al. (1989):

$$
\varepsilon=\frac{\partial\left(\frac{q_{1}}{q_{2}}\right)}{\left(\frac{q_{1}}{q_{2}}\right)} \div \frac{\partial\left(\frac{p_{1}}{p_{2}}\right)}{\left(\frac{p_{1}}{p_{2}}\right)}=\frac{\partial \log \left(\frac{q_{1}}{q_{2}}\right)}{\partial \log \left(\frac{p_{1}}{p_{2}}\right)}
$$

$\mathrm{Na}$ expressão (22) a elasticidade de substituição pode ser entendida como a variação percentual nas quantidades relativas demandadas de dois bens $\left(q_{1}\right.$ e $\left.q_{2}\right)$ dividida pela variação percentual nos seus preços relativos. Seu valor vai depender da curva de indiferença selecionada e da relação de preços $\left(\mathrm{p}_{1} / \mathrm{p}_{2}\right)$.

Quando essa elasticidade (de sinal negativo) for maior do que a unidade em valores absolutos, os bens produzidos pelos paises são considerados substitutos próximos pelo mercado, caracterizando a existência de uma forte competição entre esses exportadores. Se o valor da elasticidade de substituição é baixo, tem-se uma indicação de que não há um grau elevado de substitutibilidade entre os bens 1 e 2 , portanto, a competição entre eles é pequena. Nesse segundo caso, os produtos provavelmente são diferenciados pelo país de origem, preferências, acordos institucionais, dentre outros fatores (Leamer \& Stern, 1970).

A definição teórica com relação a uma única curva de indiferença gera problemas na estimação da elasticidade em trabalhos empíricos. Leamer \& Stern (1970) 
comentam que as condições necessárias para que a elasticidade de substituição esteja relacionada apenas com a razão dos preços, é que a inclinação da curva de indiferença deve depender somente de $\left(\mathrm{q}_{1} / \mathrm{q}_{2}\right)$, sendo indiferente a qualquer fator de escala. Isso significa que as elasticidades-renda dos bens 1 e 2 são iguais, situação que, segundo Morrissett (1953), é observada para funções lineares homogêneas e suas transformações monotônicas.

A aplicação prática deste modelo de elasticidade de substituição nos estudos de comércio internacional tem sido comumente realizada adotando-se uma forma logarítmica, derivada da equação (22). Assim, o coeficiente b estimado consiste na elasticidade de substituição, sendo um valor constante:

$$
\log \left(\frac{q_{1}}{q_{2}}\right)=a+b \log \left(\frac{p_{1}}{p_{2}}\right)
$$

Para que a eq. (23) apresente resultados consistentes, as seguintes pressuposições simplificadoras devem-se verificar ${ }^{25}$, segundo Leamer \& Stern (1970):

(i) que a soma algébrica das elasticidades-direta e cruzada da demanda seja igual para os dois bens $q_{1}$ e $q_{2}\left(e_{11}+e_{12}=e_{22}+e_{21}\right)$;

(ii) que as elasticidades-preço assim como as elasticidades-renda da demanda para os dois bens também sejam iguais.

Nesse sentido, é razoável considerar que os bens com tais características são bastante semelhantes embora não sejam substitutos perfeitos, de forma que exista demanda para ambos no mercado importador. Além disso, supõe-se que a oferta de importação é perfeitamente elástica, isto é, os países importadores são muito pequenos em relação aos países exportadores e, consequentemente, os preços são pré-determinados ou exógenos ao modelo.

Morrisset (1953) realizou um estudo crítico sobre esse conceito de elasticidade de substituição, analisando suas interpretações e examinando sua aplicação

\footnotetext{
${ }^{25}$ No caso das condições de simetria não se verificarem, as estimativas obtidas podem desvincular-se do conceito teórico da elasticidade de substituição resultando até mesmo em coeficientes $b>0$, mostrando complementaridade ao invés de substitubilidade.
} 
para estimar a demanda de produtos relacionados, tendo concluído que o conceito de elasticidade de substituição refere-se exclusivamente a movimentos ao longo de uma curva de indiferença específica. Essa elasticidade pode ser considerada única quando se refere a uma única curva de indiferença (duas mercadorias, e um único consumidor), sendo que o conceito de curva de indiferença comunitária pode apresentar algumas restrições.

Portanto, segundo Leamer \& Stern (1970), é razoável adotar a eq. (23) quando é possível pressupor que o país tem um mapa de curvas de indiferença bem comportado. Devido a esses problemas conceituais, desenvolveu-se uma análise equivalente, porém fundamentada nos conceitos da demanda convencional ${ }^{26}$ de exportações, a qual considera a eq. (24) como uma alternativa preferivel para proceder a análises empíricas empregando esse conceito. A eq. (24) expressa, segundo Leamer \&

${ }^{26}$ Tomando-se as seguintes funções de demanda para o bem $\mathrm{q}_{1}$ e o bem $\mathrm{q}_{2}$ :

$$
\mathrm{q}_{1}=\mathrm{f}\left(\mathrm{p}_{1}, \mathrm{p}_{2}, \mathrm{y}, \mathrm{p}_{\mathrm{n}}\right) \text { e } \mathrm{q}_{2}=\mathrm{g}\left(\mathrm{p}_{1}, \mathrm{p}_{2}, \mathrm{y}, \mathrm{p}_{\mathrm{n}}\right)
$$

onde y é a renda monetária do país importador e $p_{n}$ é o nível geral de preços incluindo preços de outros bens importados que competem nesse mercado. Assumindo então funções que geram elasticidades constantes:

$$
\begin{aligned}
& q_{1}=a \cdot p_{1}^{\alpha 1} p_{2}^{\alpha 2} y^{\alpha y} p_{n}^{\alpha n} \\
& q_{2}=b \cdot p_{1}^{\beta 1} p_{2}^{\beta 2} y^{\beta y} p_{n}^{\beta n}
\end{aligned}
$$

onde os $\alpha$ 's e os $\beta$ 's são as elasticidades das respectivas variáveis. Dividindo-se (2.1) por (2.2), tem-se:

$$
\frac{q_{1}}{q_{2}}=\frac{a}{b} * \frac{p^{\alpha 1-\beta 1}}{p^{\beta 2-\alpha 2}} * y^{\alpha y-\beta y} * p_{n}^{\alpha n-\beta n}
$$

A equação (3) evidencia que $q_{1} / q_{2}$ pode ser relacionado somente com o termo $\left(p_{1} / p_{2}\right)$ se os expoentes de $p_{1}$ e de $p_{2}$ forem iguais: $\alpha_{1}-\beta_{1}=\beta_{2}-\alpha_{2}$ e se os expoentes do termo renda monetária e do termo "preços dos outros bens" forem nulos. Conclui-se disto que, a soma das elasticidades cruzadas e diretas da demanda serão iguais para todos os bens $\left(\alpha_{1}+\alpha_{2}=\beta_{1}+\beta_{2}\right)$, e que a elasticidade-renda do bem 1 e a sua elasticidade preço cruzada com terceiros bens, são iguais às do bem $2\left(\alpha_{y}=\beta_{y} ; \alpha_{n}=\beta_{n}\right)$, ou seja, $\mathrm{q}_{1}$ e $\mathrm{q}_{2}$ são muito semelhantes, sendo suficientemente distintos apenas para caracterizarem dois bens diferentes. Esses resultados foram os mesmos verificados na análise através da teoria da utilidade (Leamer \& Stern, 1970).

Se a função for estimada relacionando a razão das quantidades em relação à razão dos preços, sem que as condições de igualdade dos coeficientes de $p_{1}$ e $p_{2}$ se verifiquem, o conceito de elasticidade de substituição torna-se degenerado pois a sua estimativa dependerá da evolução individual de cada preço, significando que haverá uma estimativa para cada periodo diferente, caso os preços de 1 e de 2 não apresentem as mesmas trajetórias. 
Stern (1970), a elasticidade de substituição de forma mais completa, pois incorpora outros fatores que podem influenciar os resultados.

$$
\log \left(\frac{q_{1}}{q_{2}}\right)=a+b_{1} \log p_{1}+b_{2} \log p_{2}+c \log y+d \log p_{n}
$$

$\mathrm{Na}$ equação acima, $\mathbf{y}$ representa a renda monetária e $\mathbf{p}_{\mathrm{n}}$ é o nível geral de preços dos demais bens além de 1 e 2 , incluindo os produtos substitutos importados por um determinado país. Geralmente, os coeficientes c e d são valores pequenos, o que indica que a relação entre as quantidades exportadas depende mais diretamente dos preços dos bens analisados, para um determinado par de países. Quando se exclui as variáveis $\mathbf{y}$ e $\mathbf{p}_{\mathbf{n}}$, a estimativa da elasticidade de substituição pode tornar-se estatisticamente viesada, caso essas duas variáveis estejam correlacionadas à relação dos preços $\left(\mathrm{p}_{1} / \mathrm{p}_{2}\right)$. As seguintes hipóteses devem ser testadas para que a relação $\left(\mathrm{q}_{1} / \mathrm{q}_{2}\right)$ seja dependente apenas de $\left(\mathrm{p}_{1} / \mathrm{p}_{2}\right)$ :

$$
\begin{aligned}
& b_{1}=-b_{2} \\
& c=d=0
\end{aligned}
$$

A verificação das condições (I) e (II) pela abordagem da teoria da demanda são equivalentes às condições (i) e (ii) pressupostas na análise do ponto de vista da teoria da utilidade. Na realidade, significam que para que as estimativas resultantes de (23) e de (24) sejam consistentes com a teoria, os bens 1 e 2 devem ser muito semelhantes, de forma que as respostas das suas respectivas demandas sejam as mesmas, dadas as variações nos seus preços, nos preços de outros produtos e na renda.

No modelo de elasticidade de substituição apresentado por Leamer \& Stern (1970), são necessários apenas dados de séries temporais de quantidade e preços relativos para proceder à estimação. Alternativamente, Ginsburg ${ }^{27}$, cujo trabalho é discutido por esses mesmos autores, baseou-se no pooling de séries temporais e dados de cortes-seccionais (cross-section), possibilitando enriquecer a análise e dar maior

\footnotetext{
${ }^{27}$ Ginsburg, A.L. American and British regional export determinants. Amsterdam: North-Holland Publ. 1969.
} 
relevância às variáveis qualitativas. Argumenta-se ainda, que os resultados empíricos podem melhorar com procedimentos de desagregação das proporções de quantidades e preços de acordo com as regiões importadoras, e pela segmentação da relação de preço em intervalos, permitindo relações curvilíneas.

Silva (1992) estimou a elasticidade de substituição do suco de laranja no mercado internacional utilizando o modelo de cortes seccionais (cross-section) e séries temporais. Além disso, utilizou uma metodologia que permitiu verificar a validade das pressuposições do modelo de elasticidade de substituição para o caso específico do suco de laranja.

Destacam-se outros trabalhos empíricos que utilizaram o modelo de elasticidade de substituição para produtos de origem agrícola. Fontes et al. (1989) empregaram o método dos mínimos quadrados ordinários, mínimo quadrado em dois estágios e em três estágios para estimar a elasticidade de substituição de trigo e milho dos Estados Unidos, usando dados trimestrais. Observaram variações significativas nos valores encontrados para diferentes paises importadores, relacionando a origem dos produtos com o seu grau de diferenciação por esses importadores. Segundo os autores, a elasticidade de substituição não está diretamente relacionada à questão da diferenciação. No entanto, comentam que um valor baixo dessa elasticidade indica que o bem exportado não é considerado como substituto entre os paises, ou seja, sugerindo que o produto é diferenciado conforme seu pais de origem.

Nesse mesmo trabalho, uma análise adicional foi proposta por Fontes et al. (1989) incorporando variáveis defasadas ao modelo a fim de determinar o papel da rigidez de mercado, e admitindo que esse é um fator geralmente decisivo para a definição das importações realizadas por um país. Essa defasagem foi acrescentada ao modelo através da razão das quantidades comercializadas pelos dois países competidores, defasadas em um período, e verificando-se a significância de seu coeficiente. Essa abordagem será testada no presente trabalho para o caso do açúcar, e seus resultados serão comparados com aqueles obtidos na estimação da eq. (23).

Fontes et al. (1989) compararam as estimativas de elasticidade de substituição obtidas por equações simples, com aquelas estimadas através de sistemas de 
equações, sendo que essa segunda opção considera a possibilidade de correlação entre resíduos das equações de demanda dos países importadores. As conclusões obtidas nos dois casos foram as mesmas em termos da classificação dos países importadores conforme sua resposta aos preços.

Outra análise realizada por Fontes et al. (1989) foi a comparação do método tradicional com o das variáveis instrumentais e mínimo quadrado em três estágios, sendo que nos dois últimos casos a oferta de importação deixou de ser considerada elástica (os preços de importação passam a ser variáveis endógenas do modelo), significando que o país tem influência sobre a formação desses preços no mercado internacional. A pressuposição convencionalmente adotada por vários estudiosos de que o preço de importação é uma variável exógena torna-se bastante restritiva à medida que um importador pode ser suficientemente relevante, de tal forma que variações na sua quantidade demandada interfiram na formação dos preços internacionais.

O crescimento observado nas exportações de açúcar do Brasil, nos últimos cinco anos, torna questionável a possibilidade de considerar seus preços de exportação como uma variável endógena no presente trabalho. No entanto, essa possibilidade não será testada empiricamente através do modelo de elasticidade de substituição, devido ao número limitado de observações disponíveis para proceder a uma estimação econométrica confiável ou a qualquer previsão de evolução futura.

Outra análise possível através dos resultados do modelo de elasticidade de substituição é a avaliação dos efeitos de integrações econômicas sobre a competitividade de exportações. Essa abordagem foi utilizada no trabalho realizado por Fontes \& Barbosa $^{28}$, citados por Vasconcelos (1994), para o caso da soja brasileira. Verificou-se que tais efeitos variaram em função do bloco econômico e dos produtos considerados; e além disso, que as elasticidades obtidas com a integração mostraram-se inferiores àquelas obtidas na ausência da mesma.

${ }^{28}$ Fontes, R. M. O. ; Barbosa, M.L. Efeitos da integração econômica na competitividade das exportações brasileiras de soja. 1990, 18p. (mimeo) 
Vasconcelos (1994) estudando o caso da soja brasileira e de seus produtos, também usou o modelo de elasticidade de substituição, obtendo estimativas através de mínimos quadrados ordinários. A variabilidade das elasticidades foi analisada pela autora conforme produtos e local de destino, e quanto à agregação dos países, tendo discutido os resultados em termos de implicações das novas relações no comércio internacional sobre a competitividade no mercado da soja.

\subsubsection{Procedimento metodológico}

A abordagem da elasticidade de substituição foi aplicada no presente trabalho com o objetivo de avaliar a competitividade do açúcar brasileiro em relação aos principais países ofertantes neste mercado, e procurando-se verificar se nos últimos cinco anos ocorreram mudanças significativas no padrão de competitividade do País nesse mercado. Os resultados podem evidenciar quais são e como evoluem os principais concorrentes do Brasil no mercado exportador açucareiro, ao longo do período analisado, compreendendo os anos de 1979 a 1994.

As elasticidades de substituição serão estimadas para o Brasil em relação aos principais paises exportadores deste produto no mercado mundial, quanto às quantidades exportadas para um terceiro mercado, o Resto do Mundo. Não foi possível obter dados desagregados por país exportador e os respectivos países de destino de suas exportações de açúcar, como já foi mencionado.

Os exportadores de açúcar considerados compreendem: Austrália, Cuba, França, Tailândia, África do Sul, República Dominicana, Filipinas e Alemanha. O critério dessa seleção foi escolher os paises cujas médias anuais de exportação nos últimos 16 anos foram as maiores entre os exportadores mundiais. As elasticidades serão estimadas para o açúcar total, açúcar bruto (demerara + cristal) e açúcar refinado, separadamente, conforme permite a desagregação das informações compiladas da FAO Trade Yearbook.

Para obter as estimativas das elasticidades de substituição será empregado o método dos mínimos quadrados ordinários (MQO). A existência de correlação nos resíduos será verificada através do teste de Durbin-Watson e, se confirmada, será 
utilizado o procedimento proposto pelo método de Cochrane-Orcutt para a obtenção de séries ruídos brancos (Johnston, 1984). As regressões serão processadas utilizando o software Regression Analysis of Time Series - RATS (Doan, 1993) e a significância estatística dos coeficientes estimados será avaliada pelo teste “" " de Student.

A equação de estimação a ser utilizada neste modelo deriva da eq. (23), assumindo-se que as condições (i) e (ii), mencionadas no sub-ítem anterior (página 55), são atendidas:

$$
\log \left(\mathrm{q}_{1} / \mathrm{q}_{\mathrm{i}}\right)_{\mathrm{t}}=\alpha+\beta \log \left(\mathrm{p}_{1} / \mathrm{p}_{\mathrm{i}}\right)_{\mathrm{t}}+\mathrm{u}_{\mathrm{t}}
$$

em que:

$\mathrm{i}=1, \ldots \ldots . . .8$, é o índice referente ao país exportador de açúcar;

$\mathrm{t}=1, \ldots \ldots .16$, é o periodo, em anos;

$\mathrm{q}_{1}=$ quantidade anual de açúcar exportada pelo Brasil para o resto do mundo, em toneladas;

$\mathrm{q}_{\mathrm{i}}=$ quantidade anual de açúcar exportada pelo país i, em toneladas;

$\alpha=$ termo constante da regressão;

$\beta=$ coeficiente da regressão, correspondendo à elasticidade de substituição entre o Brasil e o pais $\mathbf{i}$;

$\mathrm{p}_{1}=$ preço médio anual das exportações de açúcar do Brasil para o Resto do mundo, em dólares por tonelada;

$\mathrm{p}_{\mathrm{i}}=$ preço médio anual das exportações do país i para o Resto do mundo, em dólar por tonelada; $\mathrm{u}_{\mathrm{t}}=$ erro aleatório, com distribuição normal, média zero e variância constante.

A pressuposição adicional adotada neste procedimento é a caracterização do Brasil como um país "pequeno" no comércio internacional, de forma que os preços de exportação são pré-determinados no modelo.

Além das regressões resultantes de (25), que serão estimadas visando obter as elasticidades de substituição entre o Brasil e cada um dos oito grandes exportadores em relação ao Resto do Mundo, a eq. (26) vai ser utilizada, incorporando uma variável defasada da razão entre as quantidades exportadas de açúcar pelo par de 
países ofertantes. A aplicação de tal procedimento tem a finalidade de verificar se o coeficiente desse termo apresenta-se significativo, o que, segundo Fontes et al. (1989), sugere a existência de "rigidez do mercado", decorrente da intervenção governamental no setor. A equação de regressão fica sendo nesse caso:

$$
\log \left(\mathrm{q}_{1} / \mathrm{q}_{\mathrm{i}}\right)_{t}=\alpha+\beta \log \left(\mathrm{p}_{1} / \mathrm{p}_{\mathrm{i}}\right)_{\mathrm{t}}+\gamma \log \left(\mathrm{q}_{1} / \mathrm{q}_{\mathrm{i}}\right)_{\mathrm{t}-1}+\mathrm{u}_{\mathrm{t}}
$$

As mesmas observações e hipóteses formuladas para a eq. (25), são válidas para a eq. (26), a qual será estimada também pelo método de mínimos quadrados ordinários, obtendo-se além dos coeficientes já relacionados, o coeficiente da variável defasada $(\gamma)$. Neste caso, o teste Q de Ljung-Box (Doan, 1993) será utilizado para detectar a autocorrelação de resíduos ao invés do teste de Durbin-Watson, já que esse último não é considerado apropriado quando se utilizam modelos contendo defasagens da variável endógena no papel de variável independente (Johnston, 1984; Hoffmann \& Vieira, 1987).

\subsection{Dados}

Os dados de quantidades de açúcar comercializadas mundialmente e por países e os dados referentes ao valor dessas transações, utilizados no trabalho empírico de estimação das elasticidades de substituição e na análise de "market-share", foram obtidos das publicações da FAO - FAO Trade Yearbook, para o período entre 1979 e 1994. Os dados de preços dessas exportações e importações foram calculados como uma "proxy", dividindo-se esses valores pelas quantidades transacionadas. As taxas de crescimento das exportações e os coeficientes de correlação necessários também foram estimados com base nesses dados.

Os volumes e valores das exportações de açúcar do Brasil, por país de destino e por tipo de açúcar, foram compilados das publicações da CARTEIRA DE COMÉRCIO (CACEX)/Banco do Brasil para o periodo entre 1979 e 1988. Para o restante do periodo, 1989 a 1995, os dados foram obtidos diretamente com a Secretaria de Comércio Exterior (SECEX), no Rio de Janeiro. 
As quantidades e os preços de exportação de Cuba conforme seus principais mercados importadores são da International Sugar Organization (ISO) e foram obtidos através de buscas na Internet. 


\section{RESULTADOS E DISCUSSÃO}

\subsection{Modelos de "market-share"}

A escolha dos dois modelos propostos no capítulo da metodologia, o de "market-share" e o da elasticidade de substituição, teve como finalidade agregar resultados que contêm informações complementares. A análise de "market-share" dá ênfase ao desempenho de cada país exportador em relação ao seu mercado importador, enquanto que os resultados obtidos numa análise de elasticidade de substituição permitem inferir sobre o relacionamento desse exportador com os demais concorrentes do mercado estudado.

Os resultados da análise de "market-share" foram obtidos utilizando-se dois procedimentos, sendo o primeiro baseado no trabalho de Rigaux (1971), que explora a evolução das exportações brasileiras de açúcar enfatizando o comportamento em cada mercado importador relevante, de forma individual. A segunda análise foi elaborada com base na abordagem de Konandreas \& Hurtado (1978), cuja diferença básica é a inclusão do efeito "estrutura de preferências".

\subsubsection{Análise de "market-share" - O crescimento das exportações e o mercado importador brasileiro}

Para proceder à análise semelhante à de Rigaux (1971), foram utilizados valores médios de volumes de exportação agregados para aqueles subperiodos já apresentados no sub-ítem 2.2 do segundo capítulo.

A análise expõe os resultados de forma que permite, primeiramente, verificar a atuação do Brasil nos mercados importadores selecionados, discriminando a participação das exportações brasileiras em cada um deles. Em segundo lugar, permite desagregar as diferenças entre as quantidades efetivamente transacionadas e aquelas 
esperadas (que indicam o crescimento positivo ou negativo das exportações) em termos dos efeitos "tamanho de mercado", "distribuição" e "competitividade".

A Tabela 8 mostra os resultados dessa análise para o primeiro intervalo. Durante o subperíodo de 1979 a 1984, os EUA e a ex-URSS foram os dois maiores importadores brasileiros de açúcar em termos de volume comercializado. Os paises da África, destacando-se o Egito e a Argélia, também importaram grandes quantidades sendo que o produto originado do Brasil representou, em média, $30 \%$ das importações totais de cada um desses países nesse subperíodo. Segundo os dados da tabela, grande parte do açúcar importado pela Venezuela e pelo Iraque também foi originado do Brasil. Destaca-se a concentração das exportações brasileiras que, em grande parte, foram destinadas a esses seis primeiros países discriminados na Tabela 8 e mencionados acima, entre os anos de 1979 e 1984.

Comparando o subperíodo 1979/84 com 1985/89, observa-se que a participação média do Brasil no total mundial comercializado caiu de $9,14 \%$ para $7,14 \%$, sendo que todos os países identificados como importantes parceiros no primeiro subperiodo tiveram sua parcela bastante reduzida na pauta das exportações brasileiras. Essa tendência acompanhou a retração do comércio mundial de açúcar observada em meados da década de 80 .

Verifica-se, entretanto, um aumento da participação do Brasil nas importações de açúcar realizadas pela África, América Central e do Norte. Ainda nesse periodo o Brasil passa a participar das importações da Oceania, embora apenas marginalmente.

A Tabela 9 mostra os componentes da redução verificada entre os subperiodos 1979/1984 e 1985/89. Tem-se indicação de que os três efeitos analisados, "tamanho", "distribuição" e "competitividade", atuaram conjuntamente no sentido de promover a redução nas exportações brasileiras de açúcar. Dessa redução total na participação, $51,85 \%$ foi relacionada ao efeito distribuição, significando que o Brasil concentrou esforços de comercialização com países cujos mercados importadores se retrairam. 
Tabela 8 - Exportação média anual brasileira e mundial de açúcar nos subperiodos 1979/84 e 1985/89 em toneladas; e participação do Brasil nas quantidades importadas de açúcar pelos seus principais importadores e por continentes

\begin{tabular}{|c|c|c|c|c|c|c|c|c|}
\hline & \multicolumn{3}{|c|}{ 1979/1984 } & \multicolumn{3}{|c|}{$1985 / 89$} & \multicolumn{2}{|c|}{ Brasil $1985 / 89$ na $\%$ de $79 / 84$} \\
\hline \multirow[t]{2}{*}{ Mercado } & $\begin{array}{l}\text { Importação } \\
\text { Mundial ** }\end{array}$ & $\begin{array}{c}\text { Exportação } \\
\text { Brasil }{ }^{\star \star \star}\end{array}$ & $\begin{array}{c}\text { Participação } \\
\text { Brasil (\%) }\end{array}$ & $\begin{array}{l}\text { Importação } \\
\text { Mundial ** }\end{array}$ & $\begin{array}{c}\text { Exportação } \\
\text { Brasil }\end{array}$ & $\begin{array}{c}\text { Participação } \\
\text { Brasil (\%) }\end{array}$ & $(3) \times(4)$ & $(5)-(7)$ \\
\hline & $(1)$ & (2) & (3) & (4) & (5) & (6) & (7) & (8) \\
\hline EUA & $3.518 .272,8$ & $610.666,0$ & 17,36 & $1.766 .444,0$ & $144.913,5$ & 8,20 & $306.601,4$ & $-161.687,92$ \\
\hline Ex-URSS & 5.573 .9 & $546.635,0$ & 9,81 & $4.887 .576,0$ & $365.546,7$ & 7,48 & $479.324,9$ & $-113.778,28$ \\
\hline Egito & 14,0 & $196.120,0$ & 30,64 & 316,0 & $130.481,3$ & 19,48 & $205.252,3$ & 0,91 \\
\hline Argélia & $594.954,2$ & $187.180,0$ & 31,46 & $781.970,0$ & $107.041,8$ & 13,69 & $246.017,5$ & -138.97 \\
\hline Venezuela & $376.876,2$ & $166.884,0$ & 44,28 & $182.138,0$ & $26.230,0$ & 14,40 & $80.652,3$ & $-54.422,27$ \\
\hline Iraque & $552.409,3$ & $121.845,0$ & 22,06 & $574.892,0$ & $120.263,6$ & 20,92 & $126.804,0$ & $-6.540,43$ \\
\hline África ${ }^{\star}$ & $2.097 .030,8$ & $169.016,5$ & 8,06 & $1.922 .316,0$ & $237.523,1$ & 12,36 & $154.934,8$ & $82.588,26$ \\
\hline Am. Cent. e Norte & $1.531 .583,5$ & $56.089,1$ & 3,66 & $1.242 .676,0$ & $144.913,5$ & 11,66 & $45.508,8$ & $99.404,68$ \\
\hline América do Sul* & $357.253,2$ & $45.117,7$ & 12,63 & $259.332,0$ & $53.463,6$ & 20,62 & $32.751,2$ & $20.712,45$ \\
\hline Ásia* & $8.292 .360,2$ & $372.731,3$ & 4,49 & $10.131 .726,0$ & $584.812,8$ & 5,77 & $455.408,5$ & $129.404,34$ \\
\hline Europa & $4.295 .306,7$ & $90.194,1$ & 2,10 & $5.182 .622,0$ & $76.730,2$ & 1,48 & $108.826,2$ & $-32.096,06$ \\
\hline Oceania & $203.589,3$ & - & 0,00 & $206.984,0$ & $3.800,0$ & 1,84 & - & $3.800,00$ \\
\hline TOTAL & $28.033 .406,0$ & $2.562 .479,0$ & 9,14 & $27.808 .476,0$ & $1.984 .166,6$ & 7,14 & $2.541 .918,6$ & $-557.751,99$ \\
\hline \multicolumn{4}{|l|}{ Soma da coluna (7) } & & & & $2.242 .081,9$ & \\
\hline
\end{tabular}

* Os valores totais do grupo foram subtraídos das quantidades já consideradas dos 6 países acima.

Fonte: Elaborado a partir de dados da ${ }^{* \star}$ FAO Trade Yearbook; ${ }^{\star \star \star}$ CACEX/SECEX. 
Tabela 9 - Componentes do ganho/perda nas exportações brasileiras de açúcar. $1979 / 84$ - 1985/89

\begin{tabular}{|c|c|c|c|}
\hline \multirow{2}{*}{$\begin{array}{l}\text { TOTAL MUNDIAL } \\
\text { Importações (efetivas) }\end{array}$} & \multicolumn{3}{|c|}{ Toneladas métricas } \\
\hline & $1979 / 84$ & $1985 / 89$ & \\
\hline Importação mundial & $28.033 .406,0$ & $27.808 .476,0$ & \\
\hline Exportação do Brasil & $2.562 .479,0$ & $1.984,166,6$ & (A2) \\
\hline Market-share (\%) & 9,14 & 7,14 & \\
\hline \multicolumn{4}{|c|}{ EXPORTAÇÕES POTENCIAIS DO BRASIL EM 1985/89 (Toneladas) } \\
\hline \multirow{4}{*}{$\begin{array}{l}\text { No mesmo market-share mundial } \\
\text { de } 1979 / 84 \\
\text { Na mesma participação de } 1979 / 84 \text {, } \\
\text { sendo que cada mercado manteve } \\
\text { constante sua participação individual }\end{array}$} & & & \\
\hline & & $2.541 .918,6$ & (B) \\
\hline & & & \\
\hline & & $2.242 .081,9$ & (C) \\
\hline GANHOS E PERDAS & Toneladas & (\%) & \\
\hline Ganho total (A2 - A1) & $-578.312,40$ & 100 & \\
\hline \multicolumn{4}{|l|}{ Efeitos: } \\
\hline Tamanho de mercado (B-A1) & $-20.560,41$ & 3,56 & \\
\hline Distribuição (C-B) & $-299.836,71$ & 51,85 & \\
\hline Competitividade (A2-C) & $-257.915,27$ & 44,60 & \\
\hline
\end{tabular}

Fonte: Elaborado a partir de dados da FAO Trade Yearbook; CACEX, e SECEX. 
O efeito competitividade negativo contribuiu com $44,60 \%$, provavelmente devido a fatores como elevados custos de comercialização e estrutura tributária (embora em termos de custo de produção fosse um dos mais baixos) e de fatores institucionais relacionados às políticas de abastecimento de álcool combustível em detrimento do açúcar para exportação. Como esse termo "competitividade" resulta praticamente como um resíduo nesse modelo, incorporando variáveis produtivas, macroeconômicas e políticas, é dificil discriminar quais sejam efetivamente os determinantes dessa perda na exportação. Finalmente, os restantes 3,56\% foram explicados pela redução no tamanho do mercado internacional de açúcar.

$O$ diferencial entre as quantidades comercializadas e as quantidades esperadas, apresentado na coluna (8) da Tabela 8 , relaciona-se tanto a fatores naturais como a fatores artificiais, conforme sugerem Konandreas \& Hurtado (1978). Os primeiros são aqueles fatores estruturais, inerentes aos próprios países, como por exemplo, o custo de transporte, podendo favorecer (ou não) a relação entre os mesmos. Os fatores artificiais, por sua vez, resultam de acordos preferenciais ou da adoção de medidas protecionistas, e sob os quais os países exportadores têm pouca ou nenhuma influência.

Os dados apresentados nas Tabelas 10 e 11 comparam o segundo subperíodo (1985/89) ao terceiro (1990/94). Nesse último, a fase de declínio das exportações brasileiras cedeu lugar a uma tendência de crescimento positivo, com a participação média passando de 7,14\% para $8,04 \%$ no mercado mundial. Considerando, como base de comparação, os principais importadores de açúcar do período 1979/84, constata-se que o Brasil aumentou ainda mais a sua participação na África. O resultado também foi positivo com relação ao mercado asiático, que apesar de não suprir grande parcela de suas necessidades com o produto brasileiro, importa quantidades bastante elevadas, que são significativas no total exportado pelo País.

As exportações brasileiras de açúcar para o mercado norte-americano no terceiro subperíodo também se recuperaram, tanto quanto ao volume exportado como à participação das mesmas no total importado pelos EUA, não voltando, contudo, a atingir a participação média que detinha no período 1979/84. As transações com os países da ex- 
Tabela 10 - Exportação média anual brasileira e mundial de açúcar nos subperíodos 1985/89 e 1990/94 em toneladas;participação do Brasil nos volumes importados de açúcar pelos seus principais importadores e por continentes

\begin{tabular}{|c|c|c|c|c|c|c|c|c|}
\hline \multirow{3}{*}{ Mercado } & \multicolumn{3}{|c|}{$1985 / 89$} & \multicolumn{3}{|c|}{$1990 / 94$} & \multicolumn{2}{|c|}{ Brasil $1990 / 94$ na $\%$ de $85 / 89$} \\
\hline & 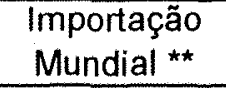 & $\begin{array}{c}\text { Exportação } \\
\text { Brasil }{ }^{\star \star *}\end{array}$ & $\begin{array}{l}\text { Participação } \\
\text { Brasil (\%) }\end{array}$ & $\begin{array}{l}\text { Importação } \\
\text { Mundial ** }\end{array}$ & $\begin{array}{l}\text { Exportação } \\
\text { Brasil }{ }^{* \star}\end{array}$ & $\begin{array}{l}\text { Participação } \\
\text { Brasil (\%) }\end{array}$ & $(3) \times(4)$ & $(5)-(7)$ \\
\hline & (1) & (2) & (3) & (4) & (5) & $(6)$ & (7) & (8) \\
\hline EUA & $1.766 .444,0$ & $144.913,5$ & 8,20 & $1.812 .360,0$ & $214.170,1$ & 11,82 & $148.680,3$ & $65.489,8$ \\
\hline Ex-URSS & $4.887 .576,0$ & $365.546,7$ & 7,48 & $4.727 .850,0$ & $180.306,6$ & 3,81 & $353.600,6$ & $-173.294,0$ \\
\hline Egito & $669.816,0$ & $130.481,3$ & 19,48 & $543.980,0$ & $161.853,9$ & 29,75 & $105.968,3$ & $55.885,6$ \\
\hline Argélia & $781.970,0$ & $107.041,8$ & 13,69 & $722.466,0$ & $26.385,1$ & 3,65 & $98.896,4$ & $-72.511,3$ \\
\hline Venezuela & $182.138,0$ & $26.230,0$ & 14,40 & $212.538,0$ & $3.360,0$ & 1,58 & $30.608,0$ & $-27.248,0$ \\
\hline Iraque & $574.892,0$ & $120.263,6$ & 20,92 & $420.256,0$ & $2.531,6$ & 0,60 & $87.914,8$ & $-85.383,2$ \\
\hline África* & $1.922 .316,0$ & $237.523,1$ & 12,36 & $2.480 .744,0$ & $764.766,0$ & 30,83 & $306.523,0$ & $458.243,0$ \\
\hline Am. Cent. e Norte ${ }^{*}$ & $1.242 .676,0$ & $144.913,5$ & 11,66 & $1.917 .418,0$ & $51.141,6$ & 2,67 & $223.597,9$ & $-172.456,3$ \\
\hline América do Sul & $259.332,0$ & $53.463,6$ & 20,62 & $636.942,0$ & $97.425,9$ & 15,30 & $131.337,4$ & $-33.911,5$ \\
\hline Ásia ${ }^{*}$ & $10.131 .726,0$ & $584.812,8$ & 5,77 & $10.136 .540,0$ & $659.460,8$ & 6,51 & $584.878,4$ & $74.582,5$ \\
\hline Europa & $5.182 .622,0$ & $76.730,2$ & 1,48 & $4.742 .936,0$ & $141.754,5$ & 2,99 & $70.220,5$ & $71.534,0$ \\
\hline Oceania & $206.984,0$ & $3.800,0$ & 1,84 & $232.096,0$ & - & 0,00 & $4.261,0$ & $-4.261,0$ \\
\hline TOTAL & $27.808 .476,0$ & $1.984 .166,6$ & 7,14 & $28.658 .854,0$ & $2.303 .156,1$ & 8,04 & $2.044 .842,0$ & $258.314,1$ \\
\hline Soma da coluna (7) & & & & & & & $2.146 .486,5$ & \\
\hline
\end{tabular}

* Os valores totais do grupo foram subtraídos das quantidades já consideradas dos 6 paises acima.

Fonte: Elaborado com dados da ${ }^{\star \star}$ FAO Trade Yearbook; ${ }^{* \star \star}$ CACEX/SECEX. 
Tabela 11 - Componentes do ganho/perda nas exportações brasileiras de açúcar. $1985 / 89-1990 / 94$

\begin{tabular}{|c|c|c|}
\hline \multirow{2}{*}{$\begin{array}{l}\text { TOTAL MUNDIAL } \\
\text { Importações (efetivas) }\end{array}$} & \multicolumn{2}{|c|}{ Toneladas métricas } \\
\hline & $1985 / 89$ & $1990 / 94$ \\
\hline Importação mundial & $27.808 .476,0$ & $28.658 .854,0$ \\
\hline Exportação do Brasil & $1.984 .166,6(\mathrm{~A} 1)$ & $2.303 .156,1$ \\
\hline Market-share (\%) & 7,14 & 8,04 \\
\hline \multicolumn{3}{|c|}{ EXPORTAÇÕES POTENCIAIS DO BRASIL EM 1990/94 (Toneladas) } \\
\hline \multicolumn{3}{|c|}{ No mesmo market-share mundial } \\
\hline de $1985 / 89$ & & $2.044 .842,0$ \\
\hline \multicolumn{3}{|l|}{$\begin{array}{l}\text { Na mesma participação de } 1985 / 89 \text {, } \\
\text { sendo que cada mercado manteve }\end{array}$} \\
\hline constante sua participação individual & & $2.146 .486,5 \quad(C)$ \\
\hline GANHOS E PERDAS & Toneladas & (\%) \\
\hline Ganho total (A2 - A1) & $318.989,54$ & 100 \\
\hline \multicolumn{3}{|l|}{ Efeitos: } \\
\hline Tamanho de mercado (B-A1) & $60.675,44$ & 19,02 \\
\hline Distribuição (C-B) & $101.644,50$ & 31,86 \\
\hline Competitividade (A2-C) & $156.669,60$ & 49,11 \\
\hline
\end{tabular}

Fonte: Elaborado a partir de dados da FAO Trade Yearbook; CACEX, e SECEX. 
URSS mantiveram sua tendência descendente, situação que, possivelmente, está relacionada aos problemas políticos existentes nesses países. É interessante ressaltar a recuperação das importações soviéticas de açúcar originado do Brasil, no ano de 1995, quando a Federação Russa importou mais de 1 milhão de toneladas do produto.

O mercado consumidor da ex-URSS merece atenção dos estrategistas comerciais do Brasil. Apesar de ser um mercado potencialmente atraente para os exportadores de açúcar, existem repúblicas dentro da própria região que podem vir a ser grandes fornecedoras desse produto para as repúblicas vizinhas. A Ucrânia, por exemplo, é responsável por $60 \%$ do total de açúcar produzido na ex-URSS, exportando uma parte considerável do mesmo. Confirmando esse panorama tem-se informações, divulgadas na Sugar Y Azucar (1996c), de que o governo ucraniano tem buscado investimentos para modernizar seu parque produtivo e adotar novas tecnologias visando estimular o setor.

O balanço total dessas transações, representado na Tabela 11 , sugere que a recuperação do Brasil no mercado internacional entre os subperiodos 1985/89 e 1990/94 resultou dos efeitos favoráveis gerados pela expansão do mercado mundial açucareiro, e por efeitos positivos na distribuição do mercado importador e na competitividade.

As Tabelas 12 e 13 permitem comparar os valores médios da participação do Brasil nos mercados importadores para o subperíodo inicial (1979/84) com relação ao subperíodo final (1990/94). Verifica-se como tendência geral, que nesses 16 anos, as perdas nos mercados norte-americano e na ex-URSS têm sido compensadas pelo acréscimo das exportações para mercados da África e da Ásia. Dentre esses, destacam-se a Nigéria, Angola, Marrocos, Sri-Lanka, Jordânia e Irã. Esses resultados indicam que houve uma diversificação dos mercados importadores de açúcar brasileiro. Para ilustrar essas modificações e a importância para o Brasil do mercado africano e asiático, observa-se que no subperíodo inicial, os volumes médios exportados de açúcar pelo País para os EUA e para a ex-URSS foram de 610,7 e 546,6 mil toneladas, respectivamente. 
Tabela 12 - Exportação média anual brasileira e mundialde açúcar nos subperiodos 1979/84 e 1990/94 em toneladas;e participação do Brasil nas quantidades importadas de açúcar pelos seus principais importadores e por continentes

\begin{tabular}{|c|c|c|c|c|c|c|c|c|}
\hline \multirow{3}{*}{ Mercado } & \multicolumn{3}{|c|}{$1979 / 1984$} & \multicolumn{3}{|c|}{$1990 / 94$} & \multicolumn{2}{|c|}{ Brasil $1990 / 94$ na $\%$ de $79 / 84$} \\
\hline & $\begin{array}{l}\text { Importação } \\
\text { Mundial ** }\end{array}$ & $\begin{array}{l}\text { Exportação } \\
\text { Brasil } \star \star \star \star\end{array}$ & $\begin{array}{l}\text { Participação } \\
\text { Brasil (\%) }\end{array}$ & $\begin{array}{l}\text { Importação } \\
\text { Mundial ** }\end{array}$ & $\begin{array}{l}\text { Exportação } \\
\text { Brasil }{ }^{\star \star \star}\end{array}$ & $\begin{array}{c}\text { Participação } \\
\text { Brasil }(\%)\end{array}$ & $(3) \times(4)$ & $(5)-(7)$ \\
\hline & (1) & $(2)$ & (3) & (4) & $(5)$ & (6) & (7) & (8) \\
\hline EUA & $3.518 .272,8$ & $610.666,0$ & 17,36 & $1.812 .360,0$ & $214.170,1$ & 11,82 & $314.571,0$ & $-100.400,91$ \\
\hline Ex-URSS & $5.573 .922,5$ & $546.635,0$ & 9,81 & $4.727 .850,0$ & $180.306,6$ & 3,81 & $463.660,6$ & $-283.354,05$ \\
\hline Egito & $640.014,0$ & $196.120,0$ & 30,64 & $543.980,0$ & $161.853,9$ & 29,75 & $166.692,2$ & $-4.838,37$ \\
\hline Argélia & $594.954,2$ & $187.180,0$ & 31,46 & $722.466,0$ & $26.385,1$ & 3,65 & $227.296,8$ & $-200.911,67$ \\
\hline Venezuela & $376.876,2$ & $166.884,0$ & 44,28 & $212.538,0$ & $3.360,0$ & 1,58 & $94.113,6$ & $-90.753,65$ \\
\hline Iraque & $552.409,3$ & $121.845,0$ & 22,06 & $420.256,0$ & $2.531,6$ & 0,60 & $92.695,9$ & $-90.164,32$ \\
\hline África* & $2.097 .030,8$ & $169.016,5$ & 8,06 & $2.480 .744,0$ & $764.766,0$ & 30,83 & $199.943,0$ & $564.822,95$ \\
\hline Am. Cent. e Norte ${ }^{\star}$ & $1.531 .583,5$ & $56.089,1$ & 3,66 & $1.917 .418,0$ & $51.141,6$ & 2,67 & $70.219,0$ & $-19.077,35$ \\
\hline América do Sul* & $357.253,2$ & $45.117,7$ & 12,63 & $636.942,0$ & $97.425,9$ & 15,30 & $80.439,7$ & $16.986,26$ \\
\hline Ásia* & $8.292 .360,2$ & $372.731,3$ & 4,49 & $10.136 .540,0$ & $659.460,8$ & 6,51 & $455.624,8$ & $203.836,00$ \\
\hline Europa & $4.295 .306,7$ & $90.194,1$ & 2,10 & $4.742 .936,0$ & $141.754,5$ & 2,99 & $99.593,6$ & $42.160,89$ \\
\hline Oceania & $203.589,3$ & - & 0,00 & $232.096,0$ & - & 0,00 & - & 0,00 \\
\hline TOTAL & $28.033 .406,0$ & $2.562 .479,0$ & 9,14 & $28.658 .854,0$ & $2.303 .156,1$ & 8,04 & $2.619 .650,0$ & $-316.493,85$ \\
\hline Soma da coluna (7) & & & & & & & $2.264 .850,3$ & \\
\hline
\end{tabular}

* Os valores totais do grupo foram subtraídos das quantidades já consideradas dos 6 países acima.

Fonte: Elaborado com dados da ${ }^{\star \star}$ FAO Trade Yearbook; ${ }^{\star \star \star}$ CACEX/SECEX. 
Figura 13 - Componentes do ganho/perda nas exportações brasileiras de açúcar. $1979 / 84-1990 / 94$

\begin{tabular}{|c|c|c|}
\hline \multirow{2}{*}{$\begin{array}{l}\text { TOTAL MUNDIAL } \\
\text { Importações (efetivas) }\end{array}$} & \multicolumn{2}{|c|}{ Toneladas métricas } \\
\hline & $1979 / 84$ & $1990 / 94$ \\
\hline Importação mundial & $28.033 .406,0$ & $28.658 .854,0$ \\
\hline Exportação do Brasil & $2.562 .479,0 \quad(\mathrm{~A} 1)$ & $2.303 .156,1$ \\
\hline Market-share (\%) & 9,14 & 8,04 \\
\hline \multicolumn{3}{|c|}{ EXPORTAÇÕES POTENCIAIS DO BRASIL EM 1990/94 (Toneladas) } \\
\hline \multicolumn{3}{|c|}{ No mesmo market-share mundial } \\
\hline de $1979 / 84 \quad$ (B) & & $2.619 .645,0$ \\
\hline \multicolumn{3}{|c|}{$\begin{array}{l}\text { Na mesma participação de } 1979 / 84 \\
\text { sendo que cada mercado manteve }\end{array}$} \\
\hline constante sua participação ind & idual (C) & $2.264 .850,3(C)$ \\
\hline GANHOS E PERDAS & Toneladas & $(\%)$ \\
\hline Ganho total (A2 - A1) & $-259.322,86$ & 100 \\
\hline \multicolumn{3}{|l|}{ Efeitos: } \\
\hline Tamanho de mercado (B-A1) & $57.170,98$ & $-22,05$ \\
\hline Distribuição (C-B) & $-354.799,65$ & 136,82 \\
\hline Competitividade (A2-C) & $38.305,81$ & $-14,17$ \\
\hline
\end{tabular}

Fonte: Elaborado a partir de dados da FAO Trade Yearbook; CACEX, e SECEX. 
Já no subperiodo 1990/94, a totalidade dos países da África e da Ásia foram responsáveis pela assimilação de 953 e 662 mil toneladas, respectivamente.

Os resultados apresentados na Tabela 13 mostram que o efeito competitividade e o efeito tamanho de mercado foram pouco expressivos sobre os resultados finais, não sendo suficientes para contrabalançar o efeito distribuição negativo. A constatação desse efeito distribuição negativo bastante significativo, como já foi dito, está relacionada à seleção dos mercados importadores discriminados pela análise. Os países selecionados que consistiam dos grandes mercados importadores brasileiros. em 1979/84 são justamente os mercados onde o Brasil perdeu representatividade, ao longo de 1985/1994. O Brasil ganhou "market-share" em vários países nesse mesmo intervalo, porém os mesmos não estão sendo analisados individualmente no estudo realizado.

A observação dos dados de exportação do Brasil desse período indica que países como a Índia e México, e em menor escala a China, são eventuais grandes compradores do Brasil. A Índia e a China destacam-se pela dimensão de seus mercados consumidores domésticos e pela sua grande produção. No caso do México, que em alguns anos aparece como importador e em outros como exportador de açúcar, a instituição do Acordo de Livre Comércio para a América do Norte (NAFTA) deve tender a modificar, no médio prazo, seu papel no comércio mundial de commodities.

Análise semelhante àquela apresentada nas Tabelas 8 a 13 foi conduzida utilizando uma outra forma de agregação do mercado importador. O objetivo da mesma foi verificar a existência de tendências diferentes das encontradas anteriormente, pelo fato dos países estudados serem agregados em blocos econômicos. Para tanto, além dos EUA, ex-URSS, África, Ásia e Oceania, foram desagregadas as quantidades exportadas para a União Européia daquelas exportadas para o restante da Europa (compreendendo, basicamente, os países da Europa Oriental). Da mesma forma foi feita distinção das exportações destinadas ao MERCOSUL (Argentina, Uruguai e Paraguai) daquelas destinadas aos demais países da América do Sul. As tabelas 14 a 19 mostram esses resultados para os mesmos subperiodos já mencionados. 
Tabela 14 -Média anual da importação mundial e da exportação brasileira de açúcar,nos subperíodos 1979/84 e 1985/89, em toneladas e participação do Brasil no total importado de açúcar por paises selecionados e por grupos de países

\begin{tabular}{|c|c|c|c|c|c|c|c|c|}
\hline \multirow{3}{*}{ Mercado } & \multicolumn{3}{|c|}{$1979 / 84$} & \multicolumn{3}{|c|}{$1985 / 89$} & \multicolumn{2}{|c|}{ Brasil 1985/89 na \% 1979/84 } \\
\hline & $\begin{array}{l}\text { Importação } \\
\text { Mundial ** }\end{array}$ & 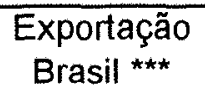 & $\begin{array}{c}\text { Participação } \\
\text { Brasil (\%) }\end{array}$ & $\begin{array}{l}\text { Importação } \\
\text { Mundial ** }\end{array}$ & $\begin{array}{c}\text { Exportação } \\
\text { Brasil }\end{array}$ & $\begin{array}{c}\text { Participação } \\
\text { Brasil (\%) }\end{array}$ & $(3) \times(4)$ & $(5)-(7)$ \\
\hline & $(1)$ & (2) & (3) & (4) & (5) & (6) & (7) & (8) \\
\hline EUA & $3.518 .272,8$ & $610.665,7$ & 17,36 & $1.766 .444,0$ & $144.913,5$ & 8,20 & $306.601,2$ & $-161.687,74$ \\
\hline Ex-URSS & $5.573 .922,5$ & $546.635,2$ & 9,81 & $4.887 .576,0$ & $365.546,7$ & 7,48 & $479.325,1$ & $-113.778,41$ \\
\hline MERCOSUL ${ }^{\star \star \star}$ & $8.806,8$ & 410,8 & 4,66 & $9.742,0$ & $1.442,1$ & 14,80 & 454,5 & 987,64 \\
\hline$U^{\star \star \star \star \star}$ & $3.050 .515,0$ & $67.310,0$ & 2,21 & $3.737 .426,0$ & $41.140,5$ & 1,10 & $82.466,8$ & $-41.326,24$ \\
\hline África & $3.331 .999,0$ & $552.316,5$ & 16,58 & $3.374 .102,0$ & $577.606,2$ & 17,12 & $559.295,6$ & $18.310,68$ \\
\hline Am. Central e Norte & $1.531 .583,5$ & $56.589,4$ & 3,69 & $1.242 .676,0$ & $175.713,6$ & 14,14 & $45.914,8$ & $129.798,77$ \\
\hline América do Sul & $725.322,5$ & $211.590,8$ & 29,17 & $431.728,0$ & $78.251,5$ & 18,13 & $125.943,5$ & $-47.692,03$ \\
\hline Ásia & $8.844 .769,5$ & $494.576,3$ & 5,59 & $10.706 .618,0$ & $705.076,4$ & 6,59 & $598.685,9$ & $106.390,43$ \\
\hline Europa & $1.244 .791,7$ & $22.884,1$ & 1,84 & $1.445 .196,0$ & $35.589,6$ & 2,46 & $26.568,3$ & $9.021,31$ \\
\hline Oceania & $203.589,3$ & 0,0 & 0,00 & $206.984,0$ & $3.800,0$ & 1,84 & 0,0 & $3.800,00$ \\
\hline Total & 28.033 .406 .0 & $2.562 .478,8$ & 9,14 & $27.808 .476,0$ & 1.984 .166 .6 & 7,14 & $2.541 .918,3$ & -557.751 .75 \\
\hline Soma da coluna (7) & & & & & & & $2.225 .255,7$ & \\
\hline
\end{tabular}

Fonte: Elaborado com dados da *FAO Trade Yearbook: ** CACEX/SECEX.

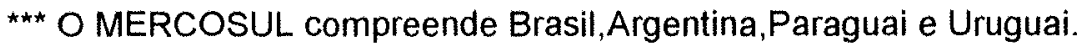

${ }^{* \star \star \star}$ A UE é composta pelos seguintes paises: Alemanha, Dinamarca, França,Holanda, Reino Unido, Bélgica, Irlanda, Grécia, Espanha, Finlândia, Portugal, Luxemburgo e Itália. 
Tabela 15 - Componentes do ganho/perda nas exportações brasileiras, no período 1979/84 - 1985/89

\begin{tabular}{|c|c|c|}
\hline \multirow{2}{*}{$\begin{array}{l}\text { TOTAL MUNDIAL } \\
\text { Importações (efetivas) }\end{array}$} & \multicolumn{2}{|c|}{ Toneladas métricas } \\
\hline & $1979 / 84$ & $1985 / 89$ \\
\hline Importação mundial & $28.033 .406,0$ & $27.808 .476,0$ \\
\hline Exportação do Brasil & $2.562 .478,8$ & $1.984 .166,6$ \\
\hline Market-share (\%) & 9,14 & 7,14 \\
\hline \multicolumn{3}{|c|}{ EXPORTAÇÕES POTENCIAIS DO BRASIL EM 1985/89 (Toneladas) } \\
\hline \multicolumn{3}{|c|}{ No mesmo market-share mundial } \\
\hline de $1979 / 84$ & & $2541918,3 \quad$ (B) \\
\hline \multirow{2}{*}{\multicolumn{3}{|c|}{$\begin{array}{l}\text { Na mesma participação de } 1979 / 84 \\
\text { sendo que cada mercado manteve } \\
\text { constante sua participação individual }\end{array}$}} \\
\hline & vidual & $2.225 .255,7(C)$ \\
\hline GANHOS EPERDAS & Toneladas & $(\%)$ \\
\hline Ganho total (A2 - A1) & $-578.312,16$ & 100 \\
\hline \multicolumn{3}{|l|}{ Efeitos: } \\
\hline Tamanho de mercado (B-A1) & $-20.560,41$ & 3,56 \\
\hline Distribuição (C-B) & $-316.662,69$ & 54,76 \\
\hline Competitividade (A2-C) & $-241.089,05$ & 41,69 \\
\hline
\end{tabular}

Fonte: Elaborado com dados da FAO Trade Yearbook e CACEX/SECEX. 
Tabela 16 -Média anual da importação mundial e da exportação brasileira de açúcar, nos subperiodos 1979/84 e 1985/89,em toneladas: e participação do Brasil no total importado de açúcar por paises selecionados e por grupos de países

\begin{tabular}{|c|c|c|c|c|c|c|c|c|}
\hline \multirow{3}{*}{ Mercado } & \multicolumn{3}{|c|}{$1985 / 89$} & \multicolumn{3}{|c|}{$1990 / 94$} & \multicolumn{2}{|c|}{ Brasil 1990/94 na $\% 1985 / 89$} \\
\hline & $\begin{array}{l}\text { Importação } \\
\text { Mundial ** }\end{array}$ & $\begin{array}{c}\text { Exportação } \\
\text { Brasil }{ }^{\star \star \star}\end{array}$ & $\begin{array}{c}\text { Participação } \\
\text { Brasil (\%) }\end{array}$ & $\begin{array}{l}\text { Importação } \\
\text { Mundial ** }\end{array}$ & $\begin{array}{c}\text { Exportação } \\
\text { Brasil } * \star \star\end{array}$ & $\begin{array}{c}\text { Participação } \\
\text { Brasil }(\%)\end{array}$ & $(3) \times(4)$ & $(5)-(7)$ \\
\hline & (1) & (2) & (3) & (4) & $(5)$ & $(6)$ & (7) & (8) \\
\hline EUA & $1.766 .444,0$ & $144.913,5$ & 8,20 & $1.812 .360,0$ & $\overline{214.170,1}$ & 11,82 & $148.680,3$ & $\overline{65.489,8}$ \\
\hline Ex-URSS & $4.887 .576,0$ & $365.546,7$ & 7,48 & $4.727 .850,0$ & $180.306,6$ & 3,81 & $353.600,6$ & $-173.294,0$ \\
\hline MERCOSUL ${ }^{\star \star \star}$ & $9.742,0$ & $1.442,1$ & 14,80 & $135.534,0$ & $59.293,0$ & 43,75 & $20.063,0$ & $39.230,0$ \\
\hline$U E^{\star \star \star \star}$ & $3.737 .426,0$ & $41.140,5$ & 1,10 & $3.519 .872,0$ & $79.257,3$ & 2,25 & $38.745,8$ & $40.511,6$ \\
\hline África & $3.374 .102,0$ & $577.606,2$ & 17,12 & $3.747 .190,0$ & $953.005,0$ & 25,43 & $641.474,5$ & $311.530,5$ \\
\hline Am.Central e Norte & $1.242 .676,0$ & $175.713,6$ & 14,14 & $1.917 .418,0$ & $51.141,6$ & 2,67 & $271.121,6$ & $-219.980,0$ \\
\hline América do Sul & $431.728,0$ & $78.251,5$ & 18,13 & $713.946,0$ & $41.493,0$ & 5,81 & $129.404,0$ & $-87.911,1$ \\
\hline Ásia & $10.706 .618,0$ & $705.076,4$ & 6,59 & $10.556 .796,0$ & $661.992,4$ & 6,27 & $695.209,9$ & $-33.217,5$ \\
\hline Europa & $1.445 .196,0$ & $35.589,6$ & 2,46 & $1.223 .064,0$ & $62.497,1$ & 5,11 & $30.119,4$ & $32.377,8$ \\
\hline Oceania & $206.984,0$ & $3.800,0$ & 1,84 & $232.096,0$ & 0,0 & 0,00 & $4.261,0$ & $-4.261,0$ \\
\hline Total & $27.808 .476,0$ & $1.984 .166,6$ & 7,14 & $28.658 .854,0$ & $2.303 .156,1$ & 8,04 & $2.044 .842,0$ & $258.314,1$ \\
\hline Soma da coluna (7) & & & & & & & $2.332 .680,1$ & \\
\hline
\end{tabular}

Fonte: Elaborado com dados da * FAO Trade Yearbook; ${ }^{* *}$ CACEX/SECEX.

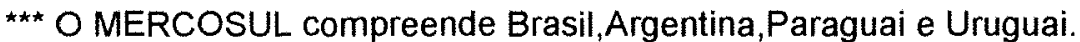

${ }^{\star \star \star \star}$ A UE é composta pelos seguintes países: Alemanha, Dinamarca, França,Holanda, Reino Unido, Bélgica,Irlanda, Grécia, Espanha, Finlândia, Portugal, Luxemburgo e Itália. 
Tabela 17 - Componentes do ganho/perda nas exportações brasileiras, no período $1985 / 89-1990 / 94$

\begin{tabular}{|c|c|c|}
\hline TOTAL MUNDIAL & Toneladas & métricas \\
\hline Importações (efetivas) & $1985 / 89$ & $1990 / 94$ \\
\hline Importação mundial & $27.808 .476,0$ & $28.658 .854,0$ \\
\hline Exportação do Brasil & $1.984 .166,6(\mathrm{~A} 1)$ & $2.303 .156,1$ \\
\hline Market-share (\%) & 7,14 & 8,04 \\
\hline EXPORTAÇŌES POTENCIAIS DO E & 3RASIL EM 1990/94 & (Toneladas) \\
\hline No mesmo market-share mundial & & \\
\hline de $1985 / 89$ & & $2.044 .842,0 \quad$ (B) \\
\hline Na mesma participação de $1985 / 89$, & & \\
\hline constante sua participação individual & & $2.332 .680,1 \quad$ (C) \\
\hline GANHOS E PERDAS & Toneladas & (\%) \\
\hline Ganho total $(A 2-A 1)$ & $318.989,53$ & 100 \\
\hline Efeitos: & & \\
\hline Tamanho de mercado (B-A1) & $60.675,44$ & 19,02 \\
\hline Distribuição (C-B) & $287.838,06$ & 90,23 \\
\hline Competitividade (A2-C) & $-29.523,97$ & $-9,26$ \\
\hline
\end{tabular}

Fonte: Elaborado com dados da FAO Trade Yearbook e CACEXISECEX. 
Tabela 18 - Média anual da importação mundial e exportação brasileira de açúcar, nos subperíodos 1979/84 e 1990/94, em toneladas; e participação do Brasil no total importado de açúcar por países selecionados e por grupos de países

\begin{tabular}{|c|c|c|c|c|c|c|c|c|}
\hline \multirow{3}{*}{ Mercado } & \multicolumn{3}{|c|}{$1979 / 84$} & \multicolumn{3}{|c|}{$1990 / 94$} & \multicolumn{2}{|c|}{ Brasil1990/94 na \% 1979/84 } \\
\hline & $\begin{array}{l}\text { Importação } \\
\text { Mundial ** }\end{array}$ & $\begin{array}{c}\text { Exportação } \\
\text { Brasil } \star \star \star \star\end{array}$ & $\begin{array}{c}\text { Participação } \\
\text { Brasil (\%) }\end{array}$ & $\begin{array}{l}\text { Importação } \\
\text { Mundial ** }\end{array}$ & $\begin{array}{c}\text { Exportação } \\
\text { Brasil } \star \star \star \star\end{array}$ & $\begin{array}{c}\text { Participação } \\
\text { Brasil }(\%)\end{array}$ & $(3) \times(4)$ & $(5)-(7)$ \\
\hline & (1) & (2) & (3) & (4) & (5) & (6) & (7) & (8) \\
\hline$\overline{E U A}$ & $3.518 .272,8$ & $610.665,7$ & 17,36 & $1.812 .360,0$ & $214.170,1$ & 11,82 & $314.570,8$ & $-100.400,7$ \\
\hline EX-URSS & $5.573 .922,5$ & $546.635,2$ & 9,81 & $4.727 .850,0$ & $180.306,6$ & 3,81 & $463.660,7$ & $-283.354,2$ \\
\hline MERCOSUL ${ }^{\star \star \star}$ & $8.806,8$ & 410,8 & 4,66 & $135.534,0$ & $59.293,0$ & 43,75 & $6.322,6$ & $52.970,4$ \\
\hline$U E^{\star \star \star \star}$ & $3.050 .515,0$ & $67.310,0$ & 2,21 & $3.519 .872,0$ & $79.257,3$ & 2,25 & $77.666,4$ & $1.590,9$ \\
\hline África & $3.331 .999,0$ & $552.316,5$ & 16,58 & $3.747 .190,0$ & $953.005,0$ & 25,43 & $621.139,1$ & $331.865,9$ \\
\hline Am.Central e Norte & $1.531 .583,5$ & $56.589,4$ & 3,69 & $1.917 .418,0$ & $51.141,6$ & 2,67 & $70.845,4$ & $-19.703,7$ \\
\hline América do Sul & $725.322,5$ & $211.590,8$ & 29,17 & $713.946,0$ & $41.493,0$ & 5,81 & $208.272,1$ & $-166.779,1$ \\
\hline Ásia & $8.844 .769,5$ & $494.576,3$ & 5,59 & $10.556 .796,0$ & $661.992,4$ & 6,27 & $590.308,3$ & $71.684,2$ \\
\hline Europa & $1.244 .791,7$ & $22.884,1$ & 1,84 & $1.223 .064,0$ & $62.497,1$ & 5,11 & $22.484,7$ & $40.012,5$ \\
\hline Oceania & $203.589,3$ & 0,0 & 0,00 & $232.096,0$ & 0,0 & 0,00 & 0,0 & 0,0 \\
\hline Total & $28.033 .406,0$ & $2.562 .478,8$ & 9,14 & $28.658 .854,0$ & $2.303 .156,1$ & 8,04 & $2.619 .649,7$ & $-316.493,6$ \\
\hline Soma da coluna (7) & & & & & & & $2.375 .270,1$ & \\
\hline
\end{tabular}

Fonte: Elaborado com dados da *FAO Trade Yearbook; ${ }^{\star *}$ CACEX/SECEX.

*** O MERCOSUL compreende Brasil,Argentina,Paraguai e Uruguai.

${ }^{\star * \star \star}$ A UE é composta pelos seguintes países: Alemanha, Dinamarca, França,Holanda, Reino Unido, Bélgica,Irlanda, Grécia, Espanha, Finlândia, Portugal, Luxemburgo e Itália. 
Tabela 19 - Componentes do ganho/perda nas exportações brasileiras, no periodo 1979/84 - 1990/94

\begin{tabular}{|c|c|c|}
\hline \multirow{2}{*}{$\begin{array}{l}\text { TOTAL MUNDIAL } \\
\text { Importações (efetivas) }\end{array}$} & \multicolumn{2}{|c|}{ Toneladas métricas } \\
\hline & $1979 / 84$ & $1990 / 94$ \\
\hline Importação mundial & $28.033 .406,0$ & $28.658 .854,0$ \\
\hline Exportação do Brasil & $2.562 .478,8 \quad(A 1)$ & $2.303 .156,1$ \\
\hline Market-share (\%) & 9,14 & 8,04 \\
\hline \multicolumn{3}{|c|}{ EXPORTAÇŌES POTENCIAIS DO BRASIL EM 1990/94 (Toneladas) } \\
\hline \multicolumn{3}{|c|}{ No mesmo market-share mundial } \\
\hline \multirow{2}{*}{\multicolumn{3}{|c|}{$\begin{array}{l}\text { Na mesma participação de } 1979 / 84 \text {, } \\
\text { sendo que cada mercado manteve } \\
\text { constante sua participação individual }\end{array}$}} \\
\hline & & $2.375 .270,1 \quad(C)$ \\
\hline GANHOS E PERDAS & Toneladas & (\%) \\
\hline Ganho total (A2 - A1) & $-259.322,70$ & 100 \\
\hline \multicolumn{3}{|l|}{ Efeitos: } \\
\hline Tamanho de mercado (B-A1) & $57.170,90$ & $-22,05$ \\
\hline Distribuição (C-B) & $-244.379,60$ & 94,24 \\
\hline Competitividade (A2-C) & $-72.114,00$ & 27,81 \\
\hline
\end{tabular}

Fonte: Elaborado com dados da FAO Trade Yearbook e CACEX/SECEX. 
Os resultados observados nessa análise proposta indicam que as conclusões da comparação do primeiro terço do período com o segundo (Tabela 9) basicamente não diferiram daquelas obtidas anteriormente (Tabela 15).

Contudo, verificam-se algumas diferenças entre as análises quando se compara o subperiodo recessivo (1985/89) e o último subperíodo (1990/94). Os resultados da Tabela 17 identificam um efeito competitividade discretamente negativo e um efeito distribuição largamente favorável, divergindo do resultado apresentado na Tabela 11 para o intervalo estudado. Apesar disso, o saldo final encontrado foi positivo e de mesma magnitude. A divergência nos resultados quando se empregam diferentes níveis de agregação dos países era esperada, tendo sido mencionada por Richardson (1971) e Rigaux (1971).

Esta segunda forma de agregação dos países importadores permite observar que as importações dos países do MERCOSUL aumentaram no subperíodo 1990/94, assim como a participação do Brasil como fornecedor de açúcar para esse mercado. O MERCOSUL pode oferecer boas perspectivas para o setor sucroalcooleiro do Brasil, embora limitadas ao mercado argentino para o açúcar, cujas proporções são consideráveis quando comparadas às dos mercados consumidores do Paraguai e Uruguai. A Argentina importou mais de 200 mil toneladas nos anos de 1994 e 1995. Quanto à política comum a ser adotada pelos quatro países em relação às misturas combustiveis, o Brasil poderá beneficiar-se caso seja definida uma porcentagem fixa e representativa de etanol a ser adicionada obrigatoriamente à gasolina. Além disso, a adesão de outras nações como membros desse mercado comum, também pode beneficiar o setor exportador brasileiro.

A participação do Brasil como exportador de açúcar para os demais países da América do Sul reduziu-se ao longo do período analisado, sendo que no primeiro subperíodo o País era responsável por suprir 29,17\% das importações dessa região, caindo no terceiro subperíodo para apenas 5,81\% do total (Tabela 18). Destaca-se a redução do "market-share" brasileiro no mercado da Venezuela, que é um dos maiores importadores de açúcar da região. 
Já as transações desse produto entre o Brasil e os paises da União Européia (UE) mantiveram-se praticamente estáveis (em termos quantitativos) ao longo dos dezesseis anos analisados, representando muito pouco para o Brasil em termos do total de suas exportações. Por outro lado, o açúcar brasileiro representa também uma parcela discreta das importações totais da UE.

Quanto aos demais países da Europa, a participação do Brasil em suas importações apresentou evolução favorável, crescendo de $1,84 \%$ para $5,11 \%$, entre 1979/84 e 1990/94, embora em termos de volume comercializado, esse valor represente muito pouco (Tabela 18). Dentre esses países da Europa, destacam-se as participações da Bulgária, Romênia e Portugal.

A comparação entre os resultados relativos ao subperíodo inicial e final, apresentados nas Tabelas 18 e 19, indica um efeito distribuição de menor intensidade nesta segunda forma de agregação em relação à anterior (Tabelas 12 e 13). O efeito competitividade observado também apresentou-se negativo, já que o País, na média para o subperíodo 1990/94, não conseguiu atingir o "market-share" médio que detinha em 1979/84. Os resultados confirmaram os anteriores quanto à perda em participação do açúcar brasileiro no mercado norte-americano e no soviético, ao aumento no mercado africano e uma certa estabilidade no asiático.

Rigaux (1971) alerta que o efeito competitividade pode apresentar-se desfavorável ao exportador quando ocorre uma expansão da demanda doméstica pelo produto. Essa situação é passivel de ser considerada para o mercado brasileiro durante o período analisado, dadas as dimensões da população e a sua baixa renda per capita, que podem tornar o mercado doméstico brasileiro, responsável pela absorção de potenciais aumentos nos excedentes de açúcar. No caso específico do Brasil, a relação estrutural existente entre a produção de açúcar e de álcool possivelmente causou alterações na competitividade do produto nacional no mercado externo em períodos passados. 


\subsubsection{Análise de "market-share" - Crescimento das exportações e Grau de} Preferência

A análise do mercado internacional de açúcar discriminando as relações de quantidades e preços por país exportador/país destinatário, não foi possivel para todos os países exportadores devido à dificuldade na obtenção dos dados desagregados por destino. Diante dessa limitação, estabeleceu-se um mercado exportador dividido em Brasil, Cuba e Resto do Mundo, e um mercado importador consistindo da ex-União Soviética, China/Japão (tomados em conjunto) e Resto do Mundo. A análise compreendeu o período de 1982 a 1994.

Os paises selecionados apresentam papel significativo nos mercados em que atuam. A soma das participações de Brasil e Cuba totalizou 35\% do mercado de exportação de açúcar em 1984, e $23 \%$ em 1994. No mercado importador a ex-URSS, China e Japão também se destacaram por concentrar em média 20 a $30 \%$ da demanda mundial por açúcar nesse mesmo período. A Tabela 20 apresenta as taxas de crescimento e a participação média dos principais mercados exportadores e importadores na comercialização mundial de açúcar, parâmetros úteis para a discussão dos resultados. As taxas geométricas de crescimento foram estimadas pelo método de Mínimos Quadrados Ordinários ${ }^{30}$.

As taxas estimadas mostram que o crescimento das exportações mundiais foi positivo ao longo do periodo analisado, embora pequeno, destacando-se a evolução favorável da Tailândia, Brasil, Austrália e Alemanha, e as taxas negativas de outros tradicionais exportadores como Cuba, República Dominicana, África do Sul e Filipinas. O

\footnotetext{
${ }^{30}$ Partindo da expressão: $X_{t}=X_{0}(1+r)$$$
\log X_{t}=\log X_{0}+t \log (1+r)
$$

Essa expressão pode ser estimada na forma:

$$
\mathrm{Y}=\mathbf{a}+\mathbf{b t}
$$

na qual $b=\log (1+r)$. A taxa geométrica pode, então, ser calculada por:

$$
r=e^{b}-1
$$
}

considera-se que $\mathrm{X}_{\mathrm{t}}$ é a quantidade exportada por um país no tempo $t, \mathrm{X}_{0}$ é a quantidade exportada no período inicial, $t$ é o período em anos, e $r$ é a taxa de crescimento geométrica das quantidades exportadas. Tomando-se o logaritmo neperiano da expressão acima e rearranjando os termos, tem-se que: 
Brasil apresentou a segunda maior taxa de crescimento $(3,82 \%)$ entre os maiores exportadores de açúcar, ficando abaixo apenas da Tailândia $(8,76 \%)$. Quanto às importações, os dados revelam que houve saldo positivo no crescimento por parte dos países da África, Ásia e Europa (incluindo os países da UE e da Europa Oriental) e negativo para países grandes importadores como os Estados Unidos e a ex-URSS.

Tabela 20 - Taxas de crescimento das exportações e importações mundiais de açúcar total para mercados selecionados. participação média dos paises no mercado mundial 1979-1994

\begin{tabular}{lcc}
\hline País & $\begin{array}{c}\text { Taxa de Crescimento } \\
(\%)\end{array}$ & $\begin{array}{c}\text { Participação média dos } \\
\text { países no mercado } \\
\text { mundial }(\%)\end{array}$ \\
\hline Mercado exportador mundial & 0,40 & - \\
África do Sul & $-5,98$ & 2,54 \\
Cuba & $-3,04$ & 21,85 \\
Rep. Dominicana & $-8,16$ & 2,09 \\
Filipinas & $-1,52$ & 2,14 \\
Tailândia & 8,76 & 6,96 \\
França & 0,49 & 9,25 \\
Alemanha * & 3,19 & 4,31 \\
Austrália & 2,22 & 8,94 \\
Brasil & 3,82 & 8,30 \\
Mercado importador mundial & 0,28 & - \\
África & 1,27 & 12,35 \\
Egito & $-1,48$ & 2,20 \\
Argélia & 2,20 & 2,47 \\
Nigéria & $-3,72$ & 2,02 \\
Ásia & 1,66 & 35,41 \\
China & $-1,13$ & 5,38 \\
Japão & $-1,55$ & 6,73 \\
República da Coréia & 4,70 & 3,46 \\
Irã & $-1,29$ & 2,14 \\
Iraque & $-2,79$ & 1,85 \\
Ex-URSS & $-1,01$ & 18,05 \\
Europa & 1,29 & 16,73 \\
Reino Unido & 0,17 & 4,70 \\
Canadá & 0,81 & 3,50 \\
Estados Unidos & $-6,41$ & 8,71 \\
\hline Fonte: elaborado com & & \\
\hline
\end{tabular}

Fonte: elaborado com dados da FAO Trade Yearbook.

* Até 1991 os valores utilizados para os cálculos foram computados como a soma da República Federal da Alemanha e da República Democrática Alemã. 
Os dados de participação média no mercado mundial evidenciam que Cuba destacou-se como o maior exportador mundial ${ }^{31}$ para esse período. Recentemente, devido aos problemas climáticos e político-econômicos de Cuba, o País teve seu "marketshare" ainda mais reduzido no mercado exportador de açúcar, concentrando apenas $10,67 \%$ das exportações mundiais totais na safra 1995/96.

Os dados apresentados por Burnquist (1996) confirmam que a classificação dos maiores exportadores de açúcar se alterou sendo que, a partir de 1992/93, a União Européia passou a constar como a maior exportadora do produto. Os dados apresentados pela autora mostram, ainda, que nas duas últimas safras, o Brasil ficou em segundo lugar, seguido pela Austrália e Tailândia, enquanto Cuba passou à quinta colocação.

A Tabela 21 contém os resultados da análise segundo o procedimento proposto por Konandreas \& Hurtado (1978). Os volumes médios exportados indicam que o Brasil vem alcançando no terceiro subperíodo (1990/94) a quantidade exportada média do primeiro subperíodo (1982/84), após uma fase de queda pronunciada entre 1985 e 1989. Verifica-se que Cuba, ao contrário, vem apresentando redução nas quantidades exportadas.

Dados mais atualizados mostram que as tendências discutidas acima ainda vêm se mantendo para esses mercados. No ano safra 1995/96, foram exportadas 5.200.000 toneladas de açúcar pelo Brasil, 3.200.000 toneladas por Cuba e 21.617.000 toneladas pelo Resto do Mundo, segundo informações divulgadas pela USDA (citado por Burnquist, 1996).

Os valores calculados de "export-shares" (participação dos paises nas exportações mundiais) para o Brasil, Cuba e Resto do Mundo são apresentados na Tabela 21 , verificando-se que entre o primeiro subperíodo analisado (1982/84) e o segundo (1985/89) houve perda de representatividade do Brasil e de Cuba nas exportações totais mundiais. Contudo, no terceiro subperíodo, o Brasil conseguiu reverter essa tendência descendente atingindo participação média de 8,04\%. Especificamente, no ano de 1994,

${ }^{31}$ É importante fazer a ressalva de que os paises da União Européia estão sendo considerados individualmente nesta análise. 
essa participação foi de 12,63\%. A participação de Cuba manteve-se decrescente, passando de $25,18 \%$, em 1982/84, para 18,74\% em 1990/94. Observa-se, como já era esperado, que a participação do Resto do Mundo aumentou ao longo do periodo, sugerindo que a parcela perdida por Cuba e pelo Brasil foi apropriada por outros paises exportadores.

Tabela 21 - Participação dos países exportadores selecionados nas exportações mundiais $\left(\mathrm{x}_{\mathrm{i}}\right)$, Índice de Concentração Geográfica das exportações e participação dos importadores no total vendido pelos exportadores $\left(\mathrm{m}_{\mathrm{ij}}\right)$

\begin{tabular}{|c|c|c|c|c|c|c|}
\hline \multirow[t]{2}{*}{$\begin{array}{l}\text { Origem das } \\
\text { Exportações }\end{array}$} & \multirow{2}{*}{$\begin{array}{c}\text { Volume } \\
\text { Exportado - } \\
\text { Média anual }\left(X_{i}\right) \\
\text { (Toneladas) }\end{array}$} & \multirow{2}{*}{$\begin{array}{c}\text { Participação nas } \\
\text { Exportações } \\
\text { Mundiais }\left(\mathrm{x}_{\mathrm{i}}\right) \\
(\%)\end{array}$} & \multirow{2}{*}{$\begin{array}{c}\text { Índice de } \\
\text { Concentração } \\
\text { Geográfica das } \\
\text { Exportações }\end{array}$} & \multicolumn{3}{|c|}{$\begin{array}{c}\text { Destino das Exportações } \\
\left(\mathrm{m}_{\mathrm{ij}}\right)\end{array}$} \\
\hline & & & & Ex-URSS & $\begin{array}{l}\text { Japão e } \\
\text { China }\end{array}$ & $\begin{array}{l}\text { Resto do } \\
\text { Mundo }\end{array}$ \\
\hline \multicolumn{7}{|l|}{ Brasil } \\
\hline $1982 / 84$ & 2.757 .472 & 9,67 & 75,77 & 27,44 & 1,97 & 70,60 \\
\hline $1985 / 89$ & 1.984 .166 & 7,14 & 80,20 & 18,42 & 3,61 & 77,97 \\
\hline 1990/94 & 2.303 .156 & 8,04 & 92,50 & 7,83 & 0,00 & 92,17 \\
\hline \multicolumn{7}{|l|}{ Cuba } \\
\hline $1982 / 84$ & 7.181 .000 & 25,18 & 63,61 & 52,88 & 15,19 & 31,94 \\
\hline $1985 / 89$ & 6.899 .000 & 24,81 & 63,40 & 53,25 & 16,62 & 30,13 \\
\hline $1990 / 94$ & 5.371 .200 & 18,74 & 63,27 & 52,35 & 15,85 & 31,80 \\
\hline \multicolumn{7}{|c|}{ Resto do Mundo } \\
\hline $1982 / 84$ & 18.585 .602 & 65,16 & 78,29 & 9,87 & 13,67 & 76,46 \\
\hline $1985 / 89$ & 18.925 .310 & 68,06 & 82,76 & 4,48 & 14,09 & 81,43 \\
\hline $1990 / 94$ & 20.984 .498 & 73,22 & 82,28 & 9,24 & 9,57 & 81,20 \\
\hline
\end{tabular}

Fonte: Elaborado pelo autor segundo dados da FAO Trade Yearbook, CACEX/DECEX e ISO (Internet).

Entre esses outros exportadores, é possivel destacar o desempenho da Austrália e da Tailândia, cujas participações no mercado exportador passaram de $6,95 \%$ e $4,49 \%$ em 1979, para $11,91 \%$ e $9,21 \%$ em 1994, respectivamente, segundo cálculos elaborados com dados da FAO Trade Yearbook. O crescimento pronunciado das exportações de açúcar por esses dois países têm sido destacado em literatura relacionada. Segundo Abbott (1990) o crescimento das exportações nesses países foi alavancado, principalmente, pela alta de preços verificada em 1974. 
Os resultados apresentados na Tabela 21 revelam que as importações de açúcar da ex-URSS detiveram, em média, 27,44\% do açúcar exportado pelo Brasil no primeiro subperiodo, participação essa que caiu para $7,83 \%$ no último quinquênio analisado. Esse mesmo importador caracterizou-se nos três subperiodos por deter mais de $50 \%$ do total exportado por Cuba.

A constância nas relações comerciais entre Cuba e seus parceiros constatada por este trabalho e confirmada pela literatura correspondente, foi justificada por Abbott (1990) pela existência dos acordos preferenciais mantidos entre esse País e os demais países socialistas, os quais no período entre 1977 e 1986 foram responsáveis, em média, por $68,3 \%$ do total de açúcar exportado anualmente por $\mathrm{Cuba}^{32}$. Essas transações atuaram de forma a isolar Cuba das negociações e da competição existente no restante do mercado mundial.

A participação do Japão e da China como importadores do Brasil não atingiu proporções elevadas, conforme indicado na Tabela 21 , tendo representado, no máximo, um valor médio de $3,61 \%$ no segundo subperíodo, regredindo para zero no último subperíodo. Os dados de exportação permitem concluir que a presença da China como comprador de açúcar do Brasil foi esporádica, havendo anos em que esse importador comprou grandes volumes (por exemplo, em 1988 e 1995) e outros em que nem sequer constou da relação de importadores brasileiros (1990 a 1994).

A proporção exportada para o Japão/China no total exportado por Cuba manteve-se praticamente estável ao longo de todo o período, num patamar acima de $15 \%$, indicando a importância desse mercado importador para o referido país. Apesar disso, em termos absolutos, o volume de açúcar exportado por Cuba com destino a esses dois paises reduziu-se ao longo do periodo analisado.

Informações divulgadas pela Sugar Y Azucar (1996b) confirmam essas alterações nos relacionamentos comerciais do Japão e da China referentes ao açúcar cubano. Segundo essa mesma fonte, tem-se verificado um aumento das exportações açucareiras da Austrália e da Tailândia com destino a esses dois importadores.

\footnotetext{
${ }^{32}$ Esses acordos preferenciais envolviam além da ex-URSS e a China, paises da Europa Oriental (Bulgária, Checoslováquia, Hungria, Iugoslávia, Polônia) e Coréia do Norte, entre outros (Abbott, 1990).
} 
Japão e China apresentaram participação decrescente como importadores de açúcar do Resto do Mundo comparando-se o subperíodo inicial e final da análise. Nesse período final, os dois países detiveram apenas 9,57\% das exportações do Resto do Mundo. Verifica-se ainda que o Japão e a China vem reduzindo, generalizadamente, suas importações de açúcar, embora em valores médios para o periodo 1979/94, constem como o terceiro e quarto maiores importadores mundiais (Tabela 20).

A fim de compreender as modificações constatadas para os mercados da China e do Japão, considera-se conveniente tecer alguns comentários sobre os dois importadores. Nas safras de 1992/93 a 1994/95 a produção chinesa de açúcar caiu do patamar de 8,0 milhões para 6,0 milhões de toneladas. Apesar disso, o governo vem mantendo sua política de restringir as importações (e fixar preços da cana, e do açúcar no varejo) como forma de estimular a produção interna (Sugar Y Azucar, 1996b). Contudo, a expectativa com relação à China é de que o País continue a ser um dos maiores compradores de açúcar em função de fatores como a demanda interna crescente pelo produto, o crescimento da produção inferior ao da demanda doméstica; e a deterioração do seu relacionamento comercial açucareiro com Cuba (CHINA'S changing, 1994).

O caso do Japão é diferente assim como as perspectivas com relação ao seu papel futuro como importador de açúcar. Recentemente, apenas $15 \%$ do açúcar bruto destinado à refinação é de origem japonesa, sendo que a importação em quantidades absolutas vem diminuindo bem como seu consumo, nas duas últimas décadas. Alguns fatores responsáveis pelo novo contexto no mercado açucareiro japonês podem ser mencionados: o aumento na importação de produtos industrializados que contêm açúcar; a redução na demanda industrial de açúcar devido, principalmente, à substituição pelo xarope de milho (HFCS); e o período recessivo pelo qual passou a economia japonesa. A importância desses fatores foi ressaltada por Buzanell (1994).

O Índice de Concentração Geográfica das exportações, calculado pela equação (19) e utilizado para avaliar o grau de diversificação das exportações de um país, deve ser analisado com cautela. O valor máximo que o índice pode atingir é 100, indicando especialização máxima do país exportador, o que corresponderia a atender apenas a um único importador. No outro extremo, o valor mínimo que o índice pode 
atingir neste caso é de $57,74^{33}$, indicando grau máximo de diversificação do país exportador (dados os importadores considerados). A ressalva que deve ser feita é quanto à representatividade desta medida. Resultados mais apurados são obtidos quando se divide o mercado importador de forma a englobar, individualmente, o número máximo de paises relevantes para a caracterização do mercado, o que não foi totalmente possível no presente trabalho devido à falta de dados.

Os valores do índice calculados para o Brasil indicam uma redução na diversificação dos mercados importadores, provocada pelo aumento percentual do Resto do Mundo e pela redução da participação da ex-URSS, Japão e China nas exportações brasileiras. Como o Resto do Mundo engloba uma parcela muito grande do mercado importador brasileiro essa concepção de concentração fica restrita apenas à análise do mercado importador discriminado. As estatísticas levantadas pela CACEX/SECEX permitem afirmar que em 1995, o Brasil comercializou açúcar com 64 países diferentes, enquanto em 1979, eram apenas 44 paises, indicando uma tendência de diversificação e não de concentração na composição de seu mercado importador.

Os patamares em que se mantiveram as participações dos países importadores no mercado cubano foram estáveis, de forma que esse índice também ficou estacionário em pouco mais de $60 \%$, podendo ser considerado como um valor médio de concentração do mercado importador.

A Tabela 22 apresenta os volumes médios exportados de açúcar nos três subperíodos analisados (1982/84, 1985/89 e 1990/94), discriminados por pais importador. As importações da ex-URSS apresentaram tendência descendente, tanto para as quantidades comercializadas como para a participação percentual do País no total mundial importado. É interessante comentar que apesar desse desempenho, a ex-URSS ainda constitui o maior importador individual de açúcar, tendo sido responsável por $13,35 \%$ do total mundial importado em 1994 .

\footnotetext{
${ }^{33}$ Esse valor é obtido quando os três mercados importadores dividem igualmente o total das exportações do país exportador, tendo-se então:

$$
\sqrt{(33,33)^{2}+(33,33)^{2}+(33,33)^{2}}=57,74
$$
}


Os resultados apontados na Tabela 22 confirmam que as importações totais do Japão/China também apresentaram redução ao longo do período analisado, como já foi discutido na apresentação da Tabela 21. Da mesma forma que a ex-URSS, sua participação no total mundial também decresceu, concentrando menos de $10 \%$ do açúcar demandado no mercado internacional. O agregado Resto do Mundo, ao contrário, apresentou tendência crescente das quantidades importadas e da participação sobre o total ("import-share"), resultado já esperado desde que outros países, especialmente, da Ásia e da África vêm se destacando como grandes importadores, substituindo a participação perdida pela ex-URSS, Japão e China. Tal constatação ratifica as tendências sugeridas pelas taxas de crescimento estimadas (Tabela 20), que indicaram desaceleração nas quantidades importadas por esses três paises.

Tabela 22 - Participação dos países importadores selecionados nas importações mundiais $\left(\mathrm{m}_{\mathrm{i}}\right)$, Índice de Concentração Geográfica das importações e participação dos países exportadores no total comprado pelos importadores $\left(\mathrm{x}_{\mathrm{ij}}\right)$

\begin{tabular}{|c|c|c|c|c|c|c|}
\hline \multirow{2}{*}{$\begin{array}{c}\text { Destino } \\
\text { das } \\
\text { importações }\end{array}$} & \multirow{2}{*}{$\begin{array}{c}\text { Volume } \\
\text { importado - } \\
\text { Média anual } \\
\left(\mathrm{M}_{\mathrm{i}}\right) \\
\text { (Toneladas) }\end{array}$} & \multirow{2}{*}{$\begin{array}{c}\text { Participação } \\
\text { nas } \\
\text { Importações } \\
\text { Mundiais (m }\left(m_{i}\right) \\
(\%)\end{array}$} & \multirow{2}{*}{$\begin{array}{c}\text { Indice de } \\
\text { Concentração } \\
\text { Geográfica das } \\
\text { Importações }\end{array}$} & \multicolumn{3}{|c|}{$\begin{array}{l}\text { Origem das Importações } \\
\left(\mathrm{x}_{\mathrm{ij}}\right)\end{array}$} \\
\hline & & & & Brasil & Cuba & Resto Mundo \\
\hline \multicolumn{7}{|l|}{ Ex-URSS } \\
\hline $1982 / 84$ & 6.387 .779 & 22,39 & 67,07 & 11,84 & 59,44 & 28,72 \\
\hline $1985 / 89$ & 4.887 .576 & 17,58 & 77,51 & 7,48 & 75,17 & 17,35 \\
\hline $1990 / 94$ & 4.930 .172 & 17,20 & 69,36 & 3,66 & 57,03 & 39,31 \\
\hline \multicolumn{7}{|l|}{ Japão e China } \\
\hline $1982 / 84$ & 3.686 .345 & 12,92 & 75,04 & 1,47 & 29,59 & 68,94 \\
\hline $1985 / 89$ & 3.885 .062 & 13,97 & 74,75 & 1,84 & 29,51 & 68,65 \\
\hline 1990/94 & 2.859 .296 & 9,98 & 76,27 & 0 & 29,78 & 70,22 \\
\hline \multicolumn{7}{|c|}{ Resto do Mundo } \\
\hline $1982 / 84$ & 18.449 .951 & 64,68 & 78,73 & 10,55 & 12,43 & 77,02 \\
\hline $1985 / 89$ & 19.035 .838 & 68,45 & 82,09 & 8,13 & 10,92 & 80,95 \\
\hline 1990/94 & 20.869 .386 & 72,82 & 82,68 & 10,17 & 8,18 & 81,64 \\
\hline
\end{tabular}

Fonte: Elaborado pelo autor segundo dados da FAO Trade Yearbook, CACEX/DECEX e ISO (Internet). 
Observa-se pelos dados de origem das importações que o Brasil apresentou uma drástica redução da sua representatividade como exportador para a exURSS. No primeiro subperíodo atendia a $11,84 \%$ das necessidades de importação desse país, caindo para 3,66\% no subperíodo 1990/94. Esse dado contrasta com o aumento das exportações brasileiras de açúcar nesse último subperiodo, indicando que o Brasil expandiu seu comércio com novos mercados em detrimento dos tradicionais.

Verifica-se que Cuba atendeu a mais de $50 \%$ da demanda por açúcar importado pela ex-URSS durante o periodo analisado, sendo que no segundo subperíodo, quando os preços iniciaram sua fase ascendente (o preço internacional do açúcar atingiu a cotação mínima da década de 80, no ano de 1984), a participação de Cuba no total importado pela ex-URSS cresceu para $75,17 \%$. Contudo, a participação média para 1990/94 indica que houve uma perda discreta da participação cubana no atendimento a esse mercado importador.

Verifica-se que a participação de outros fornecedores de açúcar para a exURSS cresceu consideravelmente ao se comparar os subperíodos inicial e final. Provavelmente, o processo de abertura do bloco comunista contribuiu para que outros exportadores do produto conseguissem concorrer por um espaço nesse grande mercado consumidor. A independência política e econômica de algumas ex-repúblicas soviéticas também contribuiu para o surgimento de novos relacionamentos comerciais entre a região e outras nações.

As conclusões obtidas pela análise da Tabela 22 coincidem com aquelas já formuladas anteriormente na discussão da Tabela 21. Cuba tem sido responsável há vários anos por quase $30 \%$ das importações de açúcar pela China/Japão, enquanto o Brasil, no último subperíodo 1990/94, nem sequer constou como seu fornecedor. Nesse mesmo subperiodo, o Resto do Mundo apresentou uma discreta elevação na parcela que detém do mercado importador japonês e chinês, e como já foi comentado, essa diferença deve estar relacionada ao crescimento das exportações australianas e tailandesas com destino a esses importadores.

A participação dos exportadores selecionados no total importado pelo Resto do Mundo indica, mais uma vez, que, nos últimos anos, o Brasil tem recuperado 
seu papel como grande exportador de açúcar para o Resto do Mundo. Essa recuperação segue-se a um subperíodo (1985/89) de contração das exportações brasileiras de açúcar. Como nesse subperíodo os preços internacionais estavam em ascensão, provavelmente os determinantes dessa redução estiveram relacionados muito mais a fatores domésticos do que propriamente aos estímulos de preços no mercado externo.

Os resultados da Tabela 22 ainda ressaltam a perda de "market-share" de Cuba no mercado internacional de açúcar em comparação ao ganho pelo Resto do Mundo e Brasil no subperíodo mais recente da análise.

$\mathrm{O}$ Índice de Concentração Geográfica das Importações, calculado pela equação (19') indica uma redução discreta na diversificação dos países de origem do açúcar importado pela ex-URSS. No entanto, como já foi comentado, esses resultados devem ser analisados com cautela.

Para o caso do Japão e China, cuja concentração das exportações mostrou-se superior à soviética, também houve uma discreta redução no grau de diversificação. Aparentemente, essa redução é função do aumento da participação do Resto do Mundo, que, por sua vez, concentra a maioria dos países fornecedores.

O Grau de Preferência calculado pela expressão (11), apresentada no capítulo de Material e Métodos, proporciona uma aproximação do grau de aceitação de um importador pelo produto de determinada origem. Tais medidas, apresentadas na Tabela 23 são úteis para comparar a preferência do importador de açúcar por produtos originados de diferentes regiões.

A interpretação dos valores calculados é feita considerando-se que quanto mais fatores favoráveis (ou desfavoráveis) estiverem afetando as exportações, mais distante de 1 é o Grau de Preferência, uma vez que essa medida expressa a relação entre a exportação efetiva e a exportação esperada entre os pares de países. Se o valor calculado é superior a um $\left(\mathrm{P}_{\mathrm{ij}}>1\right)$ significa que as exportações do país de origem têm um grau elevado de aceitação no país consumidor, o qual pode ser resultante de acordos especiais, condições de pagamento diferenciado, facilidades de transporte e proximidade geográfica, tipo e qualidade do produto, políticas tarifárias, entre outros. Assim, esses fatores indicariam que existe preferência extra-preço relacionada à diferenciação do 
produto de uma dada origem pelo país importador. Quando $\mathrm{P}_{\mathrm{ij}}<1$, tem-se uma indicação de que esses fatores podem estar atuando de forma negativa sobre o relacionamento comercial do par de países analisado (não preferência extra-preço). Finalmente, valores iguais ou muito próximos da unidade sugerem que não existem desvios em função de fatores outros que não os preços.

Tabela 23 - Grau de Preferência $\left(\mathrm{P}_{\mathrm{ij}}\right)$ entre países selecionados, importadores e exportadores de açúcar. 1982-1994

\begin{tabular}{lccc}
\hline \multirow{2}{*}{ Exportador/Subperiodo } & \multicolumn{3}{c}{ Destino das Exportações } \\
\cline { 2 - 4 } & Ex-URSS & Japão e China & Resto do Mundo \\
\hline Brasil & 1,23 & 0,15 & 1,09 \\
$1982 / 84$ & 1,05 & 0,26 & 1,14 \\
$1985 / 89$ & 0,46 & 0,00 & 1,27 \\
$1990 / 94$ & & & \\
Cuba & 2,36 & 1,18 & 0,49 \\
$1982 / 84$ & 3,03 & 1,19 & 0,44 \\
$1985 / 89$ & 3,04 & 1,59 & 0,44 \\
$1990 / 94$ & & & 1,18 \\
Resto do Mundo & 0,44 & 1,06 & 1,19 \\
$1982 / 84$ & 0,26 & 1,01 & 1,12 \\
$1985 / 89$ & 0,54 & 0,96 & \\
$1990 / 94$ & & & \\
\hline
\end{tabular}

Fonte: Elaborado pelo autor segundo dados da FAO Trade Yearbook, CACEX/DECEX e ISO (Internet).

Konandreas \& Hurtado (1978) argumentam que essa medida permite selecionar os mercados nos quais mais esforços comerciais são necessários para assegurar uma maior participação. Além disso, a medida fornece um parâmetro para se comparar o grau de esforço requerido para expandir o "market-share" em diferentes mercados importadores. A Tabela 23 mostra que no subperíodo 1990/94, o mercado soviético era quase 1,91 vezes mais acessível para Cuba do que os mercados japonês/chinês, o que é 
dado pelo coeficiente da divisão entre os graus de preferência $(1,91=3,04 / 1,59)$. Esse tipo de constatação pode direcionar as políticas comerciais para um planejamento mais equilibrado, conforme os objetivos que o país exportador estabelece.

De modo geral, os valores não oscilaram muito para um mesmo país importador nos subperíodos analisados, exceção feita para o Brasil em relação à exURSS, cujo Grau de Preferência era maior que 1 em 1982/84, caindo para menos de 0,5 em 1990/94. A redução do grau de preferência sugere que ao longo desse periodo, as transações de açúcar entre os dois países foi prejudicada por fatores possivelmente associados ao processo de mudanças político-estruturais implementado na ex-URSS e à distância geográfica que beneficia outros exportadores mais próximos da região importadora.

A redução do Grau de Preferência pelo açúcar brasileiro ocorreu também no mercado do Japão/China, porém numa amplitude bem menor de variação do que no caso soviético. Para o Resto do Mundo o Grau de Preferência apresentou uma discreta elevação, refletindo as novas parcerias que o Brasil vem consolidando.

A formação do MERCOSUL e sua possível extensão a outros países da América do Sul, bem como as medidas recentes de redução na carga tributária sobre as exportações de commodities agrícolas, e, futuramente, as medidas que venham a ser implementadas visando reduzir os custos de comercialização e de transação, são fatores que devem tender a elevar o Grau de Preferência do Brasil com relação aos importadores mundiais de açúcar.

O Grau de Preferência calculado para Cuba no mercado soviético, nos três subperíodos, apresentou-se bem superior à unidade e com tendência crescente, indicando que possivelmente os acordos preferenciais relacionados à proximidade ideológica de seus governos favoreceram significativamente as quantidades transacionadas de açúcar. No mercado importador japonês/chinês o Grau de Preferência também foi maior que um e crescente, porém os valores mostram que há praticamente duas vezes mais facilidade (ou fatores favoráveis) para Cuba manter e/ou aumentar seu "market-share" no mercado soviético do que no mercado Japão/China. 
Situação bastante diversa é a da preferência do açúcar cubano pelo mercado importador Resto do Mundo, que se apresentou bem inferior a um para todo o período estudado. Neste caso, acredita-se que além dos fatores políticos e o embargo norte-americano que, de certa maneira, constituem-se em fatores que isolam Cuba do mercado mundial, o comprometimento da maior parte das exportações cubanas em acordos preferenciais com um grupo seleto de países fazem com que suas transações com as demais nações do mundo sejam praticamente marginais.

O crescimento das exportações de açúcar do Brasil, Cuba e Resto do Mundo pode ser desagregado em quatro efeitos, de acordo com o procedimento indicado pelas equações (14) a (18) apresentadas no sub-ítem 3.1.1.. A importância da análise desses efeitos não reside, necessariamente, na obtenção dos resultados em termos absolutos, mas sim na direção em que atuam sobre o saldo final das exportações. Por isso, os resultados apresentados neste trabalho serão expressos apenas pelos sinais encontrados para cada efeito, sem discutir sua magnitude.

Esse tipo de discussão está fundamentado na experiência dos trabalhos anteriores demonstrando que em modelos de " market-share" a escolha do nivel de agregação dos países e dos periodos de análise podem refletir-se em uma dispersão muito grande nos resultados em valores absolutos. Independentemente disso, acredita-se que os resultados apresentados na Tabela 24 foram coerentes com o que já foi discutido anteriormente.

Comparando-se o desempenho médio entre o primeiro subperíodo e o segundo, verifica-se que ocorreu uma retração do mercado importador mundial, resultando em um componente " tamanho de mercado" negativo sobre o crescimento das exportações para todos os paises. Os componentes "competitividade" e "distribuição do mercado importador" também foram desfavoráveis nesse intervalo para Brasil e Cuba. Tais resultados, no caso do Brasil, confirmam aqueles obtidos na análise de "marketshare" apresentada no sub-ítem anterior. O efeito "estrutura de preferências" foi o único que contribuiu favoravelmente para o crescimento das exportações de Cuba e do Brasil nesse mesmo período. 
Tabela 24 - Componentes do crescimento das exportações de açúcar dos países selecionados nos períodos 1982/84 - 1985/89 e 1985/89- 1990/94

\begin{tabular}{|c|c|c|c|c|}
\hline $\begin{array}{l}\text { Exportador } \\
\text { Período }\end{array}$ & $\begin{array}{l}\text { Efeito } \\
\text { Tamanho de } \\
\text { Mercado }\end{array}$ & $\begin{array}{c}\text { Efeito } \\
\text { Competitividade }\end{array}$ & $\begin{array}{c}\text { Efeito } \\
\text { Distribuição do } \\
\text { Mercado } \\
\text { Importador } \\
\end{array}$ & $\begin{array}{l}\text { Efeito Estrutura } \\
\text { de Preferências }\end{array}$ \\
\hline \multicolumn{5}{|l|}{ Brasil } \\
\hline $1982 / 84-1985 / 89$ & - & - & - & + \\
\hline 1985/89-1990/94 & + & + & + & - \\
\hline \multicolumn{5}{|l|}{ Cuba } \\
\hline 1982/84 -1985/89 & - & - & - & + \\
\hline $1985 / 89-1990 / 94$ & + & - & - & + \\
\hline \multicolumn{5}{|l|}{ Resto do Mundo } \\
\hline $1982 / 84-1985 / 89$ & - & + & + & - \\
\hline $1985 / 89-1990 / 94$ & + & + & + & - \\
\hline
\end{tabular}

Fonte: Elaborado pelo autor segundo dados da FAO Trade Yearbook, CACEX/DECEX e ISO (Internet)

* Pela convenção adotada: sinal (+) significa efeito favorável ao crescimento das exportações, sinal (-) efeito desfavorável ao crescimento das exportações.

É interessante observar que, entre o primeiro e segundo subperíodos, o Resto do Mundo apresentou efeitos "competitividade", "distribuição do mercado importador" e "estrutura de preferências" com sinais opostos ao de Brasil e Cuba, confirmando que deve haver uma complementariedade, de forma que se os dois exportadores perderam competitividade no mercado internacional, necessariamente outros países devem ter ganho competitividade. O mesmo raciocínio pode ser utilizado para analisar o sinal negativo do efeito "estrutura de preferência" sobre o crescimento das exportações do Resto do Mundo.

A Tabela 24 evidencia que o crescimento das exportações brasileiras entre os subperíodos 1985/89 e 1990/94 apresentou um componente "tamanho de mercado" positivo, devido à expansão do mercado importador neste período. Reforçando os resultados apresentados na Tabela 21, há indicação de que o Brasil recuperou parte do 
"export-share" que detinha no início do período analisado (1982/84), devido a sua maior competitividade no mercado. Os ganhos em competitividade podem ser decorrentes de: investimentos aplicados no desenvolvimento tecnológico do setor ao longo das últimas décadas, elevando a produtividade, reduzindo custos; e sobretudo, da maior flexibilidade na distribuição das cotas de exportação acompanhada da menor rigidez na sua fiscalização.

O componente "distribuição do mercado importador" também contribuiu favoravelmente para o crescimento das exportações açucareiras do Brasil entre o período 1984/89 e 1990/94 o que pode ser parcialmente explicado pelo aumento do número de participantes nas transações de açúcar do Brasil e à redução da participação de países como a ex-URSS, EUA e Iraque, cujas taxas de crescimento das importações foram negativas (Tabela 20).

Verificou-se que o efeito "estrutura de preferências" foi o único que não contribuiu para aumentar as exportações brasileiras de açúcar nesta segunda fase. Possivelmente, a redução das importações norte-americanas seja um dos fatores responsáveis por esse efeito, uma vez que os Estados Unidos, desde o final da década de 70 até meados da década de 80 , constou como o maior importador do produto brasileiro em vários anos desse intervalo. A análise de "market-share" apresentada não incluiu os dois últimos anos, 1995 e 1996, nos quais os volumes autorizados pelos EUA para importação de açúcar se recuperaram.

A decomposição do crescimento das exportações de Cuba para esse segundo intervalo, apresentou além do componente "tamanho de mercado" positivo, a manutenção da tendência de perda de competitividade no mercado internacional de açúcar. É possível relacionar parte dessa perda aos problemas climáticos que assolaram a ilha recentemente, reduzindo sua produção ( na safra 1991/92 produziu 7,03 milhões de toneladas contra 4,28 na safra 1992/93, segundo dados da International Sugar Organization).

Alguns fatores que podem justificar esses resultados foram discutidos na Sugar Y Azucar (1996a). A crise política nos países comunistas, restringindo o apoio financeiro dos mesmos para Cuba, contribuiu para esse resultado desfavorável, já que a 
carência de petróleo e fertilizantes provocaram uma redução no nível de produtividade das lavouras desse país. A própria estrutura de produção agrícola cubana foi modificada pela substituição das grandes propriedades estatais por milhares de cooperativas que não foram capazes de manter os níveis de produtividade e produção anteriores ao novo sistema.

Além disso, segundo os resultados deste trabalho, pelo segundo período consecutivo, Cuba apresentou um efeito "distribuição de mercado" negativo, o que já era esperado uma vez que a composição dos países com os quais comercializa açúcar é rígida e predominantemente composta por países de regime comunista, os quais devido às instabilidades políticas passaram a contrair suas importações. Num segundo estágio desse processo, a desestruturação política pode até permitir a maior flexibilidade na escolha de fornecedores, abrindo esses mercados para outros exportadores não tradicionais.

Contudo, o efeito "estrutura de preferências" na evolução das exportações de Cuba permaneceu positivo também no segundo intervalo, mesmo porque a composição do seu mercado comprador não se alterou significativamente, mantendo-se as participações dos tradicionais parceiros comerciais, condicionados a acordos especiais.

A Tabela 24 mostra que o crescimento das exportações de açúcar do Resto do Mundo, no segundo período analisado, apresentou os efeitos na mesma direção que o Brasil, sugerindo que esse País vem acompanhando a tendência geral do mercado internacional. A mesma observação não pode ser estendida para o caso de Cuba.

Pode-se inferir que os resultados discutidos acima refletem de certo modo o aumento da concorrência dentro do mercado mundial de açúcar. Brasil e Cuba dividem seus papéis de grandes produtores e exportadores com novos participantes no mercado. Por sua vez, a composição do mercado importador também vem se alterando, de forma que EUA, ex-URSS, China, Japão e União Européia já não são mais os únicos e potenciais escoadouros do açúcar produzido pelos países em desenvolvimento.

O Brasil perdeu participação no mercado soviético e norte-americano ${ }^{34}$, dois

\footnotetext{
${ }^{34}$ As exportações brasileiras respondiam em média por $17,36 \%$ das importaç̃es totais de açúcar dos EUA no subperíodo 1979/84; reduziu-se para $8,20 \%$ no subperiodo $1985 / 89$; recuperando-se, parcialmente, até alcançar a média de $11,82 \%$ no subperíodo $1990 / 94$.
} 
grandes compradores do produto. Além disso, não tem tradição de comercializar quantidades significativas e estáveis com os demais grandes importadores mundiais como a China, Japão, Coréia, Canadá, Reino Unido e a própria União Européia como um todo. No entanto, o País vem incrementando e diferenciando suas exportações (por países e por tipo de açúcar) para regiões na África e Ásia, onde a renda per capita ainda é baixa, passivel de acréscimos que, certamente, resultariam no aumento do consumo de produtos básicos e de produtos industrializados que contêm o açúcar.

Atualmente, os maiores compradores do Brasil têm sido países em desenvolvimento da África (Nigéria, Marrocos, Egito, Argélia, Jordânia) e da Ásia (Jordânia, Irã, Sri-Lanka), mas é necessário organizar estratégias para assegurar esses mercados e competir em outros cujas taxas de crescimento indiquem potencial futuro como consumidores importantes, como é o caso dos países do sudeste asiático. O planejamento é fundamental, dado que próximos a esses mercados importadores em crescimento localizam-se concorrentes importantes no mercado de exportação de açúcar, como a Austrália e a Tailândia.

Outra evidência levantada pelos resultados acima é que o Brasil, aparentemente, não se apropriou da grande parcela perdida por Cuba nos últimos anos como alguns analistas vem afirmando, principalmente nos seus grandes mercados importadores, os quais foram analisados na presente dissertação, e que compreendem aproximadamente $68 \%$ da demanda externa pelo açúcar cubano. Provavelmente, a União Européia, Austrália e Tailândia foram responsáveis por atender à brecha na demanda de açúcar provocada pela retração na safra e nas exportações cubanas.

\subsection{Modelo de elasticidade de substituição}

Os paises exportadores de açúcar para os quais se procedeu à estimação de coeficientes da elasticidade de substituição foram selecionados em função de sua participação média no mercado de exportação açucareira, no periodo 1979 a 1994 (Tabela 20). Essas elasticidades de substituição estimadas podem complementar as conclusões da análise de "market-share", melhor caracterizando o mercado exportador de 
açúcar. Finalmente, esses resultados podem contribuir na avaliação do grau de competitividade entre exportadores e da diferenciação (ou homogeneidade) do produto sob a perspectiva do mercado mundial importador.

As estimativas de elasticidade de substituição entre o Brasil e os paises exportadores de açúcar selecionados são apresentadas na Tabela 25. Os coeficientes foram estimados conforme a eq. (25), utilizando o método de mínimos quadrados ordinários, e procedendo-se ao método de filtragem de Cochrane-Orcutt, quando constatada a presença de autocorrelação dos resíduos.

A inclusão de uma variável tendência na equação de estimação, em geral, não alterou muito os resultados. O procedimento de incluir a variável independente defasada, relação de preços de exportação dos países, gerou resultados ainda menos significativos $^{35}$. Os resultados apresentados na Tabela 25 são aqueles obtidos pelo melhor ajustamento para o modelo dentre essas alternativas mencionadas.

Modelos incluindo a variável dependente defasada como variável explicativa foram testados conforme a eq. (26), e, em geral, seus resultados confirmaram aqueles obtidos para os modelos estimados pela eq. (25). Mesmo nos casos em que os coeficientes obtidos para a eq. (25) não foram significativos, a utilização da variável endógena defasada de um periodo não melhorou os resultados. Não foram utilizadas regressões com mais de uma defasagem dada a restrição no número de observações disponíveis.

A adoção de variáveis endógenas defasadas como variáveis explicativas foi utilizada por Fontes et al.(1989) no estudo do comércio exterior de grãos dos Estados Unidos, sendo justificada de maneira "ad hoc" pelos autores pelo fato de que as importações são normalmente controladas pelo governo, e, muitas vezes, sujeitas a contratos de longo prazo, gerando certa rigidez nos ajustes das quantidades transacionadas no mercado internacional.

\footnotetext{
${ }^{35}$ Esta variável "lagged" foi incluída considerando-se que pode haver uma defasagem no ajuste das quantidades exportadas em relação aos preços relativos, dado que a oferta de açúcar por país exportador, individual, pode ser considerada com certo grau de inelasticidade. Isso se deve ao fato da cana, matériaprima da qual se origina a maior parte do açúcar comercializado mundialmente, constituir-se numa planta semi-perene.
} 
Tabela 25 - Estimativas de elasticidade de substituição ${ }^{1}$. Valor para o teste " $t$ " de Student entre parênteses e Durbin-Watson. 1979-1994

\begin{tabular}{|c|c|c|c|}
\hline \multirow{2}{*}{$\begin{array}{l}\text { Brasil/Outro país } \\
\text { exportador }\end{array}$} & \multicolumn{3}{|c|}{ Tipo de Açúcar } \\
\hline & Açúcar total & $\begin{array}{c}\text { Açúcar Bruto } \\
\text { (Demerara + Cristal) }\end{array}$ & Açúcar Refinado \\
\hline \multirow[t]{3}{*}{ Brasil/Africa do Sul } & $-2,31^{* 2}$ & $-1,99^{2}$ & $-1,06$ \\
\hline & $(-1,82)$ & $(-1,49)$ & $(-0,41)$ \\
\hline & $\mathrm{DW}=1,42$ & $\mathrm{DW}=1,48$ & $\mathrm{DW}=0,48$ \\
\hline \multirow[t]{3}{*}{ Brasil/Cuba } & $0.16^{2}$ & $0,27^{2}$ & $0,18^{2}$ \\
\hline & $(0,50)$ & $(0,74)$ & $(0,44)$ \\
\hline & $\mathrm{DW}=1,09$ & $\mathrm{DW}=1,24$ & $\mathrm{DW}=1,52$ \\
\hline Brasil/República & $-0,08^{2}$ & $-0,24$ & $1,98^{2}$ \\
\hline \multirow[t]{2}{*}{ Dominicana } & $(-0,19)$ & $(-0,391)$ & $(1,69)$ \\
\hline & $\mathrm{DW}=1,91$ & $\mathrm{DW}=0,54$ & $\mathrm{DW}=0.76$ \\
\hline \multirow[t]{3}{*}{ Brasil/Filipinas } & $-0,97^{* 2}$ & $-0,51^{2}$ & $-3,0^{* 2}$ \\
\hline & $(-2,36)$ & $(-1,24)$ & $(-4,33)$ \\
\hline & $\mathrm{DW}=2,18$ & $\mathrm{DW}=2,14$ & $\mathrm{DW}=1,78$ \\
\hline \multirow[t]{3}{*}{ Brasil/Tailândia } & $1.21^{2}$ & $1,88^{* 2}$ & $2,071^{3}$ \\
\hline & $(1,55)$ & $(2,25)$ & $(0,815)^{2}$ \\
\hline & $\mathrm{DW}=1,92$ & $\mathrm{DW}=1,92$ & $\mathrm{DW}=2,22$ \\
\hline \multirow[t]{3}{*}{ Brasil/França } & $0,14^{2}$ & $-1,32^{*}$ & $-0,17^{2}$ \\
\hline & $(0,37)$ & $(-3,16)$ & $(-0,39)$ \\
\hline & $\mathrm{DW}=1,39$ & $\mathrm{DW}=1,22$ & $\mathrm{DW}=1,29$ \\
\hline \multirow[t]{3}{*}{ Brasil/Alemanha } & $-0,18^{2}$ & $1,07^{*}$ & $-1,09^{*}$ \\
\hline & $(-0,95)$ & $(1,88)$ & $(-2,76)$ \\
\hline & $\mathrm{DW}=1,42$ & $\mathrm{DW}=1,34$ & $\mathrm{DW}=0,94$ \\
\hline \multirow[t]{3}{*}{ Brasil/Austrália } & -0.49 & $0,23^{2}$ & $-0,73 * 2$ \\
\hline & $(-1,379)$ & $(0,81)$ & $(-1,83)$ \\
\hline & $\mathrm{DW}=0,94$ & $\mathrm{DW}=1,62$ & $\mathrm{DW}=1,90$ \\
\hline \multicolumn{4}{|c|}{$\begin{array}{l}\text { Fonte: Elaborado pelo autor segundo dados da FAO Trade Yearbook. } \\
{ }^{1} \text { Os coeficientes de determinação das regressões estimadas foram todos superiores a } 0,80 \text {, significando } \\
\text { que as variáveis utilizadas como explicativas são responsáveis no mínimo por } 80 \% \text { das variações na } \\
\text { variável dependente. Logo, indica que o ajustamento do modelo foi satisfatório. } \\
{ }^{2} \text { Coeficientes corrigidos para autocorrelação dos resíduos pelo método de Cochrane-Orcutt. } \\
{ }^{3} \text { O coeficiente de determinação encontrado neste caso foi muito baixo, sugerindo que outras variáveis } \\
\text { podem estar influenciando a relação entre quantidades exportadas. } \\
\text { * Significativo a } 10 \% \text {. }\end{array}$} \\
\hline
\end{tabular}


Como o mercado internacional de açúcar é bastante regulamentado nos paises exportadores e também nos importadores, além da existência de acordos especiais como o da União Européia com suas ex-colônias do grupo ACP (África, Caribe e Pacífico), considerou-se a possibilidade de que a comercialização dessa commodity também pode estar sujeita à rigidez de mercado.

Constatou-se, ainda, que alguns valores de elasticidade de substituição não se mostraram significativos quando estimados para os dados de exportação de açúcar total (em equivalente demerara, somados os três tipos de açúcar: demerara, cristal e refinado). Isso ocorre porque alguns exportadores destacam-se na produção e exportação de um tipo de açúcar e não necessariamente em todos os outros. Além disso, cada tipo de açúcar pode apresentar um mercado específico e diferenciado.

África do Sul

O coeficiente de elasticidade de substituição obtido para Brasil/África do Sul é estatisticamente significativo a $10 \%$ no caso das exportações de açúcar total, indicando que a uma redução de $1 \%$ nos preços relativos Brasil/África do Sul corresponde um aumento de, aproximadamente, 2,31\% na quantidade exportada pelo Brasil em relação à sul-africana. Verifica-se na Tabela 26 que o modelo utilizando como variável defasada as quantidades relativas confirmou a elasticidade de substituição elevada entre Brasil/África do Sul $(-3,13)$. Esse resultado sugere que há uma relação de competitividade entre os dois exportadores no mercado mundial de açúcar. Além disso, 0 coeficiente da variável defasada foi estatisticamente significativo, sendo estimado em 0,74 , indicando, portanto, que as quantidades exportadas no ano anterior têm certa influência na determinação das quantidades comercializadas no período contemporâneo.

Apesar da hipótese de nulidade dos coeficientes da elasticidade de substituição relativa a Brasil/África do Sul não ser rejeitada para o açúcar bruto e para o refinado, as elasticidades encontradas nesses casos foram negativas e superiores a um (Tabela 25). A inclusão da variável defasada gerou um coeficiente significativo para o açúcar bruto de $-2,76$ confirmando a existência da substituição entre os dois fornecedores, assim como um efeito significativo da variável defasada na determinação das exportações. 
Tabela 26 - Estimativas de elasticidade de substituição para açúcar entre o Brasil e os principais exportadores mundiais e coeficientes da variável dependente defasada de um período $(\gamma)$. Valor para o teste " $t$ " de Student entre parênteses. 1979-1994

\begin{tabular}{|c|c|c|c|}
\hline Exportadores & Açúcar total & $\begin{array}{c}\text { Açúcar Bruto } \\
\text { (Demerara + Cristal) }\end{array}$ & Açúcar Refinado \\
\hline \multirow[t]{3}{*}{ Brasil/África do Sul } & $-3,13^{*}$ & $-2,76^{*}$ & 0,16 \\
\hline & $(-2.59)$ & $(-2,30)$ & $(0,94)$ \\
\hline & $\gamma=0,74^{*}$ & $\gamma=0,81^{*}$ & $\gamma=1.85$ \\
\hline \multirow[t]{3}{*}{ Brasil/Cuba } & $0,34^{*}$ & $0,39 *$ & 0,17 \\
\hline & $(1,97)$ & $(2,01)$ & $(0,14)$ \\
\hline & $\gamma=0,96^{*}$ & $\gamma=0,97^{*}$ & $\gamma=1,53^{*}$ \\
\hline Brasil/República & 0,03 & 0,43 & $1,86^{\top}$ \\
\hline \multirow[t]{2}{*}{ Dominicana } & $(-0,078)$ & $(0,91)$ & $(1,29)$ \\
\hline & $\gamma=0,46$ & $\gamma=0,73^{*}$ & $\gamma=0,76^{*}$ \\
\hline \multirow[t]{3}{*}{ Brasil/Filipinas } & $-0,81^{*}$ & $-0,39$ & $-1,83^{*}$ \\
\hline & $(-2,60)$ & $(-1,19)$ & $(-2,96)$ \\
\hline & $\gamma=0,23$ & $\gamma=0,27$ & $\gamma=0,12$ \\
\hline \multirow[t]{3}{*}{ Brasil/Tailândia } & 1,59 & $2,14^{*}$ & 3,91 \\
\hline & $(1,73)$ & $(2,25)$ & $(1,18)$ \\
\hline & $\gamma=0,43$ & $\gamma=0,53 *$ & $\gamma=-0,10$ \\
\hline \multirow[t]{3}{*}{ Brasil/França } & $0,90^{* 1}$ & 0,28 & 0,04 \\
\hline & $(2,65)$ & $(1,53)$ & $(0,07)$ \\
\hline & $\gamma=0,84^{*}$ & $y=1,09^{*}$ & $\gamma=0,60^{*}$ \\
\hline \multirow[t]{3}{*}{ Brasil/Alemanha } & $0,17^{\top}$ & 1,48 & $-1,14^{* 1}$ \\
\hline & $(0,68)$ & $(1,58)$ & $(-3,65)$ \\
\hline & $\gamma=0,68^{*}$ & $\gamma=0,03$ & $\gamma=0,11$ \\
\hline \multirow[t]{3}{*}{ Brasil/Austrália } & $-0,11$ & $0,39^{1}$ & $-0,83$ \\
\hline & $(-0,29)$ & $(0,94)$ & $(-1,72)$ \\
\hline & $\gamma=0,60^{*}$ & $\gamma=0,86^{*}$ & $\gamma=0,60^{*}$ \\
\hline
\end{tabular}

Fonte: Elaborado pelo autor segundo dados da FAO Trade Yearbook.

${ }^{1} \mathrm{O}$ teste $\mathrm{Q}$ (Ljung - Box) foi significativo a $10 \%$, indicando a presença de autocorrelação dos resíduos. Portanto, os coeficientes correspondentes devem ser analisados com cautela.

* Significativo a $10 \%$. 
É interessante lembrar que o volume de açúcar exportado pela África do Sul reduziu-se nos últimos quatro anos analisados, sendo que a taxa de crescimento dessas exportações para o período analisado foi de $-5,98 \%$ (Tabela 20). O Brasil, ao contrário, tem aumentado seu "market-share" nesse período. Tem-se, portanto, uma indicação de que o Brasil pode ter assimilado parte do mercado perdido pela África do Sul, o que, no entanto, só pode ser confirmado pela observação dos dados desagregados de exportações por destino da África do Sul.

É importante lembrar que o açúcar bruto (demerara e cristal) é o principal tipo exportado pela África do Sul, cujo custo de produção caracteriza-se como um dos mais baixos do mundo (Anexo I), fato que o mantém ainda como um concorrente potencial importante para o Brasil no abastecimento de países importadores que, por uma questão de logística, beneficiam as exportações sul-africanas.

$\underline{\text { Cuba }}$

Os coeficientes de elasticidade de substituição entre Cuba e Brasil (Tabela 25) não se mostraram significativos estatisticamente para nenhum dos casos examinados. Verificou-se a existência de autocorrelação positiva dos resíduos e mesmo após a filtragem dos dados foram encontrados coeficientes positivos $e$ inferiores a um (estatisticamente não significativos). Esses valores encontrados não permitem concluir a respeito da substituição (ou diferenciação) do açúcar originado desses dois países exportadores, em função de preços relativos.

Os coeficientes apresentados na Tabela 26 são todos positivos e inferiores a um para Brasil/Cuba, sendo significativos no caso do açúcar total e do bruto, não havendo, contudo, uma explicação empírica para tais estimativas. Evidencia-se ainda que os coeficientes para a variável defasada são todos significativos e próximos da unidade, o que sugere rigidez na determinação das quantidades relativas exportadas.

Tais resultados podem ser relacionados com o isolamento parcial de Cuba da competição existente no mercado internacional de açúcar. Os mercados atendidos por esse pais, assunto que já foi explorado pela análise de "market-share", são tradicionais e bem consolidados através de acordos preferenciais que têm vigorado há vários anos. 
Parece razoável admitir, portanto, que a relação de preços de exportação entre Brasil e Cuba não deva alterar a quantidade relativa exportada por esses paises, em função desta rigidez institucional nas transações comerciais de Cuba.

Cuba, como a África do Sul, destaca-se na produção e exportação de açúcar bruto, sendo que no período analisado verificou-se uma taxa de crescimento negativo de suas exportações. Os coeficientes estimados para elasticidade de substituição também não indicaram relação de substituição via preços relativos, do açúcar de Cuba pelo do Brasil, de forma semelhante ao que foi observado com relação aos resultados da análise de "market-share", os quais também não permitiram afirmar que o Brasil substituiu Cuba na parcela significativa que esse pais perdeu no mercado mundial.

\section{República Dominicana}

Não se verificaram estimativas de elasticidade de substituição significativas entre Brasil e República Dominicana tanto para o açúcar total como para o açúcar bruto e refinado nos dois modelos analisados (Tabelas 25 e 26).

A República Dominicana foi outro país que teve seu volume exportado de açúcar reduzido significativamente desde o final da década de 70. Apresentou a taxa de crescimento negativa mais elevada dentre os exportadores avaliados $(-8,16 \%)$. O pais detém a maior cota de exportação no mercado preferencial norte-americano e provavelmente essa queda na sua participação como exportador mundial seja parcialmente explicada pela redução das cotas norte-americanas de importação de açúcar ao longo do periodo.

No ano de 1996, os Estados Unidos aumentaram suas cotas de importação de açúcar, o que favoreceu não só à República Dominicana, mas também ao Brasil. Para o ano fiscal de 1997 foram estabelecidas 2,3 milhões de toneladas como volume total de cota a serem importadas, livre de tarifas, sendo que as maiores parcelas desse total foram destinadas à: República Dominicana (285.588 ton), Brasil (235.286 ton), Filipinas (219.059 ton) e Austrália (134.681 ton), segundo dados divulgados pela Sugar Y Azucar $(1996 c)$. 
O País não se destaca na comercialização de açúcar refinado, tendo praticamente zerado tais exportações nos últimos três anos compreendidos pela análise, coincidindo com o período em que o Brasil aumentou as exportações de açúcar refinado. Filipinas

As elasticidades estimadas para Brasil e Filipinas, apresentadas na Tabela 25 , indicam a existência de um certo grau de substituição entre os produtos originados dos dois países, dadas as variações nos preços relativos, ceteris paribus. A cada $1 \%$ de redução na relação de preços Brasil/Filipinas para o açúcar total, corresponde um aumento de $0,97 \%$ na quantidade exportada pelo Brasil em relação à exportada pelas Filipinas. A competição entre os dois paises é bem maior para o açúcar refinado, sendo que a elasticidade de substituição estimada indica que a cada $1 \%$ de redução nos preços relativos pode ocorrer um aumento de $3,0 \%$ na quantidade exportada pelo Brasil em relação à exportada pelas Filipinas.

Os resultados apresentados na Tabela 26 confirmam o que foi discutido acima, porém, o coeficiente encontrado para o açúcar refinado, apesar de indicar relação de substituição, é relativamente menor $(-1,83)$ neste caso. $O$ coeficiente da variável defasada não se mostrou significativo a $10 \%$.

Os dados utilizados neste trabalho mostram que as exportações de açúcar das Filipinas foram drasticamente reduzidas, passando de pouco mais de um milhão em 1979, para cem mil toneladas anuais em 1994. Essa redução pode ser explicada, segundo informações divulgadas em SUGAR development (1995), pelos problemas climáticos que assolaram esse país (seca e enchentes), provocando uma queda de $11,29 \%$ na safra de cana-de-açúcar. Tal situação modificou o status do país de exportador para importador no mercado internacional. Na safra 1994/95, as Filipinas compraram açúcar da Tailândia e da Austrália.

A perda de "market-share" pelas Filipinas no mercado internacional de açúcar ocorreu ao longo do período estudado, havendo a possibilidade do Brasil ter assimilado parcela do mesmo. Tal suposição só poderia ser testada, no entanto, se houvesse a disponibilidade dos dados desagregados quanto ao destino do açúcar exportado pelas Filipinas. 


\section{Tailândia}

Verificaram-se estimativas positivas da elasticidade de substituição entre Brasil e Tailândia para os três tipos de açúcar analisados (Tabelas 25 e 26). Contudo, o coeficiente só mostrou-se significativo para o caso do açúcar bruto (cristal + demerara).

$O$ coeficiente de determinação muito baixo encontrado na estimação dos coeficientes de Brasil/Tailândia, sugere que o ajustamento do modelo não foi adequado, indicando a existência de outras variáveis não incluídas no modelo e que devem estar afetando a relação das quantidades exportadas.

Uma hipótese possível para explicar os coeficientes encontrados é que Brasil e Tailândia não atendem os mesmos nichos de mercados. É provável que determinantes relacionados à localização geográfica, lingua e fatores psicológicos ou até mesmo a qualidade do produto, sejam responsáveis pela escolha do mercado importador. Como se observa no Anexo I, os dois exportadores detém custos bastante baixos de produção, sendo que seus preços de exportação apresentam o coeficiente de correlação relativamente elevado $(0,86)$, indicando que apresentam a mesma tendência de variação.

A evolução das exportações de açúcar da Tailândia, assim como a do Brasil, indicou um crescimento positivo, embora esse aumento tenha sido gradativo ao longo de todo o periodo analisado. No caso do Brasil, no entanto, esse fenômeno passou a ocorrer a partir dos últimos cinco anos. A Tailândia apresentou um acréscimo na comercialização também do açúcar refinado.

\section{França}

A elasticidade de substituição entre Brasil e França para o açúcar bruto, estimada em -1,32 é estatisticamente significativa a $10 \%$, indicando que há um elevado grau de competição via preços entre esses dois países, ceteris paribus. Para cada $1 \%$ de variação na relação de preços Brasil/França, tem-se uma variação em sentido oposto de $1,32 \%$ na quantidade relativa exportada pelos mesmos. Portanto, os produtos originados desses dois países são concorrentes no mercado mundial. Os demais coeficientes apresentados não foram significativos estatisticamente (Tabela 25). No modelo com variável defasada foi encontrado coeficiente positivo para a elasticidade de substituição 
no caso do açúcar total (Tabela 26), mais uma vez um resultado dificil de ser interpretado tanto teórica quanto empiricamente.

Os coeficientes da variável defasada são todos significativos, indicando que há rigidez na determinação das quantidades exportadas. Tal resultado é condizente com o padrão de produção e comercialização de açúcar caracterizado pela existência de cotas e excedentes pré-determinados, impostos pela União Européia. É notório que o açúcar é uma das commodities mais regulamentadas no comércio internacional, existindo acordos preferenciais de médio e longo prazos da UE com suas ex-colônias, o que contribui para conferir essa rigidez ao mercado.

A taxa de crescimento das exportações de açúcar da França foi muito próxima de zero, sendo que desde o início dos anos 80 o pais vem reduzindo suas exportações de açúcar bruto, em contrapartida a um ligeiro crescimento nas exportações de refinado.

O Brasil tem vantagens em relação à França por apresentar custos inferiores de produção (Anexo I), embora o setor exportador nacional se defronte com dificuldades institucionais internas, impostos e fretes mal dimensionados, ineficiência do sistema portuário, além dos problemas de política cambial. Por sua vez, a França se beneficia dos acordos preferenciais e da sustentação econômica que a União Européia promove sobre seus excedentes agrícolas, através de subsídios, para que se tornem assimiláveis pelo mercado mundial. A França, além de destacar-se na exportação de refinado e em menor grau de açúcar bruto, consiste também em importadora desse último, o qual geralmente é destinado ao refino e à reexportação.

\section{Alemanha}

A elasticidade de substituição estimada para o açúcar total entre Brasil e Alemanha não foi significativa. No caso do açúcar bruto, o coeficiente encontrado foi significativo, porém, de sinal contrário ao esperado. A limitação no número de observações pode ser responsável pelos resultados atípicos. Outra hipótese é a inexistência de relação entre os preços e quantidades exportadas pelos dois países, seja porque cada exportador atua em mercados distintos, seja pela existência dos acordos 
prefenciais, tarifas e outros mecanismos que isolam os exportadores das alterações no mercado mundial. De qualquer forma, é possível que tal sinal esteja relacionado à baixa representatividade da Alemanha como exportador de açúcar demerara e cristal.

No caso do coeficiente de elasticidade de substituição obtido para o açúcar refinado, as expectativas da competição entre os dois exportadores foram confirmadas. A elasticidade de substituição estimada é negativa e significativa estatisticamente, indicando que um aumento de $1 \%$ na relação de preços Brasil/Alemanha leva à variação negativa de $1,07 \%$ na quantidade de açúcar brasileiro exportada em relação à quantidade da Alemanha. Portanto, podem ser considerados produtos substitutos no mercado mundial, concorrendo em preços pelo "market-share". O ajustamento do modelo com variável defasada levou praticamente às mesmas conclusões (Tabela 26).

A Alemanha, juntamente com a França, compreendem os dois grandes exportadores de açúcar dentro da União Européia. Apesar das políticas comuns estabelecidas pela União Européia, a evolução das exportações de açúcar da Alemanha mostrou um crescimento bem superior ao da França, estimando-se uma taxa de crescimento positiva de $3,19 \%$. Destaca-se na exportação de refinado, tendo mantido as exportações de açúcar bruto num patamar praticamente constante e irrelevante.

Austrália

Os coeficientes obtidos para a elasticidade de substituição entre Brasil e Austrália não indicam que exista relação de substituição entre o açúcar proveniente dos dois países. Ao contrário, há indícios de que ocorre uma certa diferenciação dos produtos por parte do mercado importador, principalmente no caso do açúcar refinado, cuja estimativa negativa foi significativa estatisticamente e de valor menor que um. $O$ coeficiente sugere que a um aumento de $1 \%$ no preço relativo Brasil/Austrália, corresponde uma redução menos que proporcional de $0,73 \%$ na quantidade exportada pelo Brasil. Isso indica a presença de fatores extra-preço, como qualidade, facilidades de crédito e de transporte, entre outros, que influenciam na escolha do país importador. 
Os coeficientes obtidos no modelo com variáveis defasadas não foram significativos para a variável preços relativos, porém indicaram que existe uma relação de dependência entre as quantidades relativas defasadas $\mathrm{e}$ as quantidades relativas contemporâneas de exportação.

A taxa de crescimento calculada para as exportações totais de açúcar da Austrália foi de $2,22 \%$ (Tabela 20). Tal resultado é corroborado pelos dados apresentados em SUGAR developments (1995), segundo os quais a Austrália expandiu em $30 \%$ sua área cultivada com cana, em relação às estatísticas de 1989. Ainda, segundo a mesma fonte, as exportações desse país com destino à região sudeste da Ásia vem crescendo, expandindo-se nas Filipinas, Japão, Malásia, Coréia e China, mercados nos quais apresenta a vantagem da proximidade geográfica. A Queensland Sugar Corporation, que produz $95 \%$ do açúcar bruto australiano, tem praticamente $70 \%$ de suas exportações asseguradas pela demanda da Ásia.

A Austrália, embora sem tradição na exportação do açúcar refinado, vem apresentando crescimento da mesma nos últimos anos, provavelmente em resposta à maior demanda desse tipo de açúcar pelos países em desenvolvimento da Ásia. Constatou-se um crescimento discreto nas quantidades comercializadas de açúcar bruto, sendo que seu custo de produção baixo assegura sua competitividade no mercado internacional.

Como último comentário é importante ressaltar que o número limitado de observações utilizadas e a falta de dados de exportação por país de origem, por país de destino, são fatores que podem ter contribuído para os valores atípicos resultantes no modelo da elasticidade de substituição testado neste trabalho.

Além disso, é importante lembrar que a teoria que fundamenta o conceito da elasticidade de substituição prevê que, quando as pressuposições de simetria não se verificam em condições empíricas, é possível obter coeficientes positivos $(b>0)$, sugerindo uma relação de complementariedade entre os produtos de dois exportadores. Tal situação pode ser considerada uma possível explicação para os coeficientes positivos e significativos estimados para Brasil/Tailândia e Brasil/Cuba. Nesse contexto, os produtos seriam diferenciados, a ponto de não atuarem no mesmo nicho de mercado. 


\section{CONCLUSÕES}

Os resultados obtidos no presente trabalho permitiram atender aos objetivos propostos inicialmente e estabelecer algumas perspectivas para o mercado exportador de açúcar do Brasil nos próximos anos. Tais resultados podem contribuir para a formulação de estratégias comerciais para o setor exportador açucareiro.

A análise de "market-share" para o Brasil, no período entre 1979 e 1994, mostrou que o País vem crescendo em participação no mercado de açúcar, especificamente desde 1990, não só devido ao crescimento do mercado mundial mas também ao incremento na sua competitividade. Esses ganhos em competitividade são decorrentes, provavelmente, dos investimentos que foram feitos no setor sucroalcooleiro em anos passados, gerando tecnologia suficiente para reduzir os custos de produção a um nivel considerado dos mais baixos do mundo. Além disso, contribuíram as recentes medidas políticas implementadas e voltadas à desregulamentação do setor que proporcionaram uma maior flexibilidade na determinação das cotas de produção e de exportação, a possibilidade de importar álcool e a liberação dos preços do setor.

Verifica-se que, além da disponibilidade de açúcar para comercialização e da maior flexibilidade nas políticas que regem o setor, outros fatores contribuíram para a alteração dos padrões de exportação dessa commodity pelo Brasil. As mudanças no perfil do mercado importador (na composição e participação dos paises) e na proporção dos tipos de açúcar no total comercializado merecem destaque entre esses fatores.

O perfil do mercado importador brasileiro modificou-se ao longo do periodo analisado, indicando uma maior diversificação dos paises de destino do açúcar, principalmente no último quinquênio. A participação dos EUA e da ex-URSS no total de açúcar comercializado pelo Brasil diminuiu ao longo da década de 80 , embora em meados da década de 90 venha apresentando indícios de recuperação. Por outro lado, 
verificou-se um aumento significativo na participação dos países da África e da Ásia (principalmente do Oriente Médio). Esses países têm sido responsáveis pela absorção de aproximadamente $70 \%$ do total das exportações de açúcar brasileiras realizadas em período recente.

Essa alteração e diversificação do mercado importador brasileiro foi acompanhada de mudanças nas preferências pelos tipos de açúcar. Verificou-se um crescimento geométrico nas exportações de açúcar cristal a partir de 1991. No mesmo período, ocorreram modificações institucionais e estruturais também no contexto doméstico do setor, além do que, a região Centro-Sul passou a sobressair como o novo pólo exportador de açúcar.

De maneira geral, ainda entre os anos de 1990 e 1994, o Brasil consolidou a perda de participação no total importado pelo mercado sul-americano. Exceção a essa tendência foram os países que constituem o MERCOSUL, no qual o Brasil aumentou a participação como exportador de açúcar e cujas perspectivas podem ser favoráveis caso outros países do continente se associem a esse mercado comum.

De maneira geral, a literatura confirma os resultados encontrados na análise de "market-share" de que há uma tendência de redução na demanda de açúcar de paises importadores tradicionais, e, ao contrário, verifica-se o crescimento da demanda nos mercados no Sudeste asiático, Oriente Médio e África. $\mathrm{O}$ uso crescente de substitutos de açúcar na indústria do Japão, EUA e Canadá e a consequente redução no consumo do produto, podem acirrar a competição pelos mercados consumidores dos países em desenvolvimento, justamente naqueles onde o Brasil vem se expandindo.

No entanto, há uma tendência de que a médio e longo prazos, a importância relativa das exportações dessa commodity, na sua forma comercializada atualmente, venha a reduzir-se em favor do crescimento nas exportações dos produtos de maior valor adicionado, ou seja, produtos processados que contenham o açúcar, a exemplo do que já vem ocorrendo no Japão.

Cuba, apesar de ter sua participação nas exportações mundiais de açúcar reduzida de $25,18 \%$ para $18,72 \%$ entre os subperiodos analisados, ainda constitui-se num dos cinco maiores exportadores mundiais. Aparentemente, o decréscimo das exportações 
cubanas está relacionado apenas às variações na sua oferta para exportação, decorrentes de restrições na produção. Não se constatou alteração no nível de preferência dos tradicionais importadores de Cuba, o que lhe garante, portanto, a estabilidade em seus relacionamentos comerciais.

Os coeficientes de elasticidade de substituição não significativos verificados para Brasil/Cuba aliados aos resultados da análise de "market-share" sugerem que o Brasil não tem se apropriado dessa parcela que Cuba vem perdendo no mercado internacional. Os dados de "market-share" sugerem que os paises agrupados como "Resto do Mundo" são os prováveis beneficiários dessa perda, possivelmente a Austrália e a Tailândia que apresentaram expansão nas exportações de açúcar nesse mesmo periodo.

Verificou-se que o açúcar exportado pelo Brasil apresentou certo grau de substituição pelo açúcar originado de outros países exportadores, em relação ao mercado importador mundial como um todo, por exemplo, é o caso de Brasil e África do Sul. Tal fato pode sugerir um comportamento de competição via preços nesse mercado, principalmente porque se destacam como países que detém custos de produção competitivos.

No entanto, em alguns dos casos examinados há indicações da existência de diferenciação do açúcar conforme a origem das exportações. Essa diferenciação pode estar associada à preferência do mercado importador relacionada à localização geográfica, relacionamentos históricos, acordos preferenciais, fatores institucionais ou facilidade de crédito, entre outros. A elasticidade de substituição estimada para Brasil/Austrália, no caso do açúcar refinado, sugere a existência dessa diferenciação do mercado importador diante dos produtos exportados pelos dois paises.

A localização geográfica pode tornar-se um fator cada vez mais determinante na escolha dos fornecedores de açúcar. A Tailândia e a Austrália, segundo literatura, vem expandindo seus mercados consumidores de açúcar por vários países da Ásia. Além disso, esses exportadores destacam-se por apresentarem taxas positivas de crescimento das exportações, bem como custos de produção entre os mais baixos do 
mundo. Neste contexto, esses dois países podem vir a ser grandes competidores do Brasil nos mercado do Oriente Médio e da África.

Os dados de elasticidade de substituição para Brasil/Tailândia e Brasil/Austrália não indicaram a existência de competição ou mesmo de diferenciação, porém é importante lembrar da limitação das estimativas obtidas devido, principalmente, à carência de dados de exportação desagregados por destino. Há possibilidade de que o Brasil venha atuando em nichos de mercado diferentes dos dois países exportadores asiáticos, o que explicaria esse comportamento atípico da relação de preços e quantidades exportadas.

É importante salientar que para fazer frente aos novos exportadores competitivos atuantes no mercado, o País ainda deve continuar esforçando-se para reduzir os custos de comercialização e os chamados custos de transação, embora no âmbito produtivo o Brasil se apresente como um dos mais eficientes produtores de açúcar.

Quanto às limitações do trabalho realizado é importante atentar para o número relativamente restrito de observações utilizadas nas análises. Isso dificultou, por exemplo, a realização de testes envolvendo o uso de mais de uma defasagem das variáveis utilizadas nos modelos de elasticidade de substituição. No modelo de "marketshare", por exemplo, a análise do efeito competitividade que resulta de vários fatores de naturezas distintas pode ter sido prejudicada, uma vez que a importância das variáveis políticas e macroeconômicas não pode ser captada pelo estudo em função do contexto analítico utilizado.

Além disso, as pressuposições simplificadoras adotadas para viabilizar o uso dos modelos de "market-share" e de elasticidade de substituição, entre elas a da oferta mundial perfeitamente elástica, podem restringir o alcance dessas conclusões. No modelo de "market-share" destaca-se ainda o problema da agregação dos periodos e dos mercados, que certamente influenciaram nos resultados obtidos. 


\section{ANEXO I}


Custos de produção de açúcar nos principais paises exportadores e em grandes paises importadores (1994)

\begin{tabular}{lc}
\hline \multicolumn{1}{c}{ País/Estado } & Custo de produção \\
& (US\$/tonelada) \\
\hline São Paulo & 190 \\
Brasil (Centro-Sul) & 240 \\
África do Sul & 250 \\
Austrália & 270 \\
Brasil (Nordeste) & 300 \\
Tailândia & 310 \\
Argentina & 364 \\
Uruguai & 380 \\
UE & 480 \\
EUA & 525 \\
Paraguai & 595 \\
Japão & 850 \\
\hline Fonte: dados compilados de Landel Mills/Geplacea,citado por COPERSUCAR (1995), comunicação \\
pessoal. & \\
& \\
\hline
\end{tabular}




\section{REFERÊNCIAS BIBLIOGRÁFICAS}

ABBOTT, G.C. Sugar. London: Routledge, 1990. 396 p.

AGROANALYSIS. Rio de Janeiro, v. 15, n. 3, mar. 1995. 52p.

ALMEIDA, C.O; MESQUITA, T. C. Causalidade entre preços externos e quantidades exportadas de café do Brasil no mercado internacional - 1970 a 1989. Pesquisa e Planejamento Econômico, v. 25, n. 3, p. 527-540, dez. 1995.

BARROS, G. S. C. Economia da comercialização agrícola. Piracicaba: FEALQ, 1987. p. 237 - 241: Elasticidades e flexibilidades.

BARROS, W.J.; BRANDT, S.A.; REZENDE, A.M. et al. Análise econométrica dos mercados interno e de exportação de açúcar. Revista Ceres, v. 24 , n.135, p. 484496, set/out. 1977.

BASTOS FILHO, G. S. Cana-de-Açúcar. Safra 1995/96: panorama das exportações de açúcar. Agroanalysis, v.15, n. 10, p. 41-45, out.1995.

BORRELL, B. How a change in Brazil's sugar policies would affect the world sugar market. Washington: World Bank, 1991. 30p. (Working Papers).

BORRELL, B.; DUNCAN, R.C. A survey of the costs of world sugar policies. The World Bank Research Observer, v. 7, n.2, p. 171-194, jul. 1992.

BURNQUIST, H.L. Açúcar e álcool: safra 1996/97. Preços Agrícolas, v.10, n.117, p. 6-9, jul.1996.

BURNQUIST, H.L.; BACCHI, M.R.P. Um panorama do mercado internacional do açúcar. Preços Agrícolas, v. 8, n. 96, p. 4-6, set. 1994.

BURNQUIST, H.L.; BACCHI, M.R.P. Sazonalidade no Mercado de Açúcar. Preços Agrícolas, v.10, n.115, p.6-9, maio 1996a.

BURNQUIST, H.L.; BACCHI, M.R.P. Setor sucroalcooleiro: evolução recente e perspectivas no Brasil. In: FERREIRA FILHO, J.B.S. (Coord.). Tendências para 
o período de 1996-2000 de culturas de soja, cana-de-açúcar, café, citros, milho, arroz, feijão, batata e pastagens. Piracicaba: FEALQ; MANAH S/A, 1996b. p.5 1-29. (Relatório de Pesquisa).

BUZZANELL, P. The Japanese sweetener industry. Sugar Y Azucar, v.89, n.11, p.31-39, Nov. 1994.

CAMARGO NETO, P. Açúcar - resistindo à liberalização. Agroanalysis, v.16, n.7, p. 16-18, jul.1996.

CARTEIRA DE COMÉRCIO EXTERIOR. Exportação. Brasilia: CACEX, 1979-1988.

CARVALHO, F.C. Mercado de exportação de açúcar do Brasil: modelos de equilíbrio e desequilibrio e avaliação da política de estabilização. Relatório de Pesquisa IEA, n. $16 / 86$, p. $1-99.1986$.

CARVALHO, F.M.A. O comportamento das exportações brasileiras e a dinâmica do complexo agroindustrial. Piracicaba, 1995. 126p. Tese (Doutorado) - Escola Superior de Agricultura "Luiz de Queiroz"/Universidade de São Paulo.

CARVALHO, F.C.; YOSHII, R.J.; NOGUEIRA JR., S. Efeitos do Acordo Internacional do Açúcar sobre a participação brasileira em mercados importadores. Agricultura em São Paulo, v. 35, n. 1, p. 1-6, 1988.

CARVALHO, F.C.; NOGUEIRA JÚNIOR, S; YOSHII, R. J. et al. Análise da parcela brasileira no mercado internacional do cacau. Agricultura em São Paulo, v. 38, n. 1, p. 47-61, 1991.

CHINA'S changing role in the sugar market. Sugar Y Azucar, v. 89 , n. 11, p. 42, Nov. 1994.

DATANET - Agricommodities. Newsletter especializada em açúcar. Sugarnet. (e-mail: www. truenet.com.br/datanet). Maio 1996. (Internet)

DOAN, T. A. RATS: regression analysis of time series; user's manual. Evaston: Estima, 1992. 1v.

EID, F. Progresso técnico na agroindústria sucroalcooleira. Informações Econômicas, v. 26 , n. 5, p. 29-35, maio 1996.

FAO. SOFA 1995: software. Roma; 1995. 1 disquete.

FAO TRADE YEARBOOK, v. 35-45; 47-48. 1979-1994. 
FLEMING, J. M.; TSIANG, S.C. Changes in competitive strength and export shares of major industrial countries. Staff Papers International Monetary Fund, v. 5, p. 218-248, Aug. 1956.

FONTES, R. M. O.; FERRÃO, P. R. Competitividade da soja brasileira no mercado internacional. In: CONGRESSO BRASILEIRO DE ECONOMIA E SOCIOLOGIA RURAL, 28.; Florianópolis, 1990. Anais. Brasilia: SOBER, 1990. v. 1, p. 149-63.

FONTES, R. M. O; GRENNES, T; JOHNSON, P. Diferenciação de produtos e ajustamento defazado numa análise das exportações de grãos dos Estados Unidos.

Revista de Econometria, v. 9, n.2, p. 211-229, nov. 1989.

GARCIA, M.E.C.; SACRISTAN, C.R. America Latina en el nuevo entorno internacional. Comércio Exterior, v.45, n.8, p. 573-576, ago. 1995.

GAZETA MERCANTIL. Relatório açúcar e álcool. São Paulo, 30 maio 1995. p. B/13-15.

GAZETA MERCANTIL. Subsídios encarecem alimentos. São Paulo, 24 Setembro 1996. p. B-17.

HOFFMANN, R.; VIEIRA, S. Análise de regressão. São Paulo: Editora Hucitec, 1987. 379p.

HOMEM DE MELO, F. Estabilização de preços: exportáveis vs. domésticos. São Paulo: USP, Instituto de Pesquisas Econômicas, 1986. 69p.

INTERNATIONAL SUGAR ORGANIZATION (ISO). (e-mail: www. sugarinfo.co.uk) 1996. (Internet).

JANK, M.S. A revolução tecnológica e o papel da CEE no mercado de açúcar. Revista Brasileira de Comércio Exterior, v. 22, p. 30-34, mar./abr. 1989.

JOHNSON, P.R.; GRENNES, T.; THURSBY, M. Trade models with differentiated products. American Journal of Agricultural Economics, v. 61, n. 1, p. 120-127, 1979.

JOHNSTON, J. Econometric methods. 3. ed. New York: McGraw-Hill, 1984. 568p. 
KONANDREAS, P.; HURTADO, $\mathrm{H}$. Analysis of trade flows in the international wheat market. Canadian Journal of Agricultural Economics, v. 26, n. 3, p. 11-23, 1978.

LEAMER, E. E.; STERN, R. M. Quantitative international economics. Chicago: Aldine Publ., 1970. 209p.

LEMOS, J.J.S. Análise espectral de ciclos de comércio agrícola do Brasil. Viçosa, 1983. 186p. Tese (Doutorado) - Universidade Federal de Viçosa.

MEDEIROS, V.X.; TEIXEIRA, E.C. Competitividade das exportações de carnes bovina, suína e de frango dos paises do Mercosul no mercado internacional. In: CONGRESSO BRASILEIRO DE ECONOMIA E SOCIOLOGIA RURAL, 32, Brasilia, 1994. Anais. Brasília: SOBER, 1994. v.1, p. 545-563.

MORRISSET, I. Some uses of elasticity of substitution - a survey. Econometrica, v. 21, n. 1, p. 41-62, Jan. 1953.

NASTARI, P.M. Tecnologia, custos e competitividade no Mercosul: o caso do açúcar e do álcool. Estudos Avançados: Coleção Documentos. Série: A Integração Regional e o Mercosul, n. 3, p. 125-152, 1994.

NONNENBERG, M. J. B. Bloco de comércio e competitividade das exportações brasileiras. Texto para Discussão, IPEA, n. 334, 31p., abr. 1994.

PEREIRA FILHO, A. Vendas de automóveis a álcool despencam 76\%. Folha de São Paulo, 2 outubro 1995. p. 2-3.

RICHARDSON, J. D. Constant-market-shares analysis of export growth. Journal of International Economics, v. 1, p. 227-239, July 1971.

RICO, M. El contrato azucarero. In: SEMINARIO NACIONAL SOBRE COMERCIALIZACION INTERNACIONAL DEL AZUCAR, Piracicaba, 1992. Anais. Piracicaba: ESALQ; GEPLACEA, 1992. p.1-11.

RIGAUX, L. R. Market-share analysis applied to Canadian wheat exports. Canadian Journal of Agricultural Economics, v. 19, n. 1, p. 22-34, July 1971.

SAVAGE, I. R.; DEUTSCH, K.W. A statistical model of the gross analysis of transaction flows. Econometrica, v. 28, n. 3, p. 551-72, July 1960. 
SCHAUB, J. D. U.S. Peanut exports: a market-share analysis. Oil Crops Situation and Outlook Report, n. 13, p. 19-21, Apr. 1987.

SEMINÁRIO NACIONAL SOBRE COMERCIALIZACION INTERNACIONAL DEL AZUCAR, Piracicaba, 1992. Anais. Piracicaba: ESALQ; GEPLACEA. 1992. 1v.

SILVA, O.M. Elasticidade de substituição para o suco de laranja no mercado internacional. Revista de Economia e Sociologia Rural, v. 30, n. 2, p. 135-147, abr./jun. 1992.

STALDER, S.H.G.M.; BURNQUIST, H.L. A importância dos subprodutos da agroindústria sucroalcooleira. Preços Agrícolas, v. 9, n. 108, p. 8-9, out. 1995.

STALDER, S.H.G.M.; BURNQUIST, H.L. A Importância dos subprodutos da cana-deaçúcar no desempenho do setor agroindustrial. Revista de Economia e Sociologia Rural, v.34, n.2, julh/dez.1996. / no prelo/.

SUGAR developments in South East Asia. Sugar Y Azucar, v. 90, n. 11, nov. 1995.

SUGAR AND SWEETENER SITUATION AND OUTLOOK REPORT. Washington: USDA, set. 1994.

SUGAR Y AZUCAR. v. 91, n. 3, p. 16-23, mar.1996a.

SUGAR Y AZUCAR. v. 91, n.4, p. 14 -26, abr. 1996b.

SUGAR Y AZUCAR. v.91, n.10, p. 10;36-7, out. 1996c.

SUMA AGRICOLA \& PECUÁRIA. Rio de Janeiro, n. 318, p. 6, out. 1996.

SZMERCSÁNYI, T. O planejamento da agroindústria canavieira do Brasil (1930 1975). São Paulo: Hucitec; Campinas: Universidade Estadual de Campinas, 1979. 540p.

SZMRECSÁNYI, T. Concorrência e complementariedade no setor açucareiro. Caderno de Difusão de Tecnologia, v. 6, n. 2/3, p. 165-182, maio/dez. 1989.

VASCONCELOS, M. F. S. Competitividade do comércio internacional de soja. Piracicaba, 1994. 92p. Dissertação (Mestrado) - Escola Superior de Agricultura "Luiz de Queiroz", Universidade de São Paulo.

YARBROUGH, B.V. ; YARBROUGH, R. M. The world economy: trade and finance. 2. ed. Orlando: The Dryden Press, 1991. 758p. 